Argonne

ANL-20/35

\title{
Assessment of Potential Future Demands for Hydrogen in the United States
}

\author{
Energy Systems Division
}




\begin{abstract}
About Argonne National Laboratory
Argonne is a U.S. Department of Energy laboratory managed by UChicago Argonne, LLC under contract DE-AC02-06CH11357. The Laboratory's main facility is outside Chicago, at 9700 South Cass Avenue, Lemont, Illinois 60439. For information about Argonne and its pioneering science and technology programs, see www.anl.gov.
\end{abstract}

\title{
DOCUMENT AVAILABILITY
}

Online Access: U.S. Department of Energy (DOE) reports produced after 1991 and a growing number of pre-1991 documents are available free at OSTI.GOV (http://www.osti.gov/),

a service of the US Dept. of Energy's Office of Scientific and Technical Information.

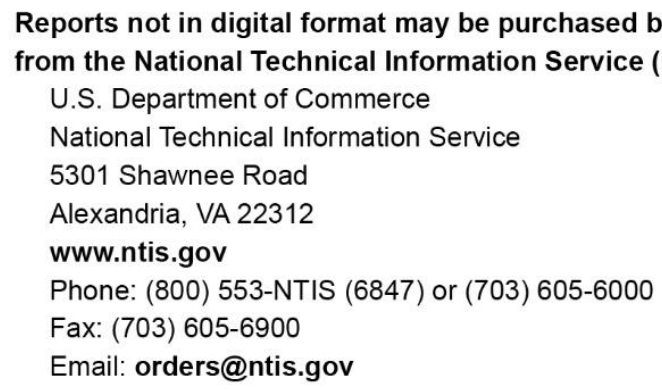

Reports not in digital format are available to DOE and DOE contractors from the Office of Scientific and Technical Information (OSTI):

U.S. Department of Energy

Office of Scientific and Technical Information

P.O. Box 62

Oak Ridge, TN 37831-0062

www.osti.gov

Phone: (865) 576-8401

Fax: (865) 576-5728

Email: reports@osti.gov

\begin{abstract}
Disclaimer
This report was prepared as an account of work sponsored by an agency of the United States Government. Neither the United States Government nor any agency thereof, nor UChicago Argonne, LLC, nor any of their employees or officers, makes any warranty, express or implied, or assumes any legal liability or responsibility for the accuracy, completeness, or usefulness of any information, apparatus, product, or process disclosed, or represents that its use would not infringe privately owned rights. Reference herein to any specific commercial product, process, or service by trade name, trademark, manufacturer, or otherwise, does not necessarily constitute or imply its endorsement, recommendation, or favoring by the United States Government or any agency thereof. The views and opinions of document authors expressed herein do not necessarily state or reflect those of the United States Government or any agency thereof, Argonne National Laboratory, or UChicago Argonne, LLC.
\end{abstract}




\section{Assessment of Potential Future Demands for Hydrogen in the United States}

by

Amgad Elgowainy ${ }^{1}$, Marianne Mintz ${ }^{1}$, Uisung Lee ${ }^{1}$, Thomas Stephens ${ }^{1}$, Pingping Sun ${ }^{1}$, Krishna Reddi ${ }^{1}$, Yan Zhou', Guiyan Zang ${ }^{1}$, Mark Ruth², Paige Jadun², Elizabeth Connelly², and Richard Boardman ${ }^{3}$

${ }^{1}$ Energy Systems Division, Argonne National Laboratory

${ }^{2}$ National Renewable Energy Laboratory

${ }^{3}$ Idaho National Laboratory

October 2020 



\section{CONTENTS}

ABBREVIATIONS AND ACRONYMS ……………….......................................................

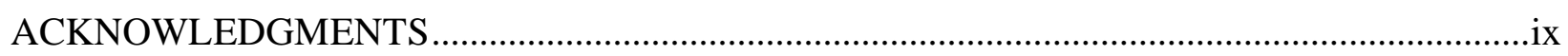

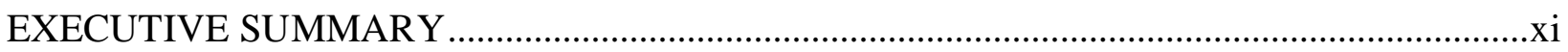

ES.1 Upgrading Oil/Biomass .....................................................................................

ES.2 Ammonia/Fertilizer ............................................................................................

ES.3 Synthetic Fuels and Chemicals................................................................................

ES.4 Injection of Hydrogen into NG Pipelines .......................................................................xvi

ES.5 Metals Production (Direct Reduction of Iron for Steelmaking) .................................. xvii

ES.6 Hydrogen Fuel Cell Vehicles ................................................................................. xviii

ES.7 Summary .....................................................................................................

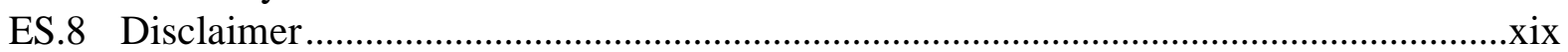

ES.9 References....................................................................................................

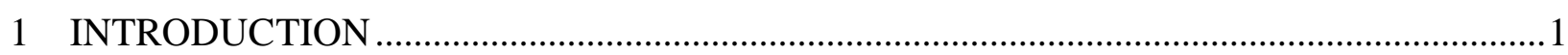

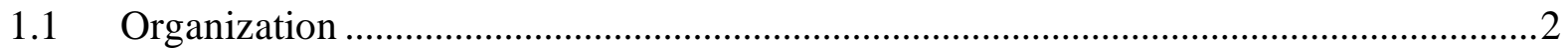

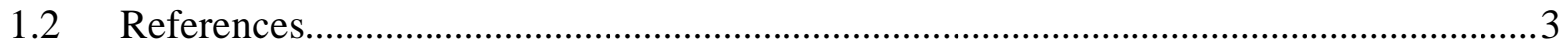

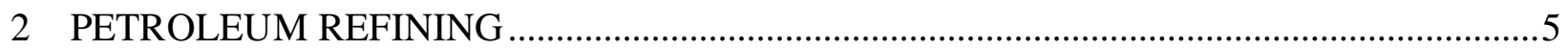

2.1 National Hydrogen Demand for Petroleum Refining ....................................................

2.2 Regional Hydrogen Demand for Petroleum Refining ………...................................10

2.2.1 PADD-level Analysis ..............................................................................10

2.2.2 Facility-level Analysis .............................................................................13

2.2.3 Regional Demand ..................................................................................13

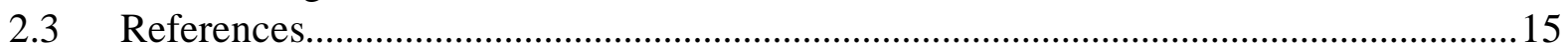

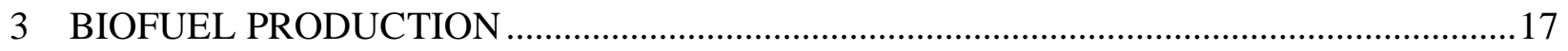

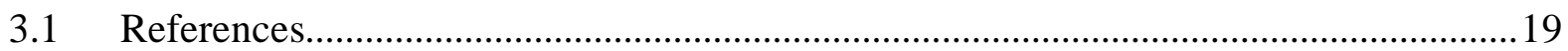

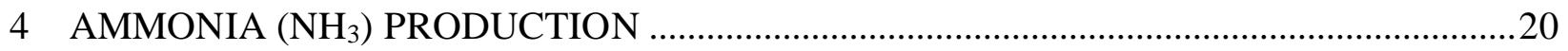

4.1 National Hydrogen Demand for Ammonia Production ………………………..............22

4.2 Regional Hydrogen Demand for Ammonia Production ...............................................2.

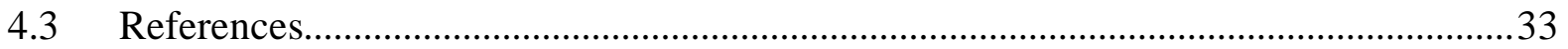

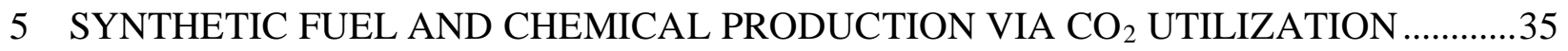

5.1 Potential Hydrogen Demand for U.S. Methanol Production .............................................37

5.2 Potential Hydrogen Demand for U.S. Synthetic Fuel and Chemical Production ..........40

5.3 Estimates of Threshold Hydrogen Price for Production of Various Synfuels................40

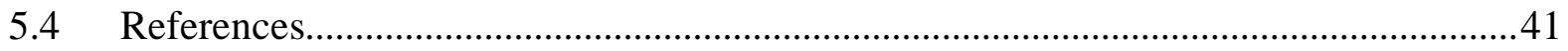

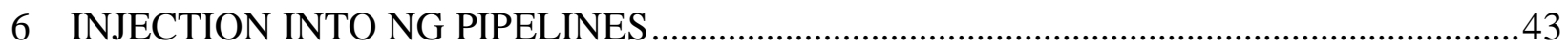

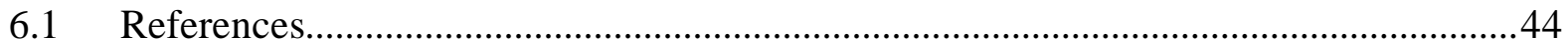

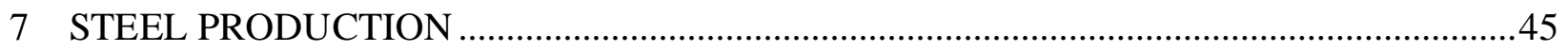

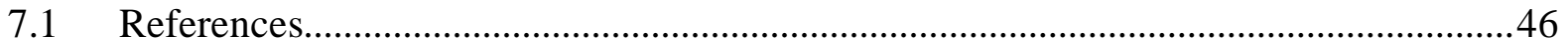




\section{CONTENTS (CONT.)}

8 LIGHT-DUTY VEHICLE (LDV) APPLICATIONS .........................................................4 48

8.1 Market Penetration and Stock of FCEVs in U.S. LDV Markets ..................................48

8.2 Total Light-Duty FCEV Hydrogen Use..................................................................50

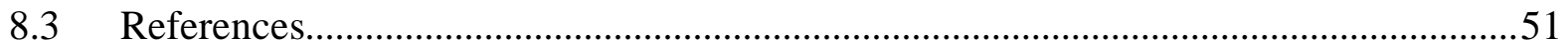

9 MEDIUM- AND HEAVY-DUTY TRUCK APPLICATIONS …......................................52

9.1 Vehicle Fuel Economy Modeling ….........................................................................53

9.2 Potential Hydrogen Demand by Medium- and Heavy-Duty Fuel Cell Vehicles ..........54

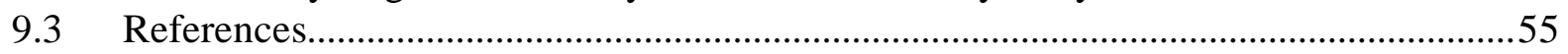

\section{FIGURES}

ES.1 Schematic of H2@ Scale Supply Sources and Demand Applications................................xi

ES.2 Projected Total Hydrogen Demand for U.S. Refineries by PADD through 2050 ........... xiii

ES.3 Projected Hydrogen Demand for U.S. $\mathrm{NH}_{3}$ Production through 2024 ............................xiv

ES.4 Hydrogen Demand for Synfuel Using $\mathrm{CO}_{2}$ from Ethanol, Refinery $\mathrm{H}_{2}$, and

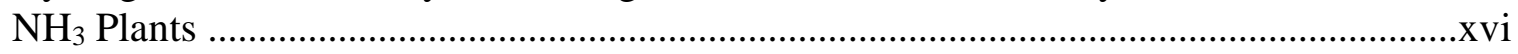

1.1 Schematic of H2@ Scale Supply Sources and Demand Applications................................1

2.1 Hydrogen Supply and Demand for Major Processing Units in 43 Refineries ....................5

2.2 Hydrogen Demand in Refineries: (1) Imported (Merchant) Hydrogen,

(2) Internal Hydrogen Produced from NG, and (3) By-product Hydrogen

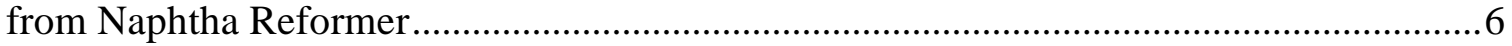

2.3 Steps in Assessing Hydrogen Demand by Petroleum Refineries.....................................6

2.4 Projections of Crude Input and Gasoline, Diesel, and Jet Fuel Production.........................7

2.5 Projections of Crude Oil's API Gravity and S Content ..................................................

2.6 Comparison of Hydrogen Intensity Estimated by the Regression Function with the Actual Hydrogen Intensity Samples .............................................................

2.7 Projection of Hydrogen Intensity Estimated by the Regression Function Using the Crude API Gravity and S Content and G/D Ratio for the Baseline

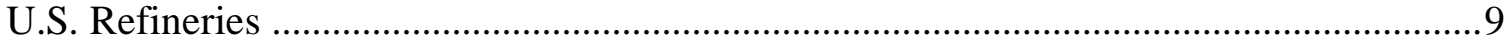

2.8 Projection of Hydrogen Demand by U.S. Refineries through 2050 ................................ 10

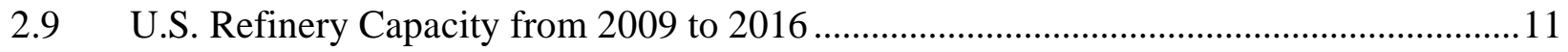

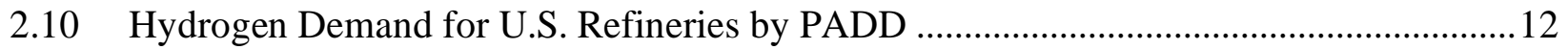

2.11 Hydrogen Demand Intensity in the United States and by PADD .................................... 12

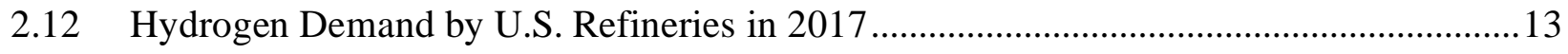




\section{FIGURES (CONT.)}

2.13 Projected Hydrogen Demand Intensity by PADD through 2050 .................................... 14

2.14 Projected Total Hydrogen Demand for U.S. Refineries by PADD through 2050 .............15

3.1 Conceptual Approach for Assessing Hydrogen Demand for Biofuel Production .............17

4.1 Steps in Hydrogen Demand Assessment for $\mathrm{NH}_{3}$ Production.........................................21

$4.2 \quad$ U.S. Agricultural Production by Commodity ................................................................21

4.3 Historic Yields of Agricultural Commodities ..............................................................22

4.3 Historic Yields of Agricultural Commodities ............................................................23

4.4 Projection of $\mathrm{NH}_{3}$ Demand by Crops and Other Applications........................................25

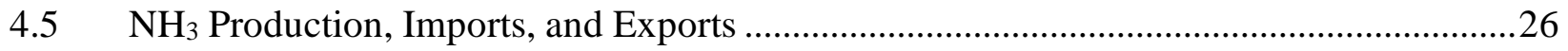

4.6 Price of $\mathrm{NH}_{3}$ and Corn in the United States, and Price of NG by World Region .............27

4.7 Net Import Reliance of U.S. $\mathrm{NH}_{3}$ Production and U.S. NG Industrial Price ....................28

4.8 Current and Projected Hydrogen Demand for U.S. $\mathrm{NH}_{3}$ Production................................29

4.9 Estimated Hydrogen Demand for U.S. $\mathrm{NH}_{3}$ Production in 2017 .....................................30

4.10 Types of Nitrogen Fertilizers Used in the United States ................................................30

4.11 U.S. Consumption of Nitrogen Fertilizers and Shares by Type in 2014 .........................33

5.1 Sources of Concentrated $\mathrm{CO}_{2}$, and Current Supply and Demand of Merchant $\mathrm{CO}_{2} \ldots \ldots . . .35$

5.2 Potential Hydrogen Demand for Synfuel Production Using $\mathrm{CO}_{2}$ from Ethanol,

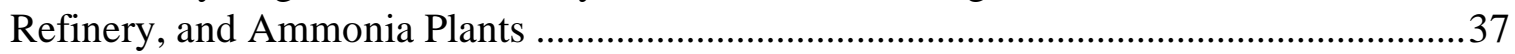

5.3 Global Methanol Applications and Demand Shares in 2010 and 2015 ..........................38

5.4 Current and Under Construction U.S. Methanol Plants ....................................................39

\section{TABLES}

ES.1 FCEV Market Shares and Stock at Market Equilibrium ........................................... xviii

ES.2 Summary of Hydrogen Demand Potential in 2050 for Various Applications...................xix

3.1 N Fertilizer Application Rates for Energy Crops ......................................................... 18

4.1 Average N Fertilizer Application Rates Derived from the USDA NASS Database .........24

4.2 U.S. Plants' N Fertilizer Demands in 2011 Estimated by USDA and the

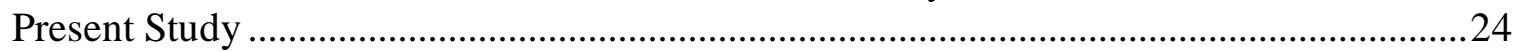

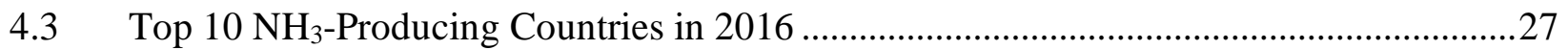

4.4 Properties, Market Shares, and Prices of N Fertilizers ....................................................31

$5.1 \quad$ U.S. $\mathrm{MeOH}$ Production and Potential Hydrogen and $\mathrm{CO}_{2}$ Demand through 2030 ...........39 


\section{TABLES (CONT.)}

8.1 Assumed Hydrogen Price at Dispenser in 2050 ........................................................49

8.2 FCEV Market Shares and Stock at Market Equilibrium .................................................49

8.3 Projected Light-Duty Vehicle Stock Penetration by Powertrain from MA3T ..................50

8.4 On-Road Fuel Economy of FCEV and ICEV Cars and Light Trucks

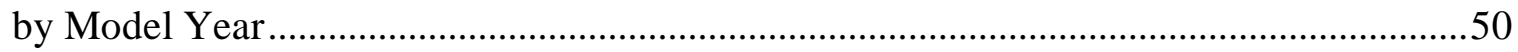

9.1 Parameters Relating to Fuel Efficiency of MHD Fuel Cell Trucks ..................................54 


\section{ABBREVIATIONS AND ACRONYMS}

AEO

API

Argonne

$\mathrm{CH}_{4}$

$\mathrm{CO}$

$\mathrm{CO}_{2}$

DME

DOE

DRI

E10

EIA

EPA

FC

FCC

FCET

FCEV

FIT

FOG

FT

G/D

GHG

GREET

GVWR

$\mathrm{H}_{2}$

HBI

HD

HEV

HFTO

$\mathrm{HHV}$

$\mathrm{HOF}$

HTE

ICEV

LD

LDT

LDV
Annual Energy Outlook

American Petroleum Institute

Argonne National Laboratory

methane

carbon monoxide

carbon dioxide

dimethyl ether

U.S. Department of Energy

Direct-reduced iron, direct reduction of iron

ethanol

U.S. Energy Information Administration

U.S. Environmental Protection Agency

fuel cell

fluid catalytic cracking

fuel cell electric truck

fuel cell electric vehicle

flash ironmaking technology

fats, oils, and greases

Fischer-Tropsch

gasoline-to-distillate

greenhouse gas

Greenhouse gas, Regulated Emissions and Energy use in Transportation

Gross Vehicle Weight Rating

hydrogen

hot briquetted iron

heavy-duty

hybrid electric vehicle

Hydrogen and Fuel Cell Technologies Office

higher heating value

high-octane fuel

high-temperature electrolysis

internal-combustion-engine vehicle

light-duty

light-duty truck

light-duty vehicle 
LPG

LTE

MA3T

MARPOL

MD

$\mathrm{MeOH}$

$\mathrm{M} / \mathrm{HD}$

MHDV

MMT

MPGGE

MT

MTBE

MTG

MTO

$\mathrm{N}$

NASS

$\mathrm{NG}$

$\mathrm{NH}_{3}$

NHTSA

NPV

$\mathrm{O} / \mathrm{O}_{2}$

P2G

PADD

PHEV

PHMSA

$\mathrm{R} \& \mathrm{D}$

S

SMR

synfuel

UAN

USDA

USGS

VMT liquefied petroleum gas

low-temperature electrolysis

Market Acceptance of Advanced Automotive Technologies

International Convention for the Prevention of Pollution from Ships

medium-duty

methanol

medium- and heavy-duty

medium/heavy-duty vehicle

million metric tons

miles per gallon gasoline equivalent

metric tons

methyl tert-butyl ether

methanol-to-gasoline

methanol-to-olefin

nitrogen

National Agricultural Statistics Service

natural gas

ammonia

National Highway Traffic Safety Administration

net present value

Oxygen

Power-to-Gas

Petroleum Administration for Defense District

plug-in hybrid electric vehicle

Pipeline and Hazardous Materials Safety Administration

research and development

sulfur

steam methane reforming/steam methane reformer

synthetic fuel

urea ammonium nitrate

U.S. Department of Agriculture

U.S. Geological Survey

vehicle miles traveled 


\section{ACKNOWLEDGMENTS}

This research effort was supported by the Hydrogen and Fuel Cell Technologies Office of the U.S. Department of Energy's Office of Energy Efficiency and Renewable Energy under Contract Number DE-AC02-06CH11357. The authors acknowledge Dr. Jeongwoo Han who led the petroleum refining and ammonia production analyses before departing from Argonne National Laboratory to join Exxon Mobile Corporation in 2018. The authors are grateful to Neha Rustagi and Fred Joseck from the U.S. Department of Energy's Hydrogen and Fuel Cell Technologies Office for their input, guidance and support. The authors thank Michael Berube, the acting Deputy Assistant Secretary for Transportation in the Office of Energy Efficiency and Renewable Energy, and Dr. Sunita Satyapal, the Director of the Hydrogen and Fuel Cell Technologies Office for their guidance and support. The authors owe special thanks to Dr. Marc Melaina and Dr. Marika Wieliczko for their support, careful review and valuable comments to improve the content of the report. The authors are grateful to the industry experts who reviewed the assumptions and results and provided valuable comments to this study. The authors also thank the H2@Scale team from multiple national laboratories for providing valuable input and comments throughout this project. The views and opinions of the authors expressed herein do not necessarily state or reflect those of the United States Government or any agency thereof. Neither the United States Government nor any agency thereof, nor any of their employees, makes any warranty, expressed or implied, or assumes any legal liability or responsibility for the accuracy, completeness, or usefulness of any information, apparatus, product, or process disclosed, or represents that its use would not infringe privately owned rights. 
This page intentionally left blank. 


\section{EXECUTIVE SUMMARY}

H2@Scale is a U.S. Department of Energy (DOE) initiative that brings together stakeholders to advance the affordable production, transport, storage, and utilization of hydrogen $\left(\mathrm{H}_{2}\right)$ as an energy carrier to increase revenue opportunities in multiple energy sectors. The focus of the current work is to characterize the growth potential of diverse hydrogen industries in the United States, given research and development (R\&D) advancements in hydrogen technologies.

Current and emerging hydrogen production technologies utilize diverse energy sources, including natural gas (NG) reforming, as well as renewable and nuclear power for lowtemperature and high-temperature water splitting. The produced hydrogen also enables emerging domestic industries that value conventional and renewable hydrogen as an energy carrier for intermediate and end use. The success of H2@Scale (Figure ES.1) depends not only on hydrogen demand from growing existing markets such as petroleum refining and ammonia $\left(\mathrm{NH}_{3}\right)$ production, but also on the development of new markets such as metals refining, synthetic fuel (synfuel) and chemical production, biofuels, light-duty (LD) and heavy-duty (HD) hydrogen fuel cell (FC) electric vehicles (FCEVs), and injection into NG pipelines, all of which can significantly increase hydrogen demand relative to current levels of approximately 10 million metric tons $[\mathrm{MMT}]$ annually.

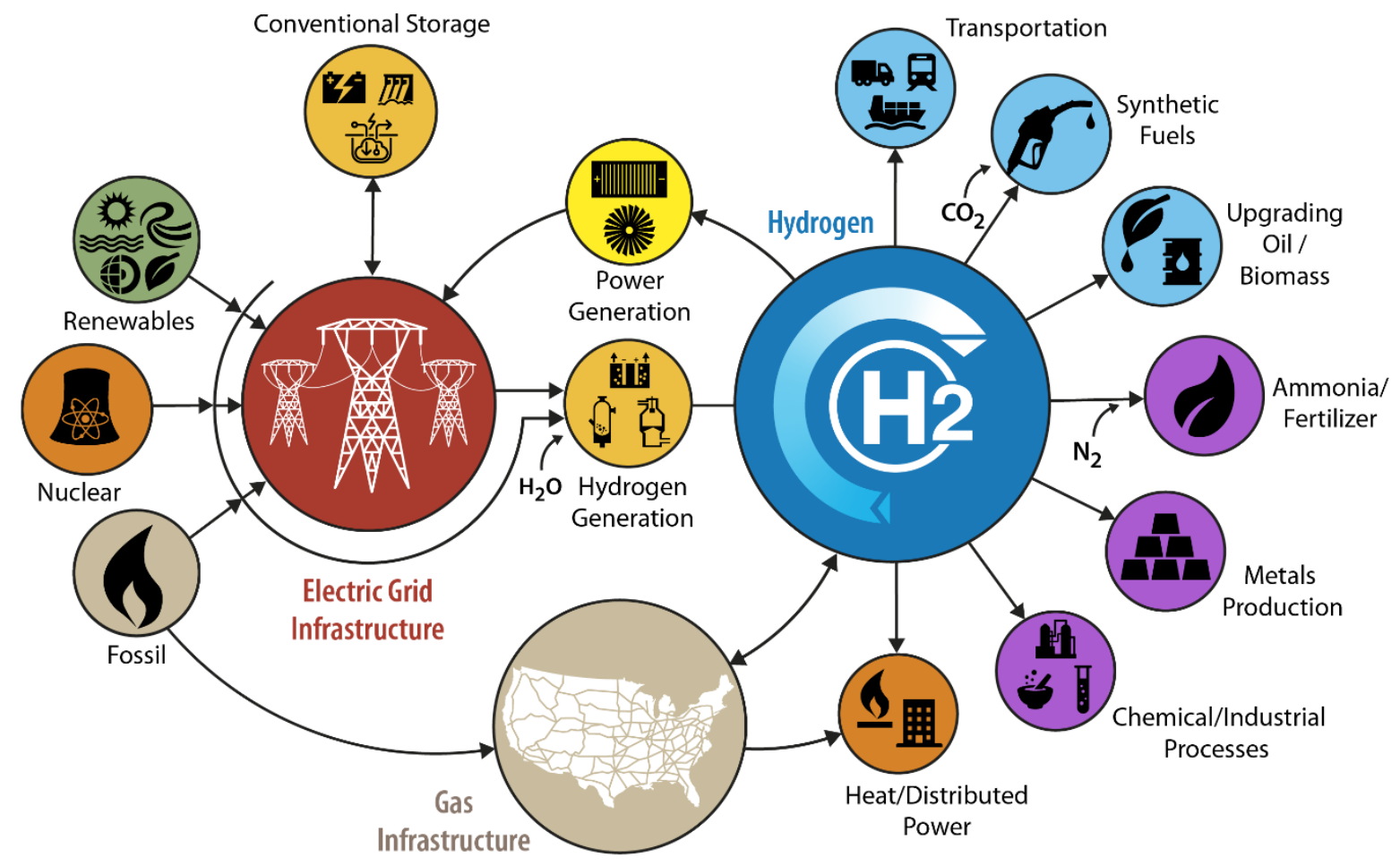

FIGURE ES.1 Schematic of H2@Scale Supply Sources and Demand Applications (Source: DOE 2020) 
This study focused primarily on five of the demand sectors shown on the right-hand side of Figure ES.1 - synfuels, upgrading of oil/biomass, $\mathrm{NH}_{3} /$ fertilizer, metals refining, and hydrogen vehicles (transportation) - along with gas infrastructure. ${ }^{1}$ For each sector, a hydrogen demand potential was quantified, along with a "threshold price." The hydrogen demand potential reflects a practical amount of hydrogen that could be used in that sector, barring economic considerations. The threshold price reflects the price at which the consumer would utilize hydrogen in lieu of an alternative that could supply the same performance.

The U.S. DOE's Hydrogen and Fuel Cell Technologies Office has been funding a number of stakeholder workshops, analytic studies and R\&D projects related to the H2@Scale concept. The present report provides details on the topic of potential hydrogen demand, while two additional analysis reports assess energy resources for hydrogen production (Connelly et al. 2020) and the technical and economic potential of the H2@Scale concept (Ruth et al. 2020). Demand potentials and threshold prices from the present report are used as inputs to the H2@Scale technical and economic potential report.

Potential demand for hydrogen was assessed for each sector by documenting current utilization and possible growth in existing hydrogen end uses and examining the potential for hydrogen use in new and emerging applications. While methodologies differed by sector, they shared a common objective of utilizing existing DOE- and industry-supported tools, data, and projections, and of capturing regional differences to the extent possible. Additional values of hydrogen as an energy storage medium that enables renewable power generation and provides a variety of electric grid services are discussed in a separate report (Ruth et al. 2020).

\section{ES.1 Upgrading Oil/Biomass}

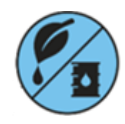

Today, petroleum refineries ("upgrading oil/biomass" in Figure ES.1) are the largest consumers of hydrogen in the United States, requiring about 10 MMT of hydrogen annually, of which about $60 \%$ is produced via steam methane reforming (SMR) of NG and $40 \%$ is produced internally via catalytic reforming of naphtha. Hydrogen demands by petroleum refineries depend largely on the volume of crude processed, product slates (e.g., the ratio of gasoline-to-diesel production), and the heaviness (measured by American Petroleum Institute [API] gravity) and sulfur (S) content of crude input. This study used DOE's U.S. Energy Information Administration (EIA) projections of crude input and gasoline, diesel, and jet fuel production through 2050, along with projections of crude API gravity and sulfur content from DOE's highoctane fuel study, to estimate growth in hydrogen demand through $2050 .^{2}$ Figure ES.2 shows

\footnotetext{
${ }^{1}$ Several demand sectors shown in Figure ES.1 are not included in this report, either because the application is not sufficiently well defined at this time or because it is spread over many different processes, complicating any assessment. These include heating and "other end uses." Because heating would be served from both, hydrogen supply and the gas infrastructure, assessing hydrogen demand is highly dependent on the concentration of hydrogen in the pipeline infrastructure and the ability of end-use devices to burn such a fuel. These issues are discussed in Section 6. Though excluded from this report, other end uses may be evaluated in future work.

${ }^{2}$ Hydrogen demand could increase further, depending on how refiners choose to comply with emissions reductions required under the International Convention for the Prevention of Pollution from Ships (MARPOL). Because of
} 
hydrogen demand by Petroleum Administration for Defense District (PADD) regions. In addition to the internal hydrogen production via catalytic reforming of naphtha, the total hydrogen demand for petroleum refining grows from 5.9 MMT in 2017 to an estimated 7.5 MMT in 2050.

This study also assessed potential hydrogen demand for biofuel production using EIA projections of jet fuel demand in 2050 (38.6 Billion gal) (EIA 2017) and assuming the American Society for Testing and Materials (ASTM) allowance of up to 50\% biofuel blending for aviation applications (ASTM 2020). Furthermore, the study estimated hydrogen demand for converting a projected 1.8 billion gal/yr of diesel drop-in fuels from the hydrotreatment of fats, oils, and greases (FOGs). Total hydrogen demand for biofuel production was then estimated by multiplying the hydrogen demand for selected biofuel conversion technologies per unit of fuel produced (or hydrogen intensity) with the estimated biofuel production volume. At $490 \mathrm{~g}_{\mathrm{H} 2} / \mathrm{gal}$ of bio-jet produced via catalytic fast pyrolysis of woody biomass, and $76 \mathrm{~g}_{\mathrm{H} 2} / \mathrm{gal}$ of diesel produced via hydrotreatment of FOGs, the total potential $\mathrm{H}_{2}$ demand for biofuel production is projected to be $8.7 \mathrm{MMT} / \mathrm{yr}$.

We assumed that hydrogen production costs via the refining of petroleum oil and bio-oil are competitive with the cost of hydrogen production via SMR of NG, and that hydrogen demand for refining processes will likely be inelastic relative to the hydrogen market price.

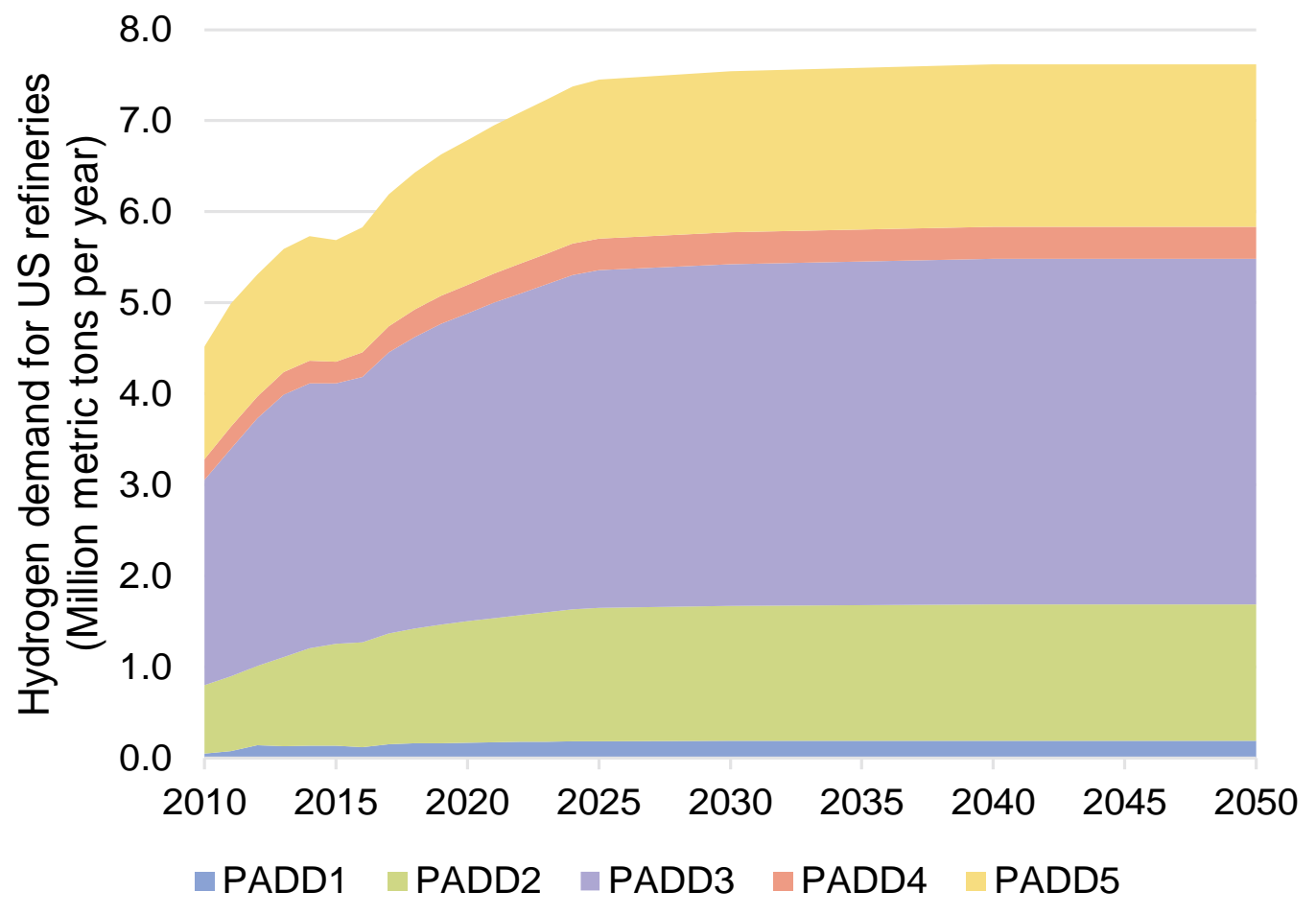

FIGURE ES.2 Projected Total Hydrogen Demand for U.S. Refineries by PADD through 2050

the uncertainty around that decision (and the potential for individual refiners to choose alternative solutions), MARPOL impacts were excluded from this analysis. 


\section{ES.2 Ammonia/Fertilizer}

Nitrogen $(\mathrm{N})$ fertilizers are an integral part of food- and energy-crop production and rely on $\mathrm{NH}_{3}$ production. Stoichiometrically, the $\mathrm{NH}_{3}$ synthesis process requires approximately $0.18 \mathrm{~kg}$ of hydrogen per $\mathrm{kg}$ of $\mathrm{NH}_{3}$ produced. This study used projected growth in agricultural commodity production to estimate total U.S. demand for $\mathrm{NH}_{3}$ fertilizers, along with $\mathrm{N}$ fertilizer efficiencies (in lb crop/lb N) from the National Agricultural Statistics Service (NASS) of the U.S. Department of Agriculture and also estimates of the domestically produced share of fertilizer demand to estimate hydrogen use.

Out of the 13.6 MMT of $\mathrm{NH}_{3}$ consumed in the United States in 2016, the U.S. Geological Survey (2018) estimates that 9.8 MMT were produced domestically, while 3.8 MMT were imported. Thus, depending on the cost of domestically produced $\mathrm{NH}_{3}$ and global $\mathrm{NH}_{3}$ prices, the U.S. may import or export $\mathrm{NH}_{3}$ and its derivatives. Because $\mathrm{NH}_{3}$ prices closely follow $\mathrm{NG}$ prices, the large resources and low prices of NG in the United States could play an important role in increasing domestic $\mathrm{NH}_{3}$ production for the export market, thus increasing demand for hydrogen as well. At the same time, if currently imported $\mathrm{NH}_{3}$ were instead produced in the United States, domestic production could be increased by approximately $30 \%$ without a corresponding increase in domestic $\mathrm{NH}_{3}$ demand.

Industry data on existing and planned $\mathrm{NH}_{3}$ plants in the United States were used to estimate the input hydrogen required for $\mathrm{NH}_{3}$ production by region (Ammonia Industry 2018). Figure ES.3 shows an estimated 25\% increase in hydrogen demand for $\mathrm{NH}_{3}$ production between 2017 and 2024. We assumed that domestic hydrogen demand for $\mathrm{NH}_{3}$ production beyond 2024 would grow by another $15 \%$ by 2050 , thus increasing annual hydrogen demand to $3.6 \mathrm{MMT}$. We also assumed that if hydrogen were produced at $\$ 2 / \mathrm{kg}$, domestic ammonia production would be competitive with imports and could even displace imports. While the current cost of state-of-theart SMR can reach lower levels due to low-priced natural gas, $\$ 2 / \mathrm{kg}$ was assumed to be a reasonable threshold price, given industry input on common price points for hydrogen.

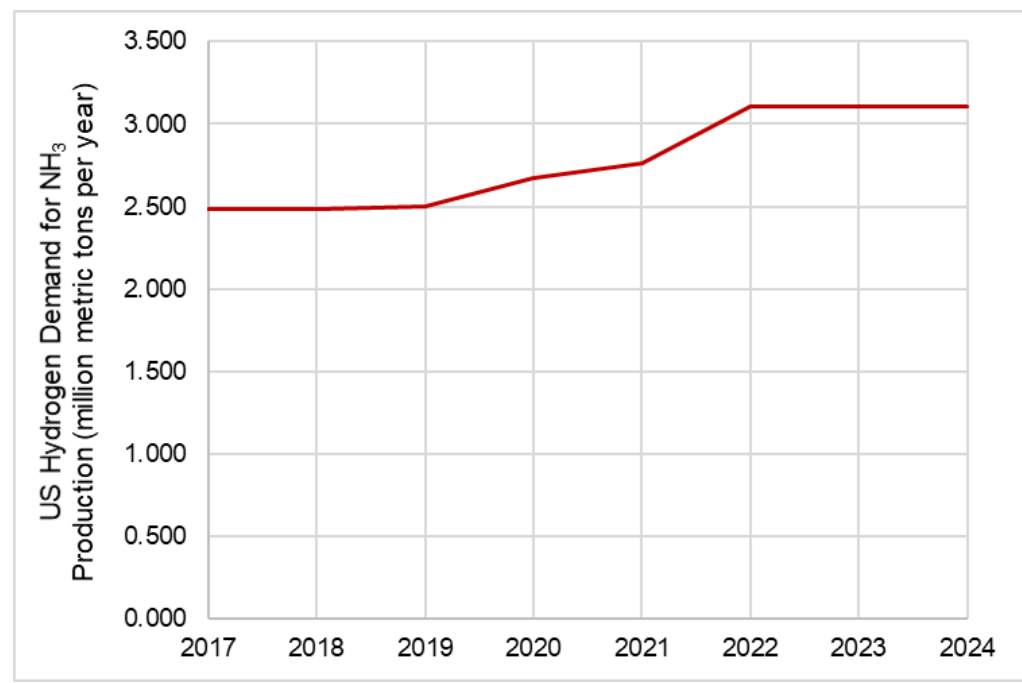

FIGURE ES.3 Projected Hydrogen Demand for U.S. $\mathrm{NH}_{3}$ Production through 2024 


\section{ES.3 Synthetic Fuels and Chemicals}

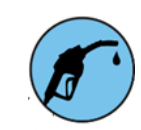

In 2016, the United States emitted 5 billion metric tons (MT) of carbon dioxide $\left(\mathrm{CO}_{2}\right)$. Because a large number of hydrocarbon synfuels and chemicals can be produced when hydrogen reacts with $\mathrm{CO}_{2}$, the production of synfuels and chemicals represents another potential demand for hydrogen. Moreover, when $\mathrm{CO}_{2}$ is captured and used for hydrocarbon synfuel production instead of being released to the atmosphere, the carbon in the produced fuel or chemical can be considered neutral in terms of emissions. Because of their high volumetric and gravimetric energy density, as well as their compatibility with existing fueling infrastructure, liquid hydrocarbon fuels are of particular interest for aviation, marine, rail, and truck applications. Methanol $(\mathrm{MeOH})$ production for domestic use and export markets is another potential growth opportunity.

Capturing $\mathrm{CO}_{2}$ from diluted flue gases is costly and requires a significant amount of energy. However, approximately 100 MMT of U.S. annual $\mathrm{CO}_{2}$ emissions already occur in concentrated form - from ethanol plants and from SMRs producing hydrogen for petroleum refining or $\mathrm{NH}_{3}$ production. If all $100 \mathrm{MMT}$ of $\mathrm{CO}_{2}$ from ethanol, $\mathrm{NH}_{3}$, and SMR plants were used to produce synfuels, the potential hydrogen demand could be as high as $14 \mathrm{MMT} / \mathrm{year}$, assuming a maximum $100 \%$ carbon conversion efficiency and using a stoichiometric $3: 1 \mathrm{H}_{2} / \mathrm{CO}_{2}$ molar ratio. Figure ES.4 shows the regional distribution of this potential hydrogen demand.

In the present study, a stoichiometric $3: 1 \mathrm{H}_{2} / \mathrm{CO}_{2}$ mole ratio and carbon conversion efficiency of $80 \%$ were used to estimate the potential hydrogen demand for methanol production, whereas a 2.4:1 $\mathrm{H}_{2} / \mathrm{CO}_{2}$ mole ratio and carbon conversion efficiency of $46 \%$ were used to estimate the potential hydrogen demand for synthetic Fischer-Tropsch (FT) fuel production. If only high-purity $\mathrm{CO}_{2}(\sim 44 \mathrm{MMT})$ from ethanol plants were converted to near-carbon-neutral synthetic FT fuels or synthetic methanol, the former would require approximately 5 MMT of hydrogen to produce approximately 2.3 billion gallon of FT fuel, whereas the latter would require about $6 \mathrm{MMT}$ to produce $25.5 \mathrm{MMT}$ of synthetic methanol.

A literature review of techno-economic analyses that estimate the cost of various synfuels and chemical production processes was conducted to estimate a target hydrogen price for these synthetic products that would enable them to be competitive with their conventional counterparts. The target hydrogen price was estimated so that the cost of synfuel would match the market price of its conventional counterpart. The threshold hydrogen price of $\sim \$ 1 / \mathrm{kg}$ was estimated as required to enable synthetic FT fuel to compete with petroleum diesel at $\$ 4 / \mathrm{gal}$. For synthetic $\mathrm{MeOH}$ production, the threshold hydrogen price was estimated at $\$ 1.73 / \mathrm{kg}$ to produce methanol at $\$ 0.5 / \mathrm{kg}$. 


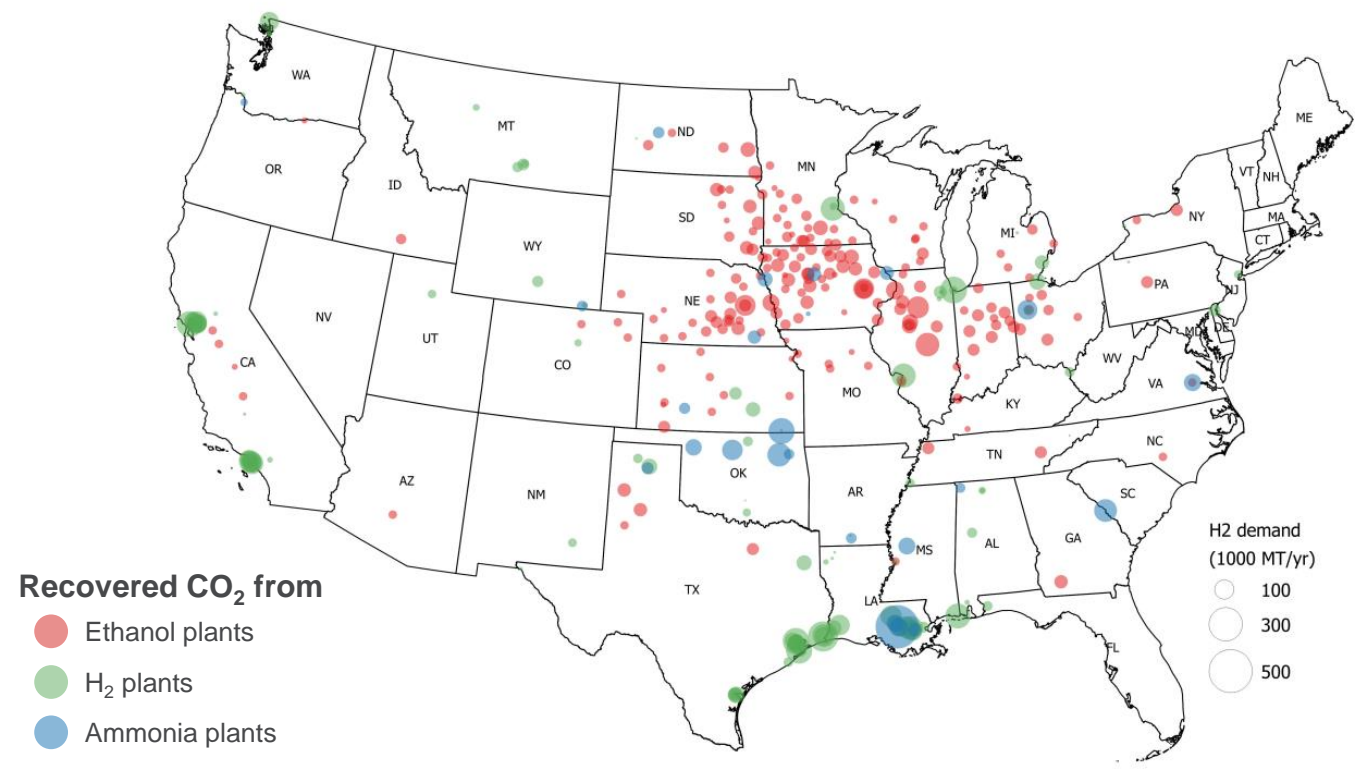

FIGURE ES.4 Hydrogen Demand for Synfuel Using $\mathrm{CO}_{2}$ from Ethanol, Refinery $\mathrm{H}_{2}$, and $\mathrm{NH}_{3}$ Plants

\section{ES.4 Injection of Hydrogen into NG Pipelines}

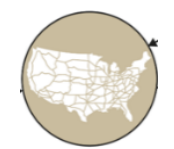

One economic option for rapidly expanding hydrogen delivery infrastructure is to utilize existing NG delivery infrastructure to receive hydrogen as a blending component. Converting NG pipelines to carry a blend of NG and hydrogen (up to $20 \%$ hydrogen) may require only modest modifications to transmission pipelines and end-use applications (Melaina et al. 2013). However, converting existing NG pipelines to deliver pure hydrogen may require more substantial modifications to end uses. Injection of hydrogen for blending also could allow the resale of NG with a "renewable" component. The blended NG/hydrogen mixture could then be used as a combustion fuel, which would result in potential additional growth in hydrogen demand.

Adding hydrogen to the NG supply can affect pipeline material as well as end-use equipment operations and emissions, thus necessitating careful study. Further research and testing are needed to identify impacts to new and legacy customer end-use equipment (e.g., set points on existing equipment as related to Btu content). Manufacturers design end-use equipment (supplied via the NG network) with relatively tight limits on Btu content, gas quality, etc., to promote safety and efficiency. Converting and redesigning equipment for higher blends of hydrogen in NG could be costly.

Injection of $20 \%$ (by volume) hydrogen into NG pipelines could create a daily demand of 44,000 MT of hydrogen in 2050 (or 16 MMT annually). However, given the absent incentives for zero-carbon hydrogen, its cost will be required to compete with that of NG on a heating value basis. EIA’s Annual Energy Outlook (AEO; EIA 2018) projects NG prices of \$5.88, \$6.48 and 
\$10.23 (2017 dollars) in 2050 per mmBtu (high heating value [HHV]) for industrial use for the Reference, High-Economic-Growth, and Low Oil and Gas Resource cases, respectively. These cases require a hydrogen price range of $\$ 0.8-\$ 1.4 / \mathrm{kg}$ to the end-user to be competitive with $\mathrm{NG}$ on an HHV basis.

\section{ES.5 Metals Production (Direct Reduction of Iron for Steelmaking)}

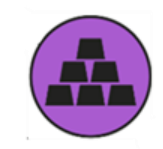

Traditionally, steel was produced via conversion of iron ore to pig iron in a blast furnace/coke oven, followed by conversion of the pig iron into steel in a basic oxygen $(\mathrm{O})$ furnace. However, in the U.S. iron production via blast furnace technology has been declining, whereas steel production via electric arc furnaces and facilities that employ direct reduction of iron (DRI) using syngas (a mixture of hydrogen and carbon monoxide [CO] produced from NG) has been growing. DRI plants are more scalable and sustainable than blast furnaces, and also provide the virgin feedstock needed for electric arc furnaces. DRI manufacturers have expressed interest in replacing up to $30 \%$ of NG with zero-carbon hydrogen. Recently, Midrex Technologies, Inc., built a DRI plant in Texas with annual hot briquetted iron (HBI) capacity of 2 million tons, using a syngas mixture of $55 \%$ hydrogen and $36 \% \mathrm{CO}$ (using NG) as the reductant. Midrex is also building another DRI plant in Ohio with an annual HBI capacity of 1.6 million tons.

In 2017, U.S. steel consumption was 106.2 MMT, while production was 81.6 MMT (i.e., imports accounted for $34.6 \mathrm{MMT}$ or $32.6 \%$ of consumption). Based on trends in U.S. iron ore production, imports, and exports, we estimate that $68 \%$ of the $81.6 \mathrm{MMT}$ of U.S. steel production was in electric arc furnaces (i.e., only $32 \%$ was produced in basic oxygen furnaces).

The mass of hydrogen required to fully reduce $1 \mathrm{MT}$ of iron ore ranges from 0.08 to 0.12 MT, depending on the technology employed, reaction temperature, and the reaction off-gas available for hydrogen preheating. Hydrogen price affects economic feasibility more strongly than the capital and operating costs of the DRI process. It is estimated that a hydrogen price of $\$ 1.7 / \mathrm{kg}$ would generate a positive net present value (NPV) for the DRI technology.

EIA's Annual Energy Outlook (EIA 2018) projects crude steel production growing to approximately $120 \mathrm{MMT}$. If all this production were converted to DRI technology using lowcost hydrogen (i.e., no blast furnace plants), the technical potential for hydrogen demand could be on the order of 12 MMT annually. If only $30 \%$ of the reductant gas mix were hydrogen, its demand for use in DRI plants would be on the order of 4 MMT. Thus, the annual hydrogen demand for DRI in 2050 could be 4 MMT at a price of $\$ 1.7 / \mathrm{kg}$ for positive NPV, versus the full 12 MMT if hydrogen were price-competitive with NG on a thermal heating value basis (i.e., $\$ 0.8 / \mathrm{kg}$, assuming a natural gas price of \$5.88 [2017 dollars] per mmBtu [HHV] for industrial use using the AEO Reference case). 


\section{ES.6 Hydrogen Fuel Cell Vehicles}

Potential hydrogen demand for FCEVs was examined by vehicle type (i.e., cars and LD trucks or LDTs), which are collectively termed LD vehicles or LDVs, and medium-duty [MD] and HD vehicles, which are collectively termed MHDVs). For FCEVs, we estimated two hydrogen demand potentials: (1) a serviceable consumption potential, defined as the quantity of hydrogen that would be consumed to serve the portion of the market that could be captured without considering economics, which can be considered an upper bound for the size of the FCEV market, and (2) an economic potential, which is the quantity of hydrogen at defined price at which consumers are willing to buy FCEVs. Existing vehicle choice models, such as Market Acceptance of Advanced Automotive Technologies (MA3T), have shown that the penetration of FCEVs into the LDV fleet is particularly sensitive to hydrogen price. Within the vehicle choice modeling completed in this analysis, the retail price of hydrogen at the dispenser was assumed to reach $\$ 5.03 / \mathrm{kg}$, consistent with DOE cost target. Table ES.1 summarizes estimates for the future market penetration levels of FCEVs and for FCEV stocks in the LDV sector (cars and LDTs), that is, at market equilibrium (beyond 2050). This report estimates the corresponding total potential future hydrogen demand by light-duty FCEVs to be 11.7 MMT (4.3 MMT by cars and 7.4 MMT by light-duty trucks). The corresponding serviceable consumption potential for these vehicle classes is $21 \mathrm{MMT} / \mathrm{year}$.

FCEVs have a higher value proposition in zero-emission MHDVs as compared to LDVs given that their much larger energy storage potential enables them to satisfy both power and range requirements. However, since vehicle choice models for the MHDV sector are not yet well-established, in the current report we assumed the future market penetration rate of FC MHDVs to be consistent with that of FC LDVs (i.e., 22\% penetration). Using this value, our report finds a total potential future hydrogen demand of 5.2 MMT/year by FC MHDVs (1.4 MMT for MD trucks and 3.8 MMT for HD trucks). The corresponding serviceable consumption potential for these vehicle classes is $8 \mathrm{MMT} / \mathrm{year}$.

TABLE ES.1 FCEV Market Shares and Stock at Market Equilibrium

\begin{tabular}{|r|c|}
\hline \multicolumn{2}{|c|}{ FCEV Market Penetration at Equilibrium Assuming } \\
HFTO Technical Targets are Met
\end{tabular}




\section{ES.7 Summary}

The demand potential for hydrogen in 2050 for various applications is shown in Table ES-2. The threshold price depicts the price at which the application would utilize hydrogen in lieu of an alternative feedstock. The threshold price is estimated at the demand point for vehicles, at terminal for industrial processes, and at injection point for blending with natural gas.

TABLE ES.2 Summary of Hydrogen Demand Potential and Threshold Prices in 2050 for Various Applications

\begin{tabular}{|c|c|c|c|c|}
\hline Application & $\begin{array}{c}\text { Serviceable } \\
\text { Hydrogen } \\
\text { Consumption } \\
\text { Potential [MMT] }\end{array}$ & $\begin{array}{c}\text { Hydrogen } \\
\text { Demand Potential } \\
\text { at Threshold Price } \\
{[\mathrm{MMT}]}\end{array}$ & $\begin{array}{c}\text { Threshold } \\
\text { Hydrogen Price } \\
{[\$ / \mathrm{kg}]}\end{array}$ & Notes \\
\hline Petroleum Refining & 7.5 & 7.5 & Inelastic demand & $\begin{array}{l}\text { No substitute for } \\
\text { hydrogen in refining } \\
\text { process }\end{array}$ \\
\hline Biofuels & 8.7 & 8.7 & Inelastic demand & $\begin{array}{l}50 \% \text { of jet fuel demand } \\
\text { in } 2050 \text { from biofuels }\end{array}$ \\
\hline Ammonia & 2.5 & 2.5 & Inelastic demand & $\begin{array}{l}\text { Demand for current } \\
\text { production of } \mathrm{NH}_{3}\end{array}$ \\
\hline Ammonia & 1.1 & 1.1 & 2 & $\begin{array}{l}\text { Price competitive with } \\
\text { imported ammonia }\end{array}$ \\
\hline Synthetic Methanol & 6 & 6 & 1.73 & $\begin{array}{l}\text { Price competitive with } \\
\text { imported methanol }\end{array}$ \\
\hline $\begin{array}{l}\text { Synthetic Methanol- } \\
\text { to-Gasoline }\end{array}$ & 8 & 8 & $<1$ & $\begin{array}{l}\text { Price competitive with } \\
\text { petroleum gasoline }\end{array}$ \\
\hline $\begin{array}{l}\text { Injection to NG } \\
\text { Infrastructure }\end{array}$ & 16 & 16 & 0.8 & $\begin{array}{l}\text { Price competitive with } \\
\text { natural gas, based on } \\
\text { HHV }\end{array}$ \\
\hline $\begin{array}{l}\text { Iron Reduction and } \\
\text { Steelmaking }\end{array}$ & 4 & 4 & 1.7 & $\begin{array}{l}\text { Price required to generate } \\
\text { positive NPV }\end{array}$ \\
\hline $\begin{array}{l}\text { Iron Reduction and } \\
\text { Steelmaking }\end{array}$ & 8 & 8 & 0.8 & $\begin{array}{l}\text { Price competitive with } \\
\text { natural gas in DRI plants }\end{array}$ \\
\hline $\begin{array}{l}\text { Light-Duty FCEVs } \\
\text { (cars) }\end{array}$ & \multirow{2}{*}{21} & 4.3 & 5 & \multirow{2}{*}{$\begin{array}{l}\text { Vehicle choice model } \\
\text { using Threshold price }\end{array}$} \\
\hline $\begin{array}{l}\text { Light-Duty FCEVs } \\
\text { (trucks) }\end{array}$ & & 7.4 & 5 & \\
\hline $\begin{array}{l}\text { Medium-Duty } \\
\text { FCEVs }\end{array}$ & \multirow[t]{2}{*}{8} & 1.4 & 5 & \multirow{2}{*}{$\begin{array}{l}\text { Market penetration } \\
\text { consistent with LDVs }\end{array}$} \\
\hline Heavy-Duty FCEVs & & 3.8 & 5 & \\
\hline
\end{tabular}

\section{ES.8 Disclaimer}

We note that the assessed scenarios for potential hydrogen demand by various applications may be exclusive of one another (i.e., the hydrogen demand by different scenarios may not be additive). For example, future hydrogen demand for petroleum refining may actually decrease if demand for hydrogen in FCEVs increases. In the estimation of the hydrogen demand potential, we assume that applications that see a decline due to growth in another sector will transition to export markets. A more rigorous analysis of competition between sectors was beyond the scope of this analysis. 


\section{ES.9 References}

Ammonia Industry, 2018. "Ammonia Capacity in North America." Available at https://ammoniaindustry.com/download-ammonia-capacity-in-north-america/, accessed July 12, 2020.

ASTM (American Society for Testing and Materials), 2020. Standard Specification for Aviation Turbine Fuel Containing Synthesized Hydrocarbons, ASTM D7566-20.

Connelly, Elizabeth, Michael Penev, Anelia Milbrandt, Billy Roberts, Nicholas Gilroy, and Marc Melaina. 2020. Resource Assessment for Hydrogen Production. Golden, CO: National Renewable Energy Laboratory. NREL/TP-5400-77198. Available at https://www.nrel.gov/docs/fy20osti/77198.pdf.

DOE (U.S. Department of Energy), 2020.H2@ Scale, Office of Energy Efficiency and Renewable Energy, Available at https://www.energy.gov/eere/fuelcells/h2scale, accessed July 13. 2020.

EIA (U.S. Energy Information Administration), 2018. Annual Energy Outlook 2018 with Projections to 2050, February 6. Available at https://www.eia.gov/outlooks/aeo/pdf/AEO2018.pdf, accessed July 13, 2020.

Melaina, M.W., O. Antonia, and M. Penev, 2013. Blending Hydrogen into Natural Gas Pipeline Networks: A Review of Key Issues, NREL/TP-5600-51995, Golden, CO: National Renewable Energy Laboratory. https://www.nrel.gov/docs/fy13osti/51995.pdf, accessed October 15, 2020.

Ruth, M.F., P. Jadun, N. Gilroy, E. Connelly, R. Boardman, A.J. Simon, A. Elgowainy, and J. Zuboy, 2020. The Technical and Economic Potential of the H2@Scale Concept within the United States. Golden, CO: National Renewable Energy Laboratory. https://www.nrel.gov/docs/fy21osti/77610.pdf.

USGS (U.S. Geological Survey), 2018. "Minerals Information: Nitrogen Statistics and Information.” Available at https://minerals.usgs.gov/minerals/pubs/commodity/nitrogen/, accessed July 12, 2020. 


\section{INTRODUCTION}

H2@Scale is a U.S. Department of Energy (DOE) initiative bringing together stakeholders to advance affordable large-scale hydrogen $\left(\mathrm{H}_{2}\right)$ production, transport, storage, and utilization to unlock revenue potential and value across sectors. The goal of the current project is to address the long-term demand potential for hydrogen in existing and future markets. ${ }^{3}$

Current and emerging hydrogen production technologies utilize diverse energy sources, including reformation of natural gas (NG) as well as solar and nuclear power for lowtemperature and high-temperature water splitting (Figure 1.1). While the primary markets for hydrogen are currently petroleum refining and ammonia $\left(\mathrm{NH}_{3}\right)$ production, emerging sectors have potential to significantly increase hydrogen demand. These sectors include synthetic fuel (synfuel) and chemical production, biofuels, injection into NG pipelines, and light-duty (LD) and heavy-duty (HD) hydrogen fuel cell (FC) electric vehicles (FCEVs), all of which can significantly increase hydrogen demand relative to the current levels of approximately 10 million metric tons [MMT] annually.

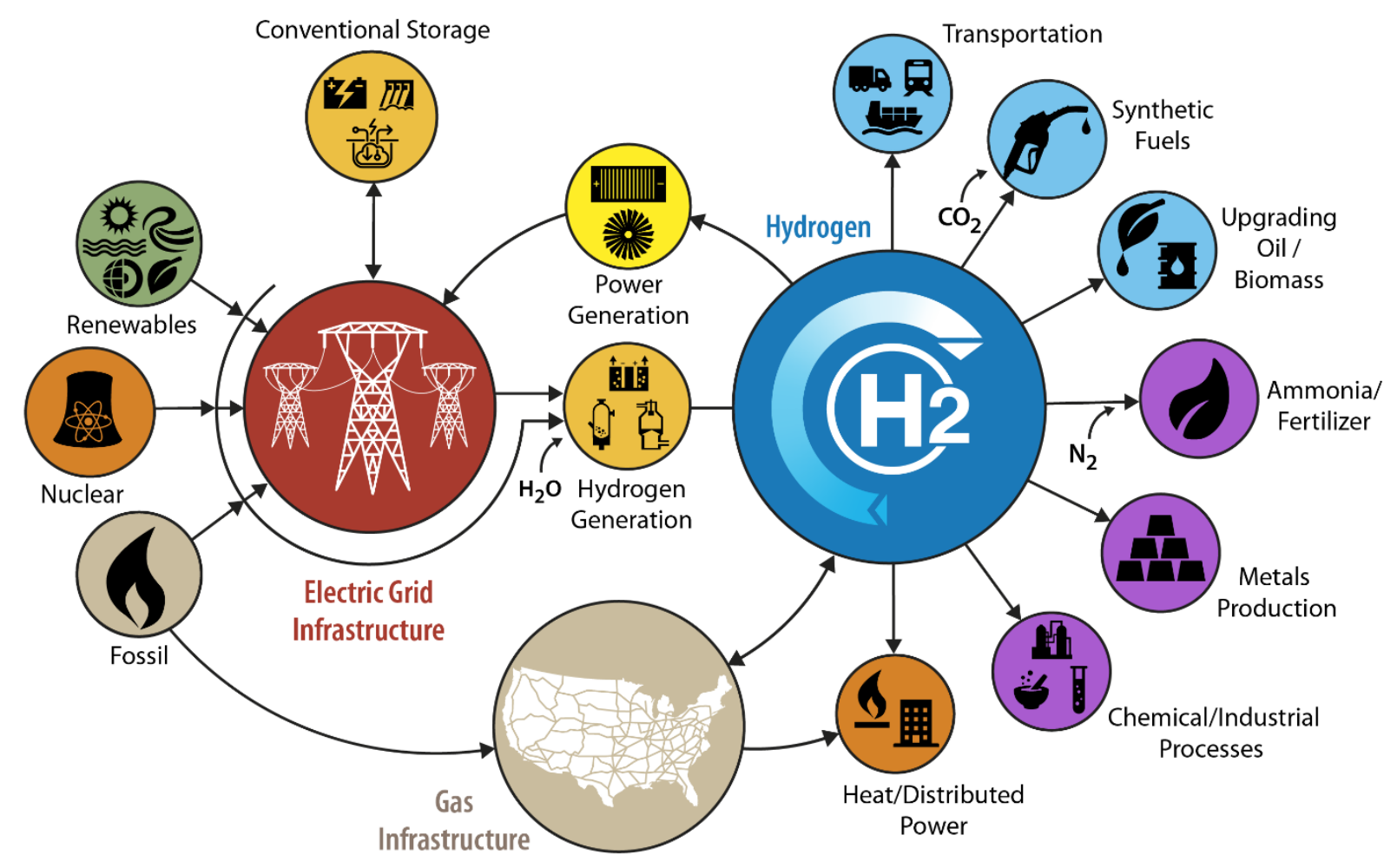

FIGURE 1.1 Schematic of H2@Scale Supply Sources and Demand Applications (Source: DOE 2020)

${ }^{3}$ A companion document summarizes potential supplies of hydrogen to serve these markets: Ruth, M.F., P. Jadun, N. Gilroy, E. Connelly, R. Boardman, A.J. Simon, A. Elgowainy, and J. Zuboy, 2020. The Technical and Economic Potential of the H2@Scale Concept within the United States. Golden, CO: National Renewable Energy Laboratory. 


\subsection{Organization}

This report is organized into nine sections. Following this introduction, eight sections focus on specific hydrogen demand sectors. Each sector is described in terms of current energy consumption, trends in consumption over time, and potential demand for hydrogen through 2050 .

Petroleum Refineries. Currently, U.S. petroleum refineries consume about 10 MMT of hydrogen annually, including byproduct hydrogen from naphtha reformer (Lee et al. 2017). Major hydrogen-consuming processes include hydrocracking, ultra-low-sulfur diesel hydrotreating, gas oil (fluid catalytic cracking [FCC] feed) hydrotreating, and naphtha hydrotreating. Hydrocrackers mainly produce diesel from crude heavy bottom cut, while hydrotreaters remove sulfur (S) from various feed, intermediate, and product streams. Thus, future hydrogen demands by petroleum refineries largely depend on the volume and quality of crude input, especially with respect to heaviness (American Petroleum Institute [API] gravity) and sulfur content, and the amount of diesel production. The global and domestic shift to clean fuels, such as by tightening sulfur specifications in fuels, will also increase hydrogen demand by oil refineries. Projections of crude input and quality, refinery product slates, and their impact on the potential growth of hydrogen demand by refineries through 2050 are presented in Section 2.

Biofuels. Increased production of biofuels could increase demand for hydrogen as a biorefinery input. Biofuel production requires hydrogen for conversion, followed by hydroprocessing and/or hydrotreating. The total hydrogen demand for biofuel production is calculated by multiplying the projected biofuel production volume with the hydrogen intensity required for each potential biofuel conversion process. Estimates of potential future hydrogen demand for biofuel production are presented in Section 3.

Ammonia Plants. $\mathrm{NH}_{3}$ is essential for the production of a wide variety of nitrogen (N) fertilizers. Currently, the United States uses about 2.5 MMT of hydrogen to produce $\mathrm{NH}_{3}$ (Ammonia Industry 2018). Future hydrogen demand for $\mathrm{NH}_{3}$ production will depend on growth in the volume, distribution, and type of agricultural production, as well as near-term and longterm changes in domestic $\mathrm{NH}_{3}$ production capacity. Potential growth in domestic $\mathrm{NH}_{3}$ production capacity and corresponding growth in hydrogen demand through 2050 are presented in Section 4.

Synthetic Fuels and Chemicals. A wide variety of synfuels and chemicals can be produced when hydrogen reacts with carbon dioxide $\left(\mathrm{CO}_{2}\right)$. Assessing future hydrogen demand requires identifying not only promising synfuels and chemicals, but also the size and location of concentrated supplies of $\mathrm{CO}_{2}$ such as ethanol (E10) and $\mathrm{NH}_{3}$ plants, steam methane reformers (SMRs), and petroleum refineries. The corresponding demand for input hydrogen to produce synthetic methanol $(\mathrm{MeOH})$ and liquid and gaseous hydrocarbons - as well as estimated threshold hydrogen prices for that production - are presented in Section 5. Section 5 also includes potential hydrogen demand for low-carbon, infrastructure-compatible, synthetic hydrocarbon fuels, such as Fischer-Tropsch (FT) diesel and FT jet fuel, to serve the off-road transportation sector. 
Pipeline Injection. One possibility for rapid expansion of hydrogen demand is to blend hydrogen for use in existing applications of natural gas. Preliminary estimates indicate that gaseous hydrogen can be injected into a natural gas pipeline network at concentrations of up to $20 \%$ by volume without substantial impact to end uses or pipeline material. The amount of hydrogen that can be injected into the NG pipeline network, associated issues and challenges, and the threshold price at which hydrogen competes with NG on a thermal Btu basis are presented in Section 6.

Steel Production. Direct reduction of iron (DRI) using syngas (a mixture of hydrogen and carbon monoxide [CO] produced from NG) has the potential to grow both, as a replacement for blast furnaces because it is more scalable and sustainable and as a technology to improve the feedstock to electric arc furnaces. DRI manufacturers are interested in the use of hydrogen blends in lieu of natural gas. Potential hydrogen demand for steel production is presented in Section 7.

Light-Duty Vehicles. This study evaluated potential future hydrogen demand for fuel cell LD vehicles (LDVs) under specific hydrogen price scenarios. Market penetration rates were developed using DOE cost and performance targets representing successful Hydrogen and Fuel Cell Technologies Office (HFTO) and Vehicle Technologies Office programs, and incorporating the U.S. Energy Information Administration's (EIA's) Annual Energy Outlook (AEO) forecasts of LDVs and fuel/energy prices, along with a vehicle choice model (the Market Acceptance of Advanced Automotive Technologies [MA3T]) developed by Oak Ridge National Laboratory and estimates of LDV fuel economy from Argonne National Laboratory's (Argonne's) vehicle simulation model, Autonomie (Argonne undated). Coupled with detailed modeling of vehicle survival, utilization, and fuel economy, the market penetration results were used to generate vehicle stock levels and hydrogen demand estimates using Argonne's VISION model (an agedependent survival and usage model). Estimates of potential future hydrogen demand by LDVs are presented in Section 8.

Medium- and Heavy-Duty Vehicles. For this study, we assumed that future market penetration of FC medium- or heavy-duty vehicles (MHDVs) will be consistent with that of FC LDVs, and we used Autonomie estimates of fuel economy and VISION estimates of stocks and vehicle miles traveled (VMT) to calculate potential hydrogen demand for each vehicle class. Estimates of potential future hydrogen demand by medium-duty (MD) and HD vehicles are presented in Section 9.

\subsection{References}

Ammonia Industry, 2018. "Ammonia Capacity in North America." Available at https://ammoniaindustry.com/download-ammonia-capacity-in-north-america/, accessed July 12, 2020.

Argonne (Argonne National Laboratory), undated. Autonomie Model, Energy Systems Division. Available at https://www.autonomie.net/, accessed July 9, 2020. 
Lee, D-Y, A. Elgowainy, and Q. Dai, 2017. Life Cycle Greenhouse Gas Emissions of By-product Hydrogen from Chlor-Alkali Plants, ANL/ESD-17/27, Argonne National Laboratory, Argonne, IL. Available at https://greet.es.anl.gov/publication-chlor_alkali_h2, accessed July 9, 2020.

DOE (U.S. Department of Energy), 2020.H2@ Scale, Office of Energy Efficiency and Renewable Energy, Available at https://www.energy.gov/eere/fuelcells/h2scale, accessed July 13. 2020.

ORNL (Oak Ridge National Laboratory), undated, MA3T Model. Available at https://www.ornl.gov/content/ma3t-model, accessed July 9, 2020. 


\section{PETROLEUM REFINING}

Petroleum refineries are the largest consumer of hydrogen in the United States today, consuming about 10 MMT of hydrogen annually, including hydrogen produced at the refinery as a by-product of the refining process (Brown 2016). As shown in Figures 2.1 and 2.2, the three major sources of hydrogen supplied to refineries are hydrogen purchased from merchant plants, captive by-product hydrogen produced internally from catalytic reforming of naphtha, and captive hydrogen produced internally via SMR of NG. Major hydrogen-consuming processes in U.S. refineries are hydrocracking, gas oil (FCC feed) hydrotreating, ultra-low-S diesel hydrotreating, and naphtha hydrotreating. Hydrocrackers mainly produce diesel from heavy crude. Hydrotreaters remove sulfur from various feed, intermediate, and product streams (e.g., gas oil hydrotreaters remove sulfur from heavy crude cuts). Therefore, hydrogen demands by petroleum refineries depend not only on crude volume and product slate (e.g., ratio of gasoline-to-diesel production), but also on the heaviness (measured by API gravity) and sulfur content of crude input.

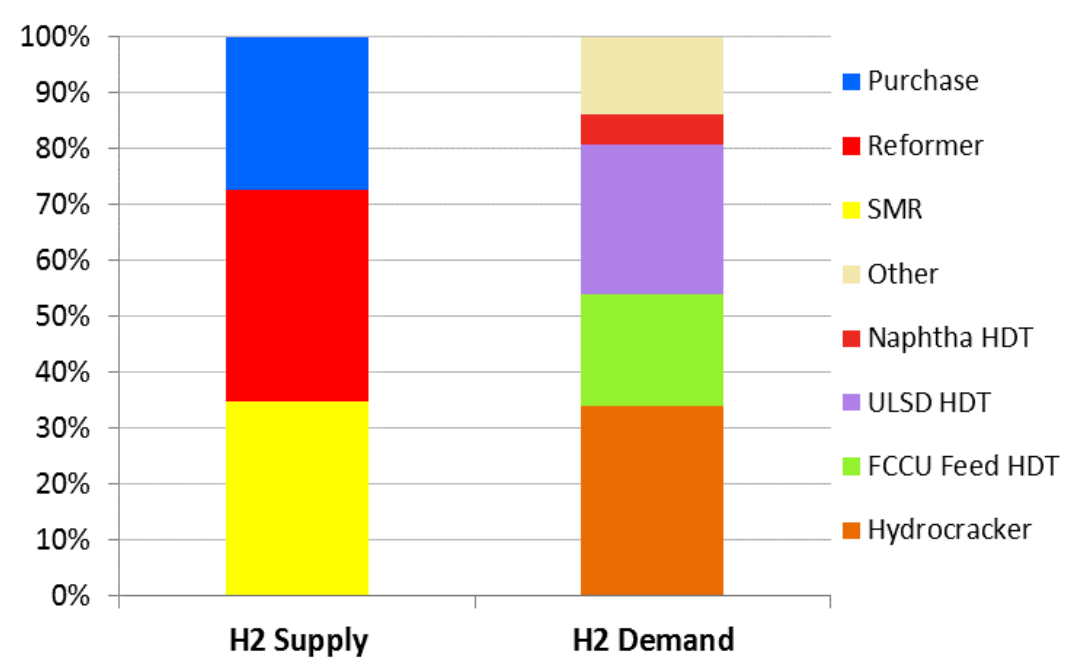

FIGURE 2.1 Hydrogen Supply and Demand for Major Processing Units in 43 Refineries (Elgowainy et al. 2014)

\subsection{National Hydrogen Demand for Petroleum Refining}

Figure 2.3 shows the steps and sources used to assess demand for hydrogen in petroleum refineries. Current and projected data on crude inputs and product slates, shown in Figure 2.4, were obtained from EIA's Annual Energy Outlook 2017 (EIA 2017a). According to that projection, gasoline blendstock consumption will decline by 1.8 million bbl/day from 2015 to 2050, while crude inputs and diesel and jet fuel consumption will rise by 1.5, 0.2, and 1.0 million $\mathrm{bbl} / \mathrm{day}$, respectively. It should be noted that the export of petroleum products is also projected to increase by 2.1 million bbl/day over this period. As presented in Sections 8 and 9), this study 
examines potential demand for hydrogen by FCEVs, which could displace petroleum and thereby reduce future crude oil inputs and alter product slates, as well as affect refinery product exports. However, the effect of such changes on petroleum refiners (e.g., the extent to which exports could make up for lower domestic demand) was beyond the scope of this analysis.

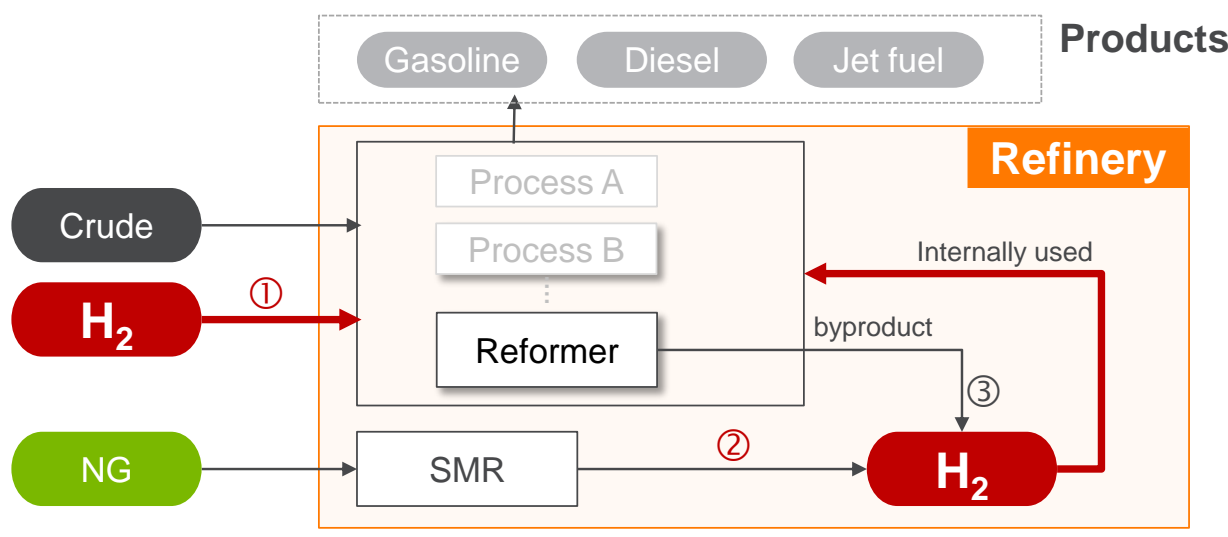

FIGURE 2.2 Hydrogen Demand in Refineries: (1) Imported (Merchant) Hydrogen, (2) Internal Hydrogen Produced from NG, and (3) By-product Hydrogen from Naphtha Reformer

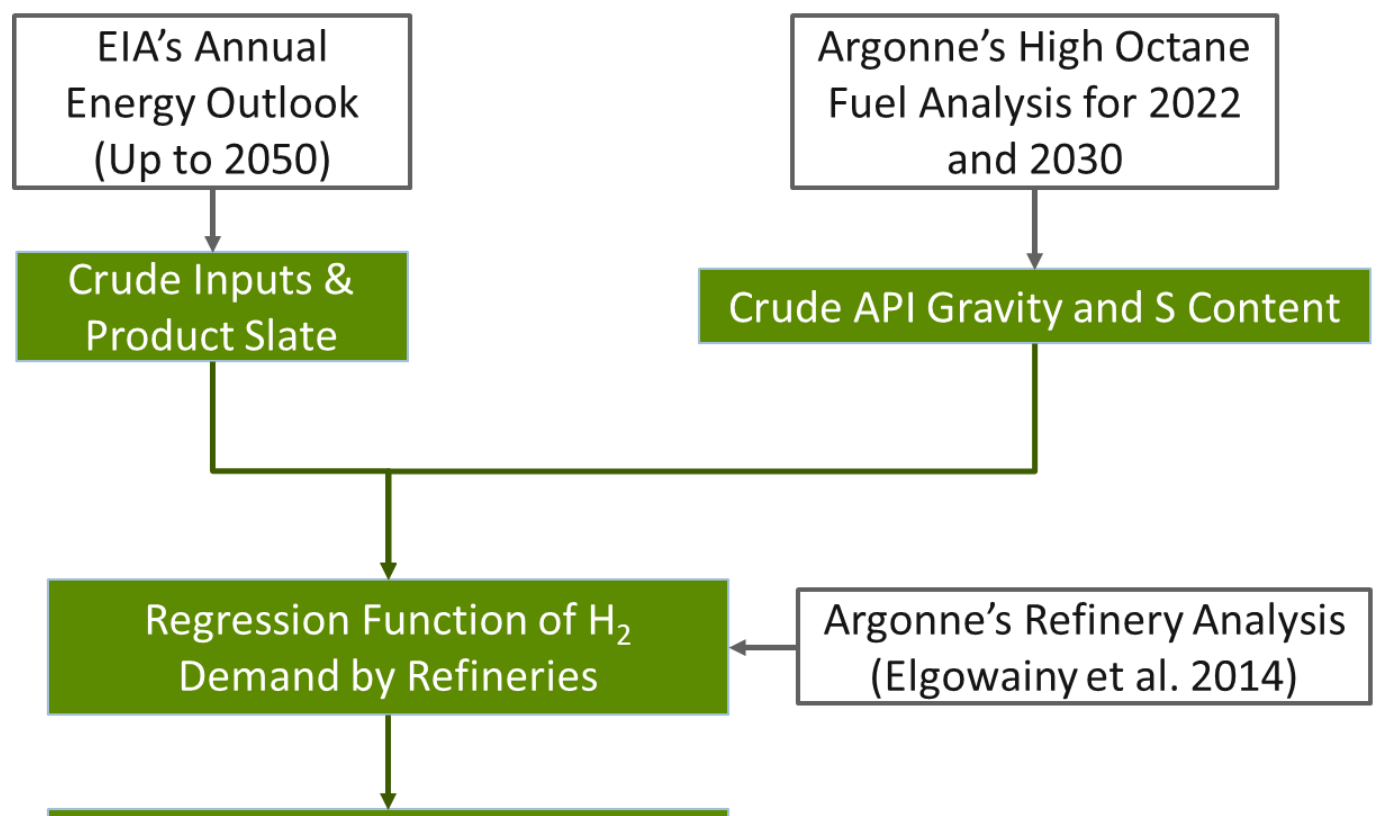

\section{$\mathrm{H}_{2}$ Demand (US, PADD Regions)}

FIGURE 2.3 Steps in Assessing Hydrogen Demand by Petroleum Refineries ${ }^{4}$

\footnotetext{
4 PADD $=$ Petroleum Administration for Defense District.
} 


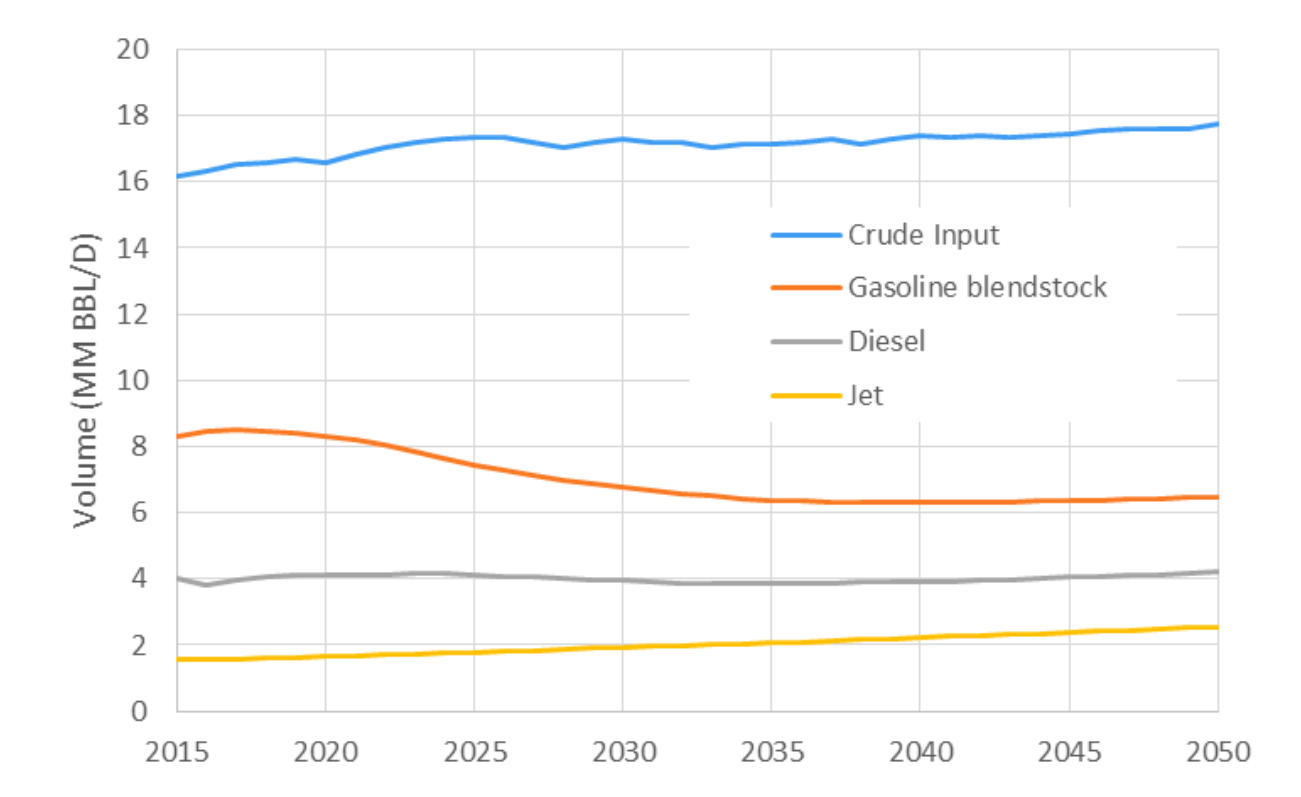

FIGURE 2.4 Projections of Crude Input and Gasoline, Diesel, and Jet Fuel Production (EIA 2017a)

Assumptions for crude quality (API gravity and S content) were based on Argonne's high-octane fuel (HOF) analysis (Han et al. 2015). That analysis included linear programming modeling of refineries to estimate the impact of HOF production in 2022 and 2030. As shown in Figure 2.5, the HOF study estimated an increase in API gravity from 31.5 in 2015 to 31.7 in 2022 , and in $\mathrm{S}$ content from $1.39 \%$ in 2015 to $1.61 \%$ in 2022 , whereas crude quality was assumed to remain constant after 2022.

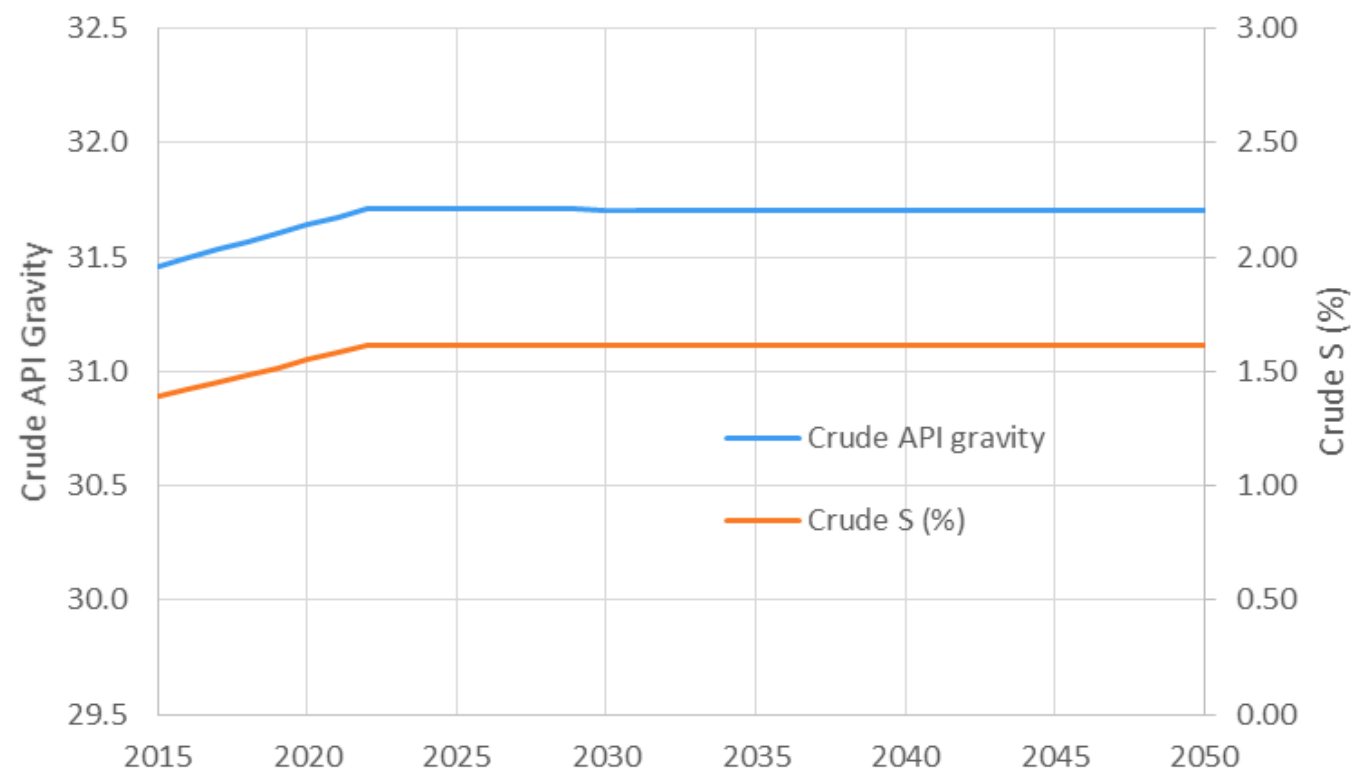

FIGURE 2.5 Projections of Crude Oil's API Gravity and S Content 
To assess future hydrogen demand by U.S. refineries, the hydrogen intensity of crude refining (in $\mathrm{mmBtu} / \mathrm{mmBtu}$ crude) was estimated and then multiplied by the projected volume of crude input. To that end, this study developed a regression function for the hydrogen intensity of crude refining using refinery operation data from 2009 and 2015 for the five Petroleum Administration for Defense District (PADD) regions and the United States (EIA 2017b).

Refinery operation data included the amount of total crude inputs, product outputs, purchased (or merchant) hydrogen, NG inputs for on-site hydrogen production, and crude API gravity and S content. Using four parameters - crude API gravity, S content, gasoline-to-distillate (G/D) ratio, and ratio of liquefied petroleum gas to total product (LPG/Total) - the following regression formula was developed with $\mathrm{R}^{2}$ of 0.89 :

Hydrogen intensity $(\mathrm{mmBtu} / \mathrm{mmBtu}$ Crude $)=0.059-0.00175 \times($ Crude API Gravity $)$ $+0.02218 \times(\mathrm{S} \%)-0.00139 \times(\mathrm{G} / \mathrm{D}$ Ratio $)-0.59416 \times(\mathrm{LPG} / \mathrm{Total})$

The data samples cover crude API gravity ranging from 28.5 to 34.3 , S content ranging from $0.65 \%$ to $1.6 \%$, and G/D ratio ranging from 0.5 to 5.8 .

Figure 2.6 compares the hydrogen intensity estimated by the regression model with actual hydrogen intensity samples. The solid line is where the estimated hydrogen intensities match the actual hydrogen intensity samples. Thus, the closer to the solid line the dots are located, the better the estimates by the regression function. The two dotted lines indicate the $95 \%$ prediction intervals. This study used the above regression function (solid line) to estimate the "MID"-case hydrogen intensity, while the upper and lower bounds in the 95\% prediction intervals were used for the "HIGH"- and "LOW"-case hydrogen intensity, respectively, as shown in Figure 2.7. The sharp hydrogen intensity increase from 2015 to 2022 implies a strong dependence on crude quality parameters, such as S content and API gravity. Figure 2.7 also implies that the impact of the regression function bounds (LOW vs. HIGH) is not significant.

Multiplying the crude input (Figure 2.4) by the hydrogen intensity (Figure 2.7) provides an estimate of the growth in annual hydrogen demand by U.S. refineries through 2050 (Figure 2.8). Because crude inputs in the baseline case are projected to increase steadily, the projected hydrogen consumption volume is determined mainly by the hydrogen intensity. 


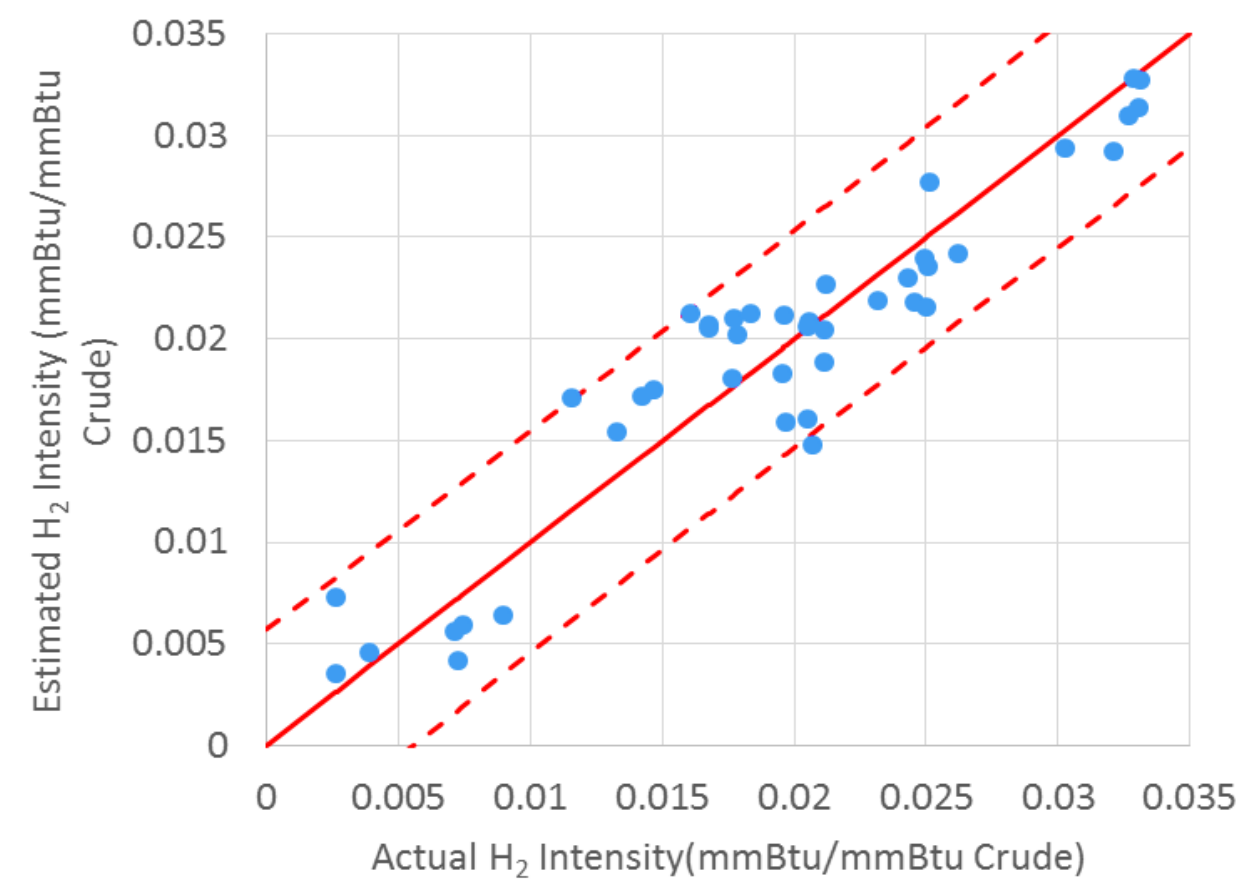

FIGURE 2.6 Comparison of Hydrogen Intensity Estimated by the Regression Function with the Actual Hydrogen Intensity Samples

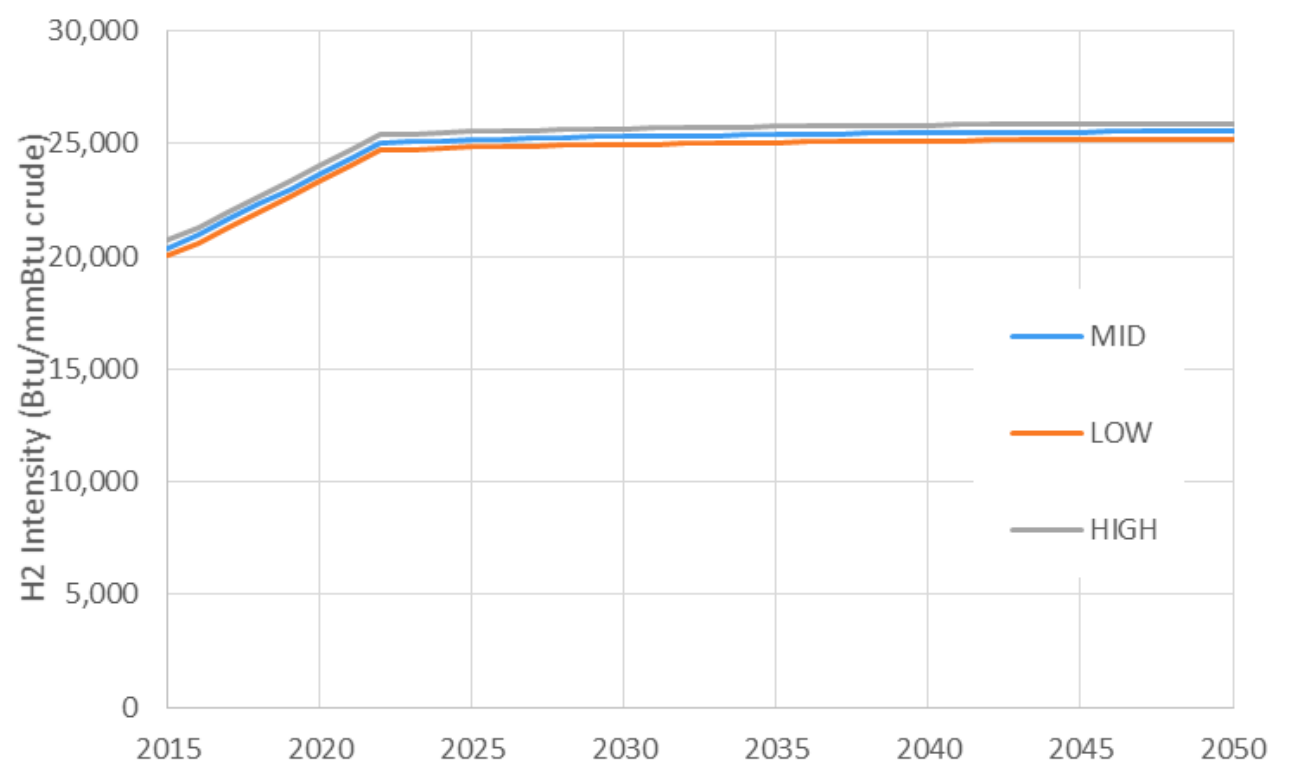

FIGURE 2.7 Projection of Hydrogen Intensity Estimated by the Regression Function Using the Crude API Gravity and S Content and G/D Ratio for the Baseline U.S. Refineries 


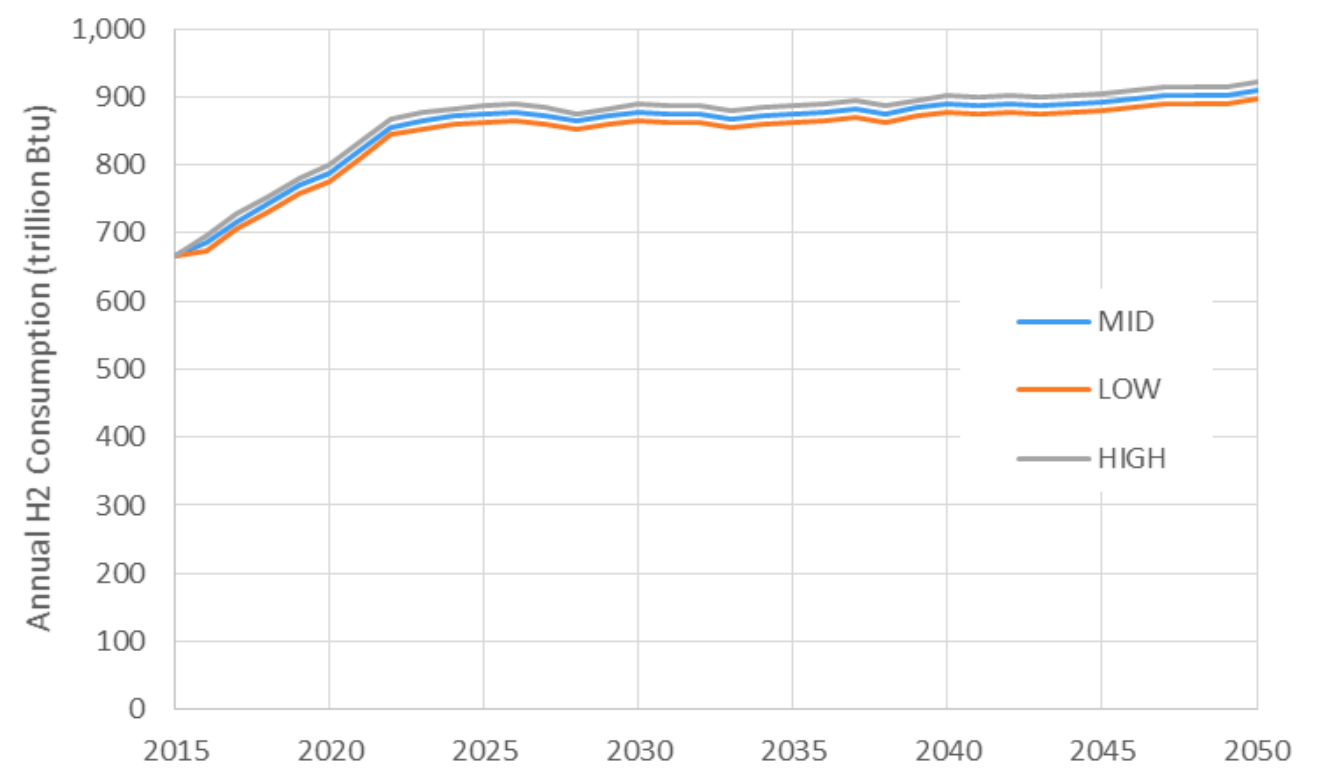

FIGURE 2.8 Projection of Hydrogen Demand by U.S. Refineries through 2050

\subsection{Regional Hydrogen Demand for Petroleum Refining}

Because refineries currently dominate U.S. hydrogen demand, the geographic distribution of refineries has important implications for understanding proximity and logistics issues within the H2@Scale assessment. In this analysis, hydrogen demand for crude oil refining was projected for each PADD (Section 2.2.1), along with a broad assessment of demand at the refinery or facility level (Section 2.2.2).

\subsubsection{PADD-level Analysis}

The EIA (2018a) provides PADD-level refinery data, from which hydrogen input can be obtained. Data on NG used as a feedstock for hydrogen production also are available at the PADD level (EIA 2018b), and can be used to estimate the amount of captive hydrogen production within refineries. As shown below, 1 mole of $\mathrm{NG}$ methane $\left(\mathrm{CH}_{4}\right)$ and two moles of steam generate 4 moles of hydrogen, and this stoichiometric methane-to-hydrogen ratio is used to estimate the amount of hydrogen produced from the EIA-reported NG feedstock inputs.

$$
\begin{aligned}
& \text { SMR: } \mathrm{CH}_{4}+\mathrm{H}_{2} \mathrm{O} \rightarrow \mathrm{CO}+3 \mathrm{H}_{2} \\
& \text { Water-gas shift reaction: } \mathrm{CO}+\mathrm{H}_{2} \mathrm{O} \rightarrow \mathrm{CO}_{2}+\mathrm{H}_{2}
\end{aligned}
$$

Refinery capacity is also a key factor determining hydrogen demand. Figure 2.9 shows atmospheric crude distillation capacity at U.S. refineries from 2009 to 2016 by PADD (EIA 2018c). This capacity has increased by just $4 \%$ over this timeframe. The EIA projects this trend to continue into the future, with distillation capacity increasing by only $9 \%$ from 2016 to 2050 (EIA 2017b). 


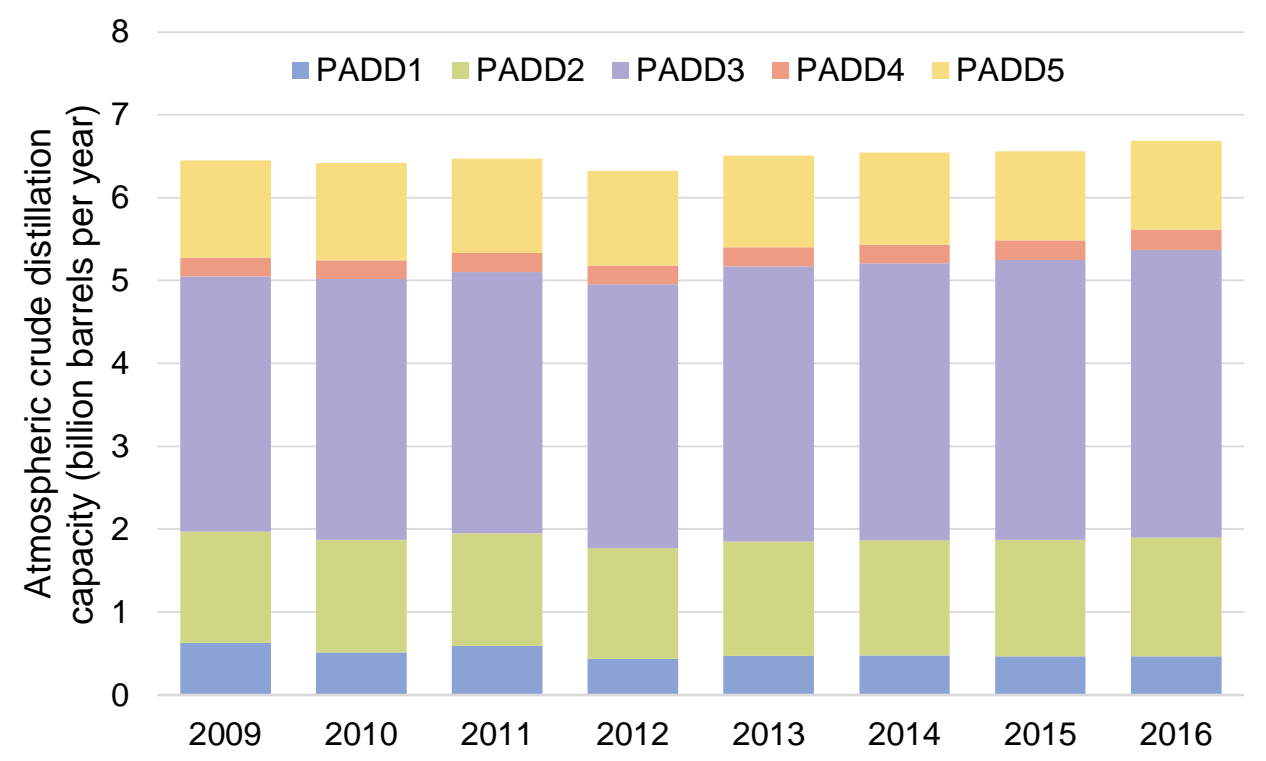

FIGURE 2.9 U.S. Refinery Capacity from 2009 to 2016 (EIA 2018c)

Although there has been no significant change in the total capacity of U.S. refineries, refinery demand for hydrogen has increased significantly (Figure 2.10). As mentioned earlier, net hydrogen demand was estimated on the basis of hydrogen and NG input data (EIA 2018b,c). Recent increases in hydrogen demand have been attributable primarily to increases in the dieselto-gasoline ratio, and the processing of heavier (lower-API-gravity) and sourer (higher-S) crudes, all of which require more hydrogen inputs, as previously explained. These trends have not been uniform across all PADDs, however. As shown in Figure 2.11, the hydrogen consumption rate (standard cubic feet of hydrogen per bbl of crude oil) varies widely among PADDs, a reflection of large variations in crude quality, refinery complexity, and product slates. Figure 2.11 also shows an overall upward trend in hydrogen demand to refine crude oil over the years, especially in PADDs 2, 3, and 5, where more than $90 \%$ of crude refining in the United States occurs. 


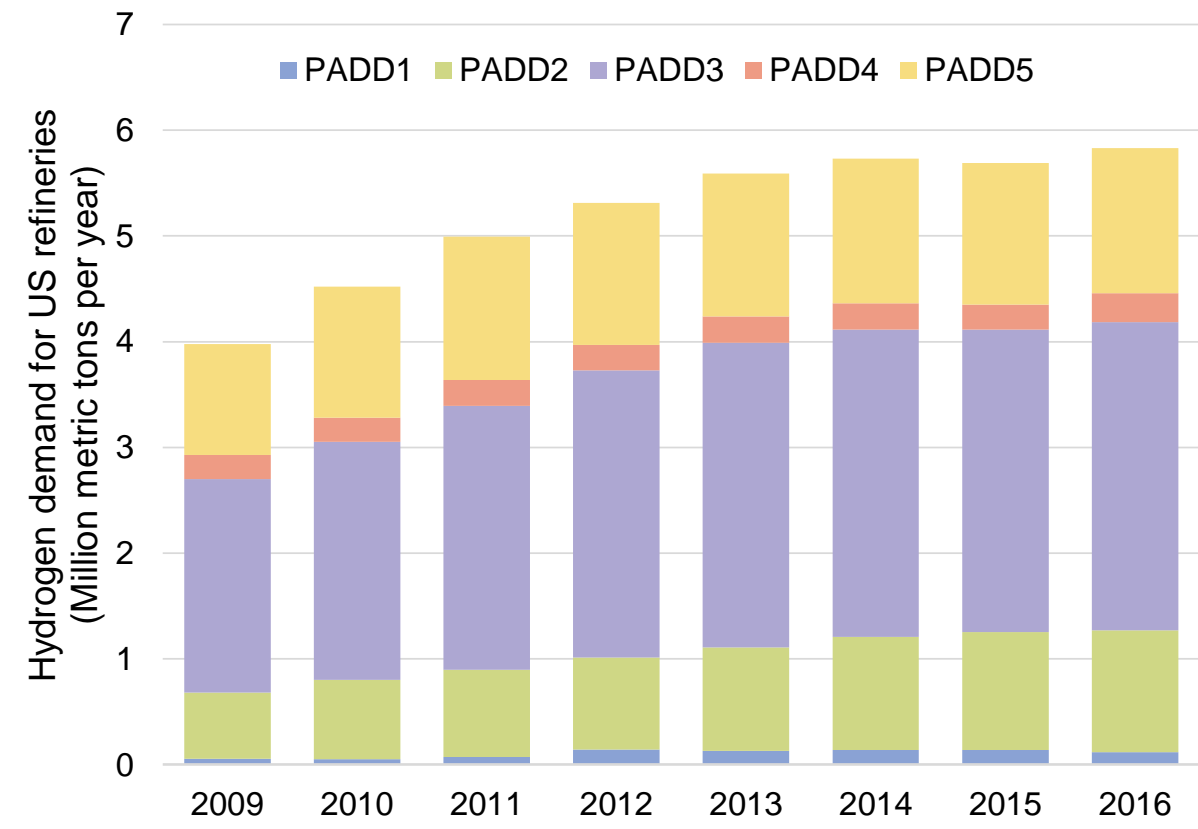

FIGURE 2.10 Hydrogen Demand for U.S. Refineries by PADD

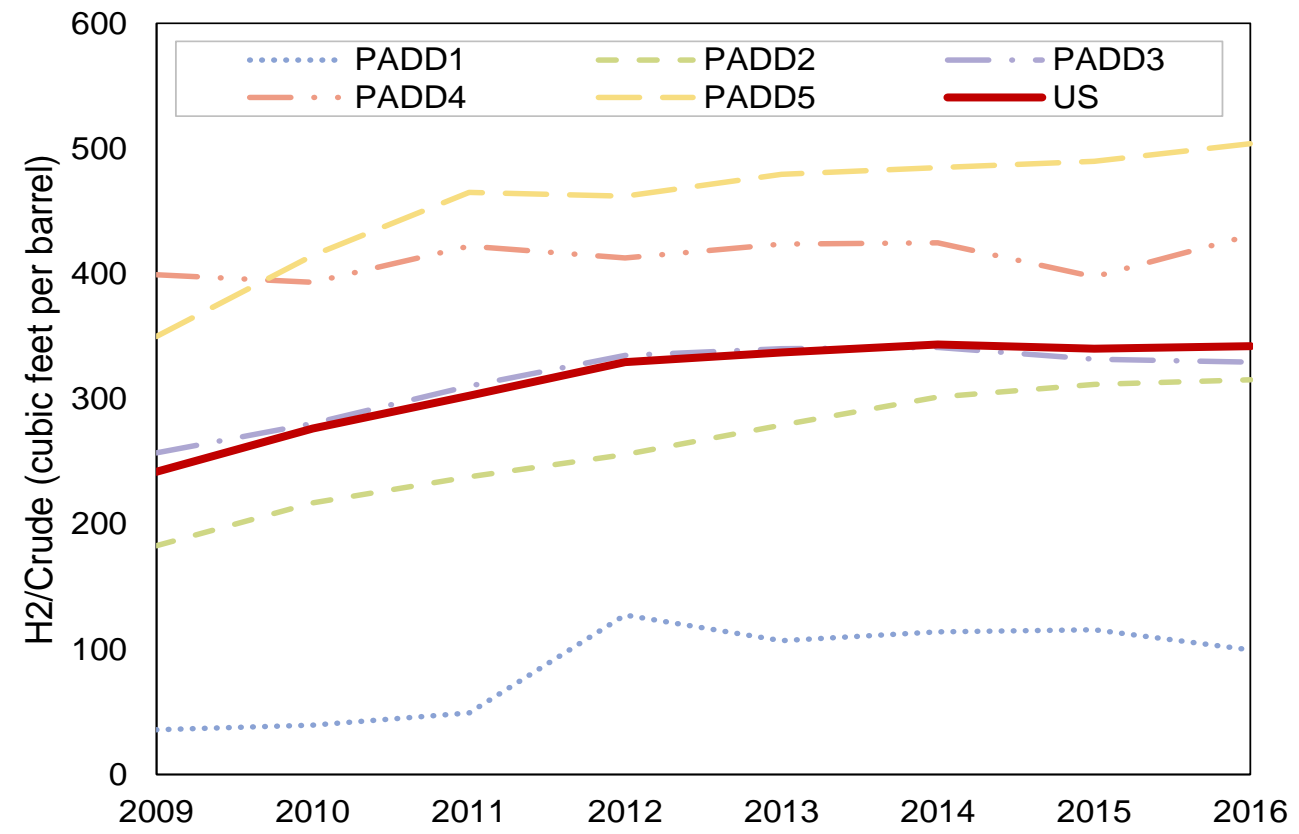

FIGURE 2.11 Hydrogen Demand Intensity in the United States and by PADD 


\subsubsection{Facility-level Analysis}

To estimate hydrogen demand growth for each refinery, the average PADD-level increase in hydrogen demand was applied to each refinery. Owing to the limited data available at the facility level, it was assumed that the hydrogen consumption rate of each PADD would apply to all refineries in the region. Hydrogen demand at each facility then was estimated as the product of the crude capacity of each refinery and the PADD-level hydrogen/crude ratio. Figure 2.12 displays the resulting estimate of hydrogen demand at the facility level in 2017 . Note that the size of each shaded dot corresponds to the relative size of each refinery's hydrogen demand.

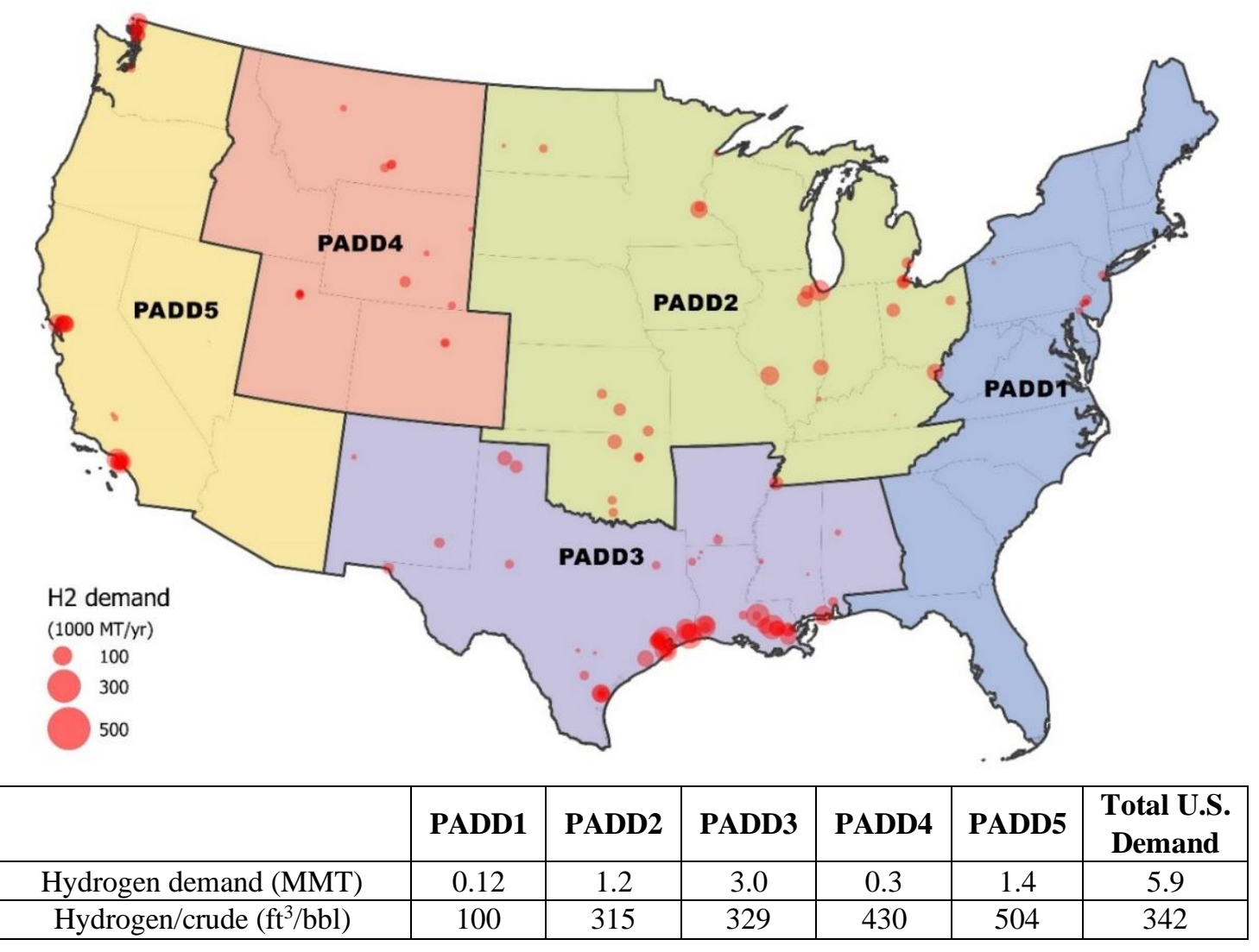

FIGURE 2.12 Hydrogen Demand by U.S. Refineries in 2017

\subsubsection{Regional Demand}

Figure 2.12 also shows hydrogen demand by PADD, estimated at 5.9 MMT overall (other than reformer by-product hydrogen) in 2017. More than half of that demand was from PADD3.

To assess future hydrogen demand for each PADD, the average national demand growth rate projected in Figure 2.8 was applied to the hydrogen consumption rate projected for the respective PADD (Figure 2.11). Han et al. (2015) estimated that the hydrogen consumption rate would increase in the near future because of changes in crude API gravity and S content. In 
addition to changes in crude input to refineries (shown in Figure 2.4), increases in the diesel/gasoline ratio would also contribute to growth in hydrogen demand by refineries. Figure 2.13 shows the estimated growth in hydrogen demand intensity per unit of crude oil processed by PADD through 2050, and Figure 2.14 shows the estimated growth in total hydrogen demand in refineries by PADD through 2050. As shown in Figure 2.14, the total captive and merchant hydrogen demand (other than reformer by-product hydrogen) by U.S. refineries is projected to grow by $27 \%$ in 2030 (to 7.5 MMT) as compared to 2017. To be conservative and owing to a lack of estimates of crude quality (e.g., API gravity and sulfur content) beyond 2030, hydrogen demand was assumed to grow modestly, proportionally with crude input, between 2030 and 2050. While hydrogen demand for crude refining showed some volatility between 2010 and 2017, hydrogen demand between 2018 and 2050 was projected as a smooth trend, owing to inherent uncertainties in the magnitude and timing of price shocks and other external events that affect world economies and oil markets.

Because the EIA projects an increase of only $9 \%$ in distillation capacity between 2015 and 2050, all of which occurs by 2030, PADD-level demand for hydrogen in U.S. refining is flat between 2030 and 2050 (Figure 2.14).

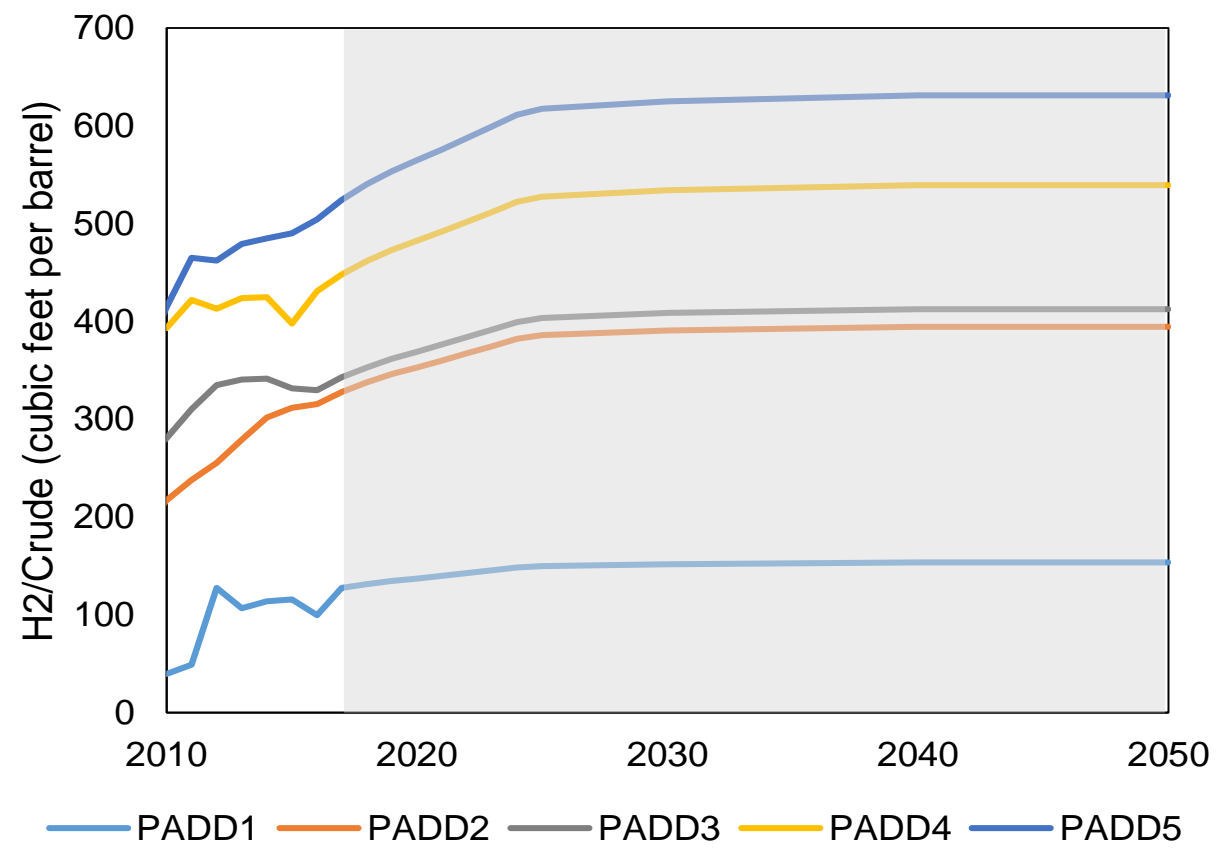

FIGURE 2.13 Projected Hydrogen Demand Intensity (Hydrogen/ Crude) by PADD through 2050 


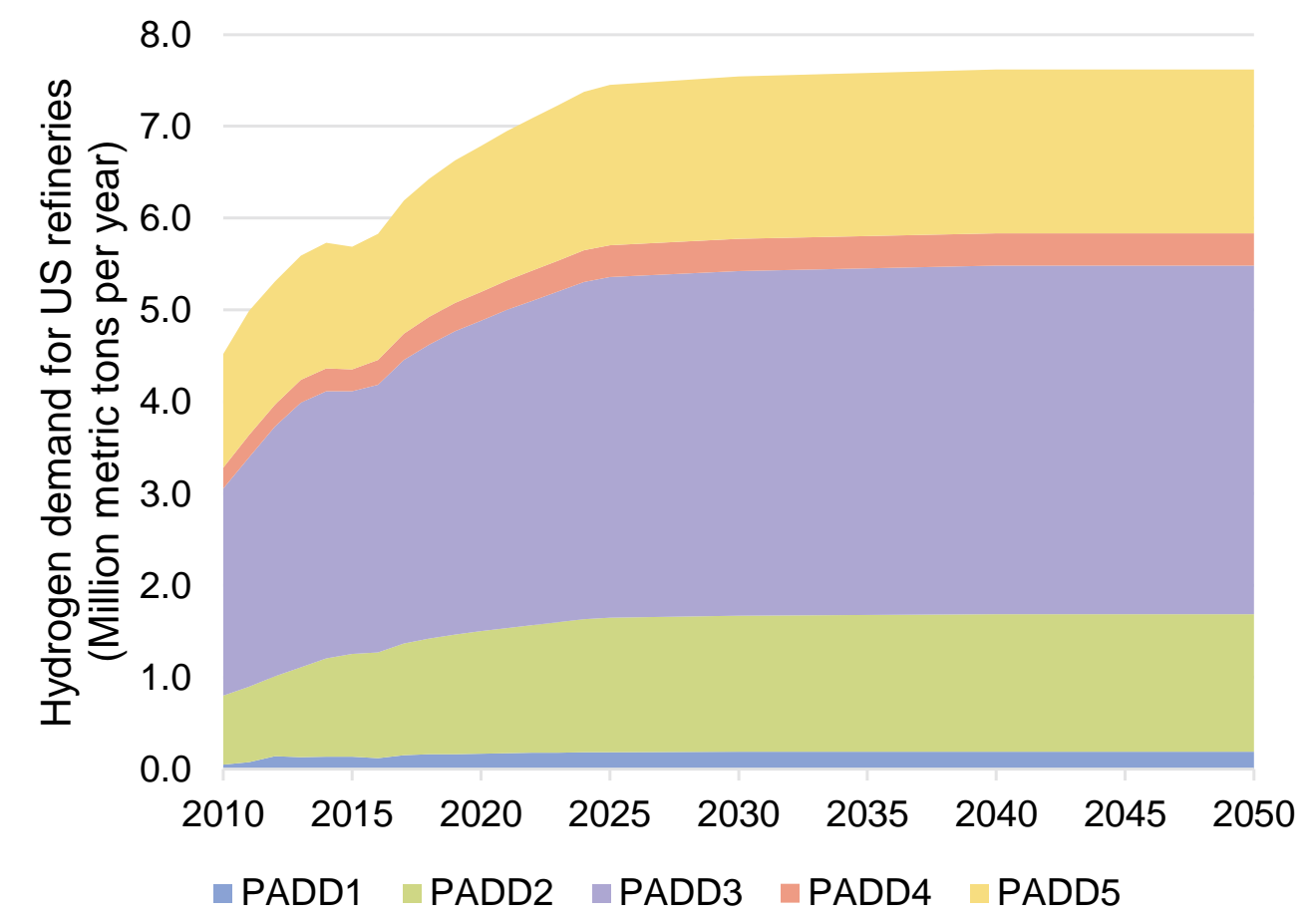

FIGURE 2.14 Projected Total Hydrogen Demand for U.S. Refineries by PADD through 2050

For hydrogen production via low-temperature electrolysis (LTE) and high-temperature electrolysis (HTE) of water (using solar, wind, and nuclear sources) to grow and capture new markets, its production cost must be competitive with the cost of hydrogen production via NG SMR. However, in the event of higher feedstock prices (e.g., price of NG), it is expected that hydrogen demand for petroleum refining will likely be inelastic for these reasons: because hydrogen is an essential feedstock to the refining process, its contribution to the total refining cost is relatively small, and because the demand for petroleum products (e.g. gasoline) is largely inelastic to price. ${ }^{5}$

\subsection{References}

Brown, D., 2016. "US and World Hydrogen Production - 2014," Pacific Northwest National Laboratory.

EIA (U.S. Energy Information Administration), 2017a. Annual Energy Outlook 2017, DOE/EIA0383(2017), Washington, D.C. Available at https://www.eia.gov/outlooks/aeo/, accessed July 10, 2020.

EIA, 2017b. "Petroleum \& Other Liquids." Available at https://www.eia.gov/petroleum/, accessed July 10, 2020.

${ }^{5}$ https://www.eia.gov/todayinenergy/detail.php?id=19191, accessed July 10, 2020. 
EIA, 2018a. "Petroleum \& Other Liquids: Refinery \& Blender Net Input." Available at https://www.eia.gov/dnav/pet/PET_PNP_INPT_A_EPOOOH_YIR_MBBL_A.htm, accessed July 10, 2020.

EIA, 2018b. "Petroleum \& Other Liquids: Natural Gas Used as Feedstock for Hydrogen Production.” Available at https://www.eia.gov/dnav/pet/pet_pnp_feedng_k_a.htm, accessed July 10, 2020.

EIA, 2018c. "Petroleum \& Other Liquids: Refinery Capacity Report." Available at https://www.eia.gov/petroleum/refinerycapacity/, accessed July 10, 2020.

Elgowainy, A., J. Han, H. Cai, M. Wang, G.S. Forman, and V.B. DiVita, 2014. "Energy Efficiency and Greenhouse Gas Emission Intensity of Petroleum Products at U.S. Refineries," Environmental Science \& Technology, Vol. 48(13):7612-7624. Available at https://doi.org/10.1021/es5010347, accessed July 10, 2020.

Han, J., A. Elgowainy, M.Q. Wang, and V.B. DiVita, 2015. Well-To-Wheels Analysis of High Octane Fuels with Various Market Shares and Ethanol Blending Levels, ANL/ESD-15/10, Argonne National Laboratory, Argonne, IL. 


\section{BIOFUEL PRODUCTION}

Figure 3.1 illustrates the steps in the assessment of hydrogen demand for biofuel production. The assessment starts with estimates of biofuel consumption for marine and aviation applications in 2050. Because each biofuel production technology requires a certain amount of hydrogen for conversion, hydroprocessing, and/or hydrotreating, the total hydrogen demand for biofuel production is then calculated by multiplying projected biofuel production by the hydrogen required for input. Additional hydrogen demand is also estimated to account for the growth in $\mathrm{NH}_{3}$ production needed to enable higher biomass production to support the aforementioned growth in biofuel production; $\mathrm{NH}_{3}$ is used as a finished fertilizer and as an intermediate in other $\mathrm{N}$ fertilizers, both of which are utilized in biomass production. Finally, we note that increased biofuel use may displace gasoline, diesel, and jet fuel domestically, which could affect hydrogen demand by U.S. refineries. However, the impact of biofuel production scenarios on refinery operations is outside the scope of this analysis.

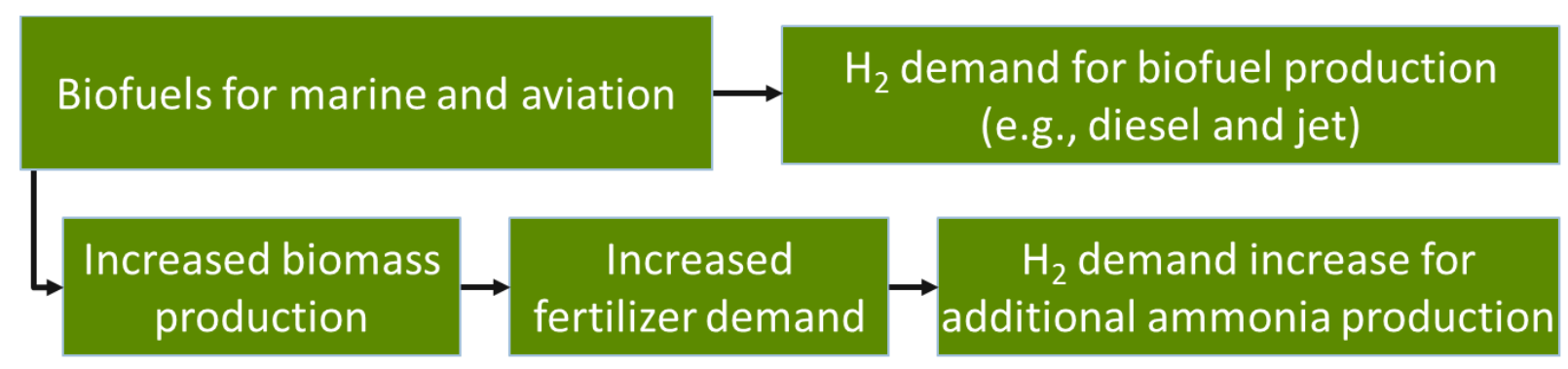

FIGURE 3.1 Conceptual Approach for Assessing Hydrogen Demand for Biofuel Production

This study assumed that non-road applications like those in the marine and aviation sectors will continue to use liquid hydrocarbon fuels because of their high volumetric and gravimetric energy density. Thus, the more likely pathways for their decarbonization will be through the use of low-carbon drop-in fuels, such as biofuels. The EIA's Annual Energy Outlook (EIA 2017) projects 2.52 million barrels per day or 38.6 billion gallons per year of jet fuel production in the United States in 2050. For this analysis, we assumed the American Society for Testing and Materials (ASTM) allowance of up to 50\% biofuel blending for aviation applications (ASTM 2020) as a maximum blend percentage (i.e., 19.3 billion gallons in 2050). We also assumed that 0.25 quad or 1.8 billion gallons of "green liquids" will come from the hydrotreatment of fats, oils, and greases (FOGs) (EIA 2017). This leaves 17.5 billion gallons of biofuel consumption in 2050, which we assumed would be produced via catalytic fast pyrolysis of woody biomass.

We relied on the work of Dutta et al. (2020) to estimate the hydrogen requirement for converting woody biomass to liquid hydrocarbon. According to that work, an estimated 490 grams of hydrogen are needed to produce a gallon of bio-jet fuel via catalytic fast pyrolysis of woody biomass. Thus, to produce 17.5 billion gallons of bio-jet, 8.6 MMT of hydrogen will be needed for that conversion process. 
Furthermore, we estimate that between $0.02-0.03 \mathrm{~kg}$ of hydrogen is needed to hydrotreat FOGs and produce a $\mathrm{kg}$ of biofuel. At $\sim 0.025 \mathrm{~kg}$ of $\mathrm{H}_{2}$ per $\mathrm{kg}$ of biofuel, approximately 76 grams of hydrogen are needed to produce a gallon of biofuel from FOGs. Thus, we estimated the potential hydrogen demand for producing 1.8 billion gallons of biofuel from FOGs at 0.14 MMT annually. Combining the potential hydrogen demand for catalytic fast pyrolysis of woody biomass and hydrotreatment of FOGs to produce biofuels for aviation use, we estimate a total potential future hydrogen demand for biofuel production at 8.74 MMT annually.

As mentioned earlier, additional biofuel production increases the requirement for biomass farming and harvest. Growth in biomass production necessitates growth in $\mathrm{NH}_{3}$ production, which will create additional hydrogen demand beyond that estimated in Section 4 . Note that $\mathrm{N}$ fertilizer intensity depends on feedstock type and $\mathrm{N}$ fertilizer application efficiency. For energy crops (such as miscanthus, switchgrass, willow, and poplar), this study uses the $\mathrm{N}$ fertilizer intensity from Greenhouse gas, Regulated Emissions and Energy use in Transportation (GREET) (see Table 3.1), which is derived from the Billion Ton Study analysis (DOE 2016). In Dutta et al. (2020), cellulosic biomass was assumed to be primarily woody. Assuming a yield of 72 gallons of biofuel per dry ton of woody biomass, approximately 270 million dry tons/year of woody biomass are required to produce 19.3 billion gallons of biofuels. Using the nitrogen application rate for poplar, we estimate hydrogen demand of approximately 0.1 MMT for fertilizer production needed to grow 270 million tons of woody biomass.

TABLE 3.1 N Fertilizer Application Rates for Energy Crops ( $\mathrm{N} \mathrm{kg/dry} \mathrm{ton} \mathrm{delivered} \mathrm{to} \mathrm{plant}$ gates)

\begin{tabular}{cc}
\hline Energy Crop & $\begin{array}{c}\text { N Fertilizer } \\
\text { Application rate }\end{array}$ \\
\hline Corn stover & 8.77 \\
Miscanthus & 4.08 \\
Switchgrass & 4.29 \\
Forest and urban residue & 0.00 \\
Willow & 1.46 \\
Poplar & 1.97 \\
\hline
\end{tabular}

We assumed that any method of hydrogen production to supply bio-refineries must be competitive with hydrogen from SMR of NG, the incumbent method of hydrogen production for this market. We also assumed that hydrogen demand for biofuel production will be inelastic relative to hydrogen market price. 


\subsection{References}

ASTM (American Society for Testing and Materials), 2020. Standard Specification for Aviation Turbine Fuel Containing Synthesized Hydrocarbons, ASTM D7566-20.

DOE (U.S. Department of Energy), 2016. 2016 Billion-Ton Report: Advancing Domestic Resources for a Thriving Bioeconomy, Volume 1: Economic Availability of Feedstocks, ORNL/TM-2016/160, Oak Ridge National Laboratory, Oak Ridge, TN. Available at https://energy.gov/sites/prod/files/2016/12/f34/2016_billion_ton_report_12.2.16_0.pdf, accessed July 11, 2020.

Dutta, A., K. Iisa, M. Talmadge, C. Mukarakate, M. Griffin, E. Tan, N. Wilson, M. Yung, M. Nimlos, J. Schaidle, H. Wang, M. Thorson, D. Hartley, J. Klinger, and H. Cai, 2020. Ex Situ Catalytic Fast Pyrolysis of Lignocellulosic Biomass to Hydrocarbon Fuels: 2019 State of Technology and Future Research, NREL/TP-5100-76269. Available at https://www.nrel.gov/docs/fy20osti/76269.pdf, accessed July 11, 2020.

EIA, 2017. Annual Energy Outlook 2017, Table: Petroleum and Other Liquids Supply and Disposition, Low Oil and Gas Resource Case. 


\section{AMMONIA (NH3) PRODUCTION}

$\mathrm{N}$ fertilizer is an integral part of food- and energy-crop production. While various types of $\mathrm{N}$ fertilizers such as $\mathrm{NH}_{3}$, urea, diammonium phosphate, monoammonium phosphate, and nitric acid are used, $\mathrm{NH}_{3}$ is the key building block for all other $\mathrm{N}$ fertilizers. In the $\mathrm{NH}_{3}$ synthesis process, known as the Haber-Bosch process, 3 moles of hydrogen are combined with 1 mole of $\mathrm{N}_{2}$ to produce 2 moles of $\mathrm{NH}_{3}$. Thus, $0.178 \mathrm{~kg}$ of hydrogen is needed to produce $1 \mathrm{~kg} \mathrm{of} \mathrm{NH}_{3}$, or $0.216 \mathrm{~kg}$ of hydrogen is needed to produce $1 \mathrm{~kg}$ of $\mathrm{N}$ in the $\mathrm{N}$ fertilizer.

\subsection{National Hydrogen Demand for Ammonia Production}

In order to estimate the quantity of hydrogen needed to produce $\mathrm{NH}_{3}$ for agricultural use, agricultural production and the quantity of $\mathrm{NH}_{3}$ needed to support that production must first be determined (see Figure 4.1). According to the U.S. Geological Survey (USGS), $88 \%$ of $\mathrm{NH}_{3}$ consumption in the United States is for fertilizer use; the remaining $12 \%$ is for the production of explosives, plastics, synthetic fibers, resins, and numerous other chemical compounds (USGS 2017). The U.S. Department of Agriculture (USDA) has projected agricultural commodity production to 2029 (USDA 2020). The present study extended those projections from 2030 through 2050 by assuming that the production of each crop would increase or decrease at the average rate projected from 2020 to 2029; the overall results are shown in Figure 4.2. Note that USDA's projections cover only agricultural commodities; hence, many agricultural products are not included. Corn and soybeans, the dominant agricultural commodities produced in the United States, are included, as are fruits and nuts (including citrus, non-citrus, and tree nuts), other grains, and vegetables (e.g., fresh market and processing vegetables, peas, and beans). We also note that while crop production fluctuated between 2018 and 2020 because of variations in planted acreage and yield, annual production estimates from 2020 onward show a smooth trend, reflecting inherent uncertainties in year-to-year conditions. 


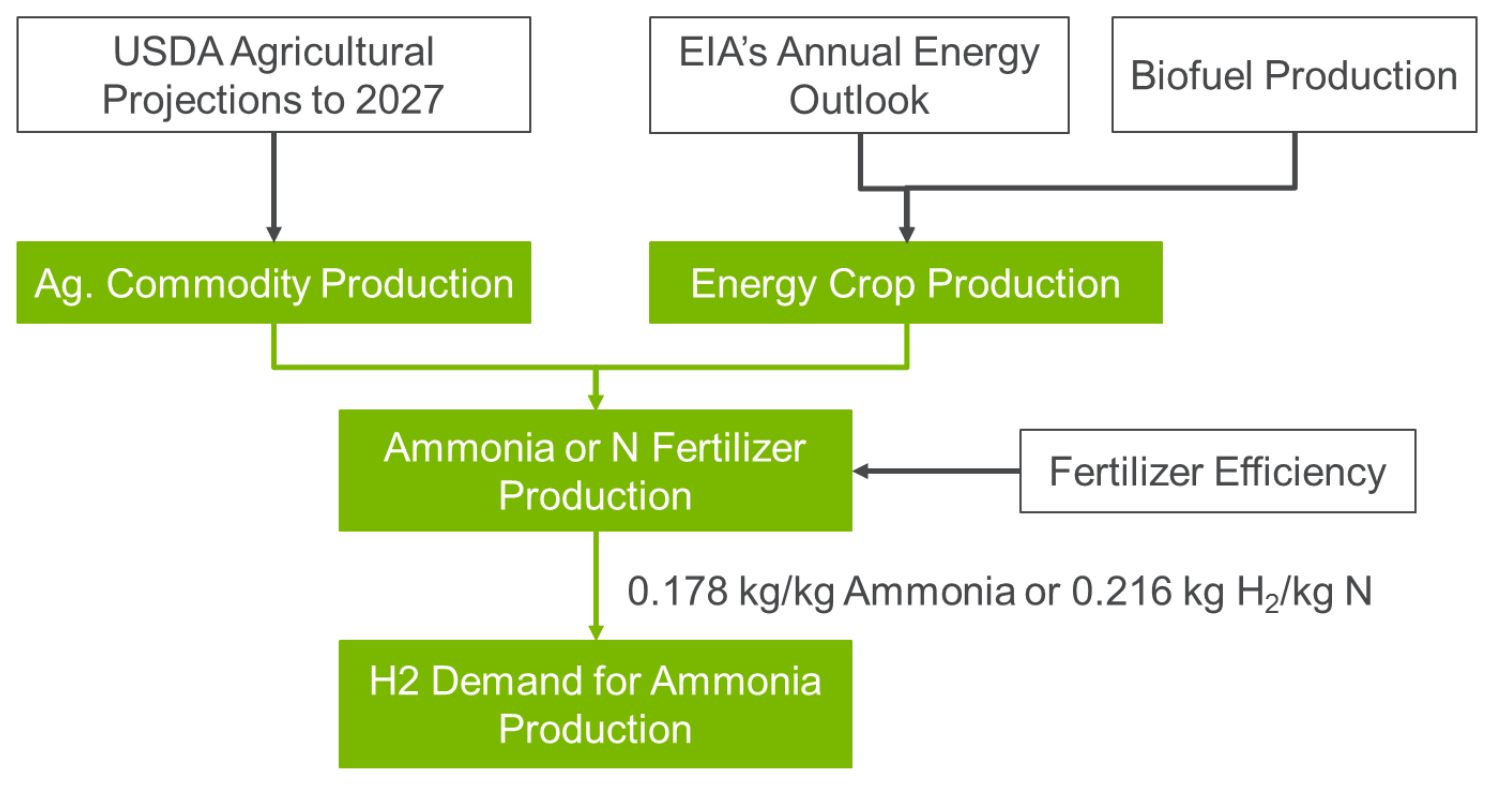

FIGURE 4.1 Steps in Hydrogen Demand Assessment for $\mathrm{NH}_{3}$ Production

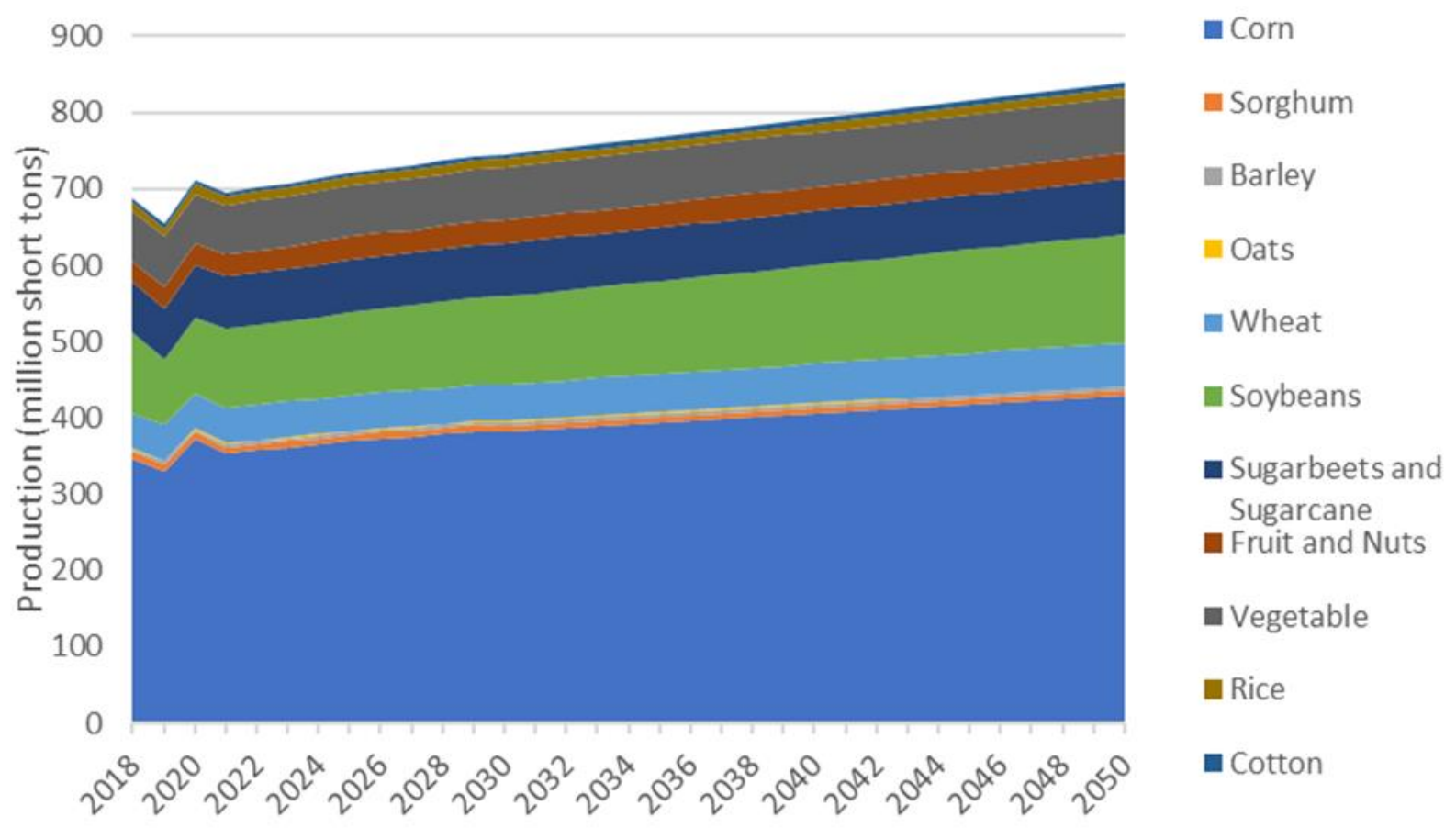

FIGURE 4.2 U.S. Agricultural Production by Commodity (Sources: for 2018-2029, USDA 2020; for 2028-2050, this study) 
Projections of agricultural production by commodity were translated into $\mathrm{N}$ fertilizer demand using $\mathrm{N}$ fertilizer efficiencies (in lb crop/lb N). The USDA's National Agricultural Statistics Service (NASS) database provides yields per acre and fertilizer application rates in lb/acre (USDA 2017). To be conservative, the present study assumed that yields of agricultural products will increase in accordance with previous yield changes, while $\mathrm{N}$ fertilizer application rates will remain constant in the future.

Figure 4.3 shows historic yields of 16 types of agricultural commodities from at least 2000 through 2015 (USDA 2017). Citrus fruits include grapefruits, lemons, oranges, tangelos, and tangerines. Non-citrus fruits include apples, apricots, blueberries, cherries, coffee, figs, grapes, kiwifruit, nectarines, olives, peaches, pears, plums, prunes, and strawberries. Fresh market vegetables include asparagus, broccoli, cabbage, carrots, cauliflower, celery, cucumbers, fresh market garlic, lettuce, romaine, melons, cantaloupes, watermelons, onions, bell peppers, pumpkins, spinach, squash, sweet corn, and tomatoes. Processing vegetables include cabbages, carrots, cucumbers, spinach, sweet corn, and tomatoes. Pulses include green beans and peas. For each of these categories, linear regression functions were developed to represent yield increases over time. The $\mathrm{N}$ fertilizer application rates associated with these yields were obtained from the NASS database by averaging historic application rates for each crop, as presented in Table 4.1.

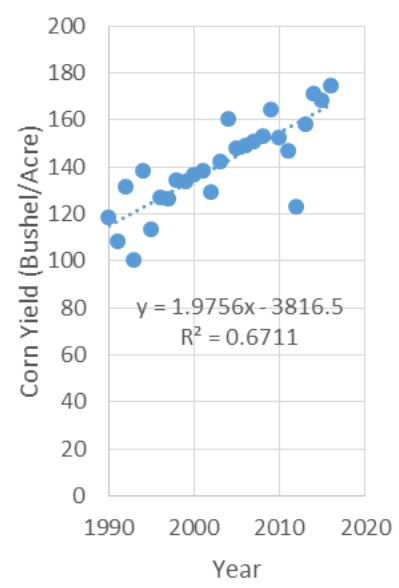

(a) Corn

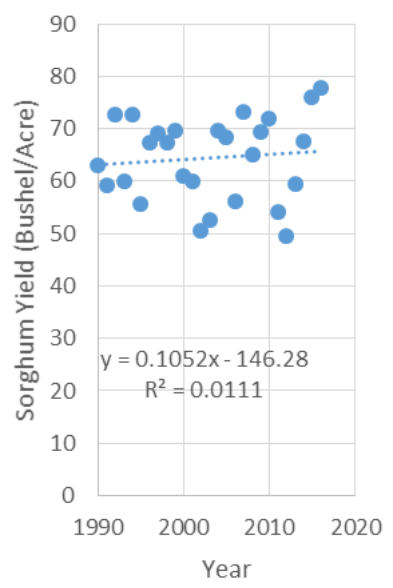

(b) Sorghum

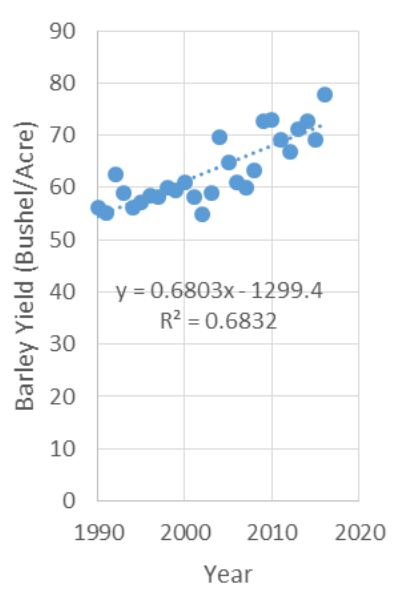

(c) Barley

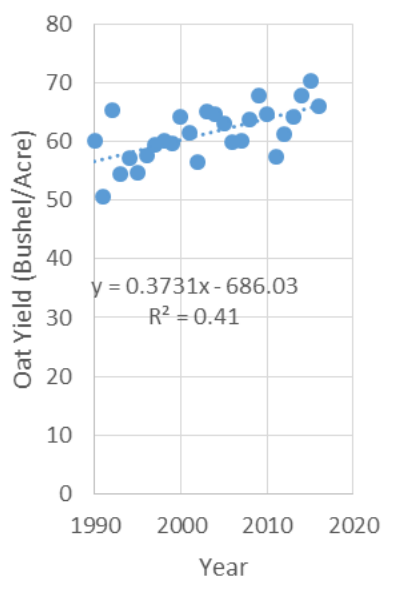

(d) Oats

FIGURE 4.3 Historic Yields of Agricultural Commodities (continues on next page) 


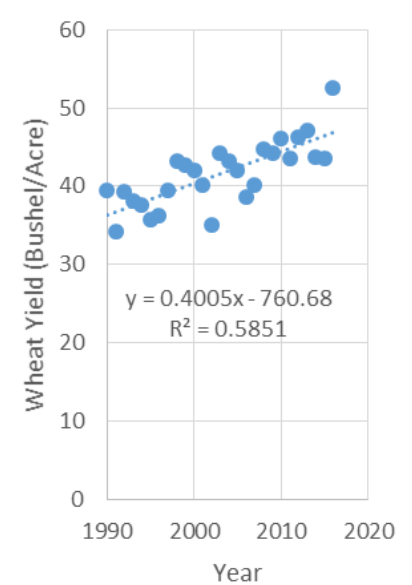

(e) Wheat Year

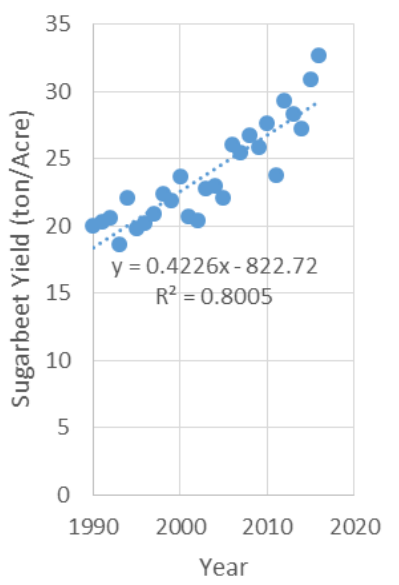

(i) Sugarbeets

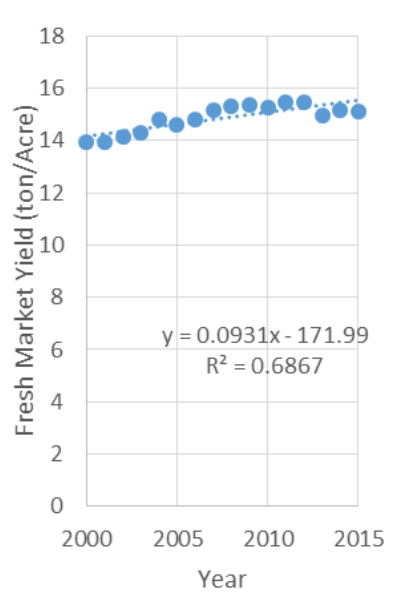

(m) Fresh Market Vegetables

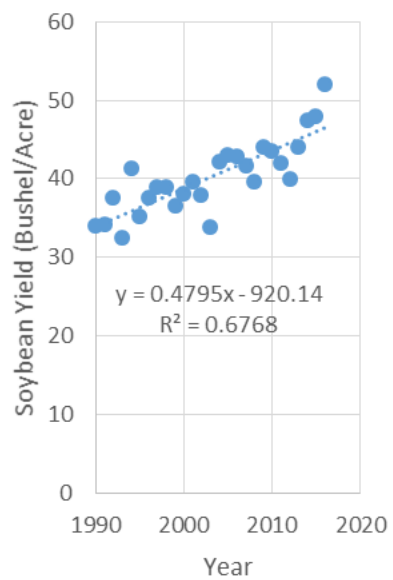

(f) Soybeans

Year

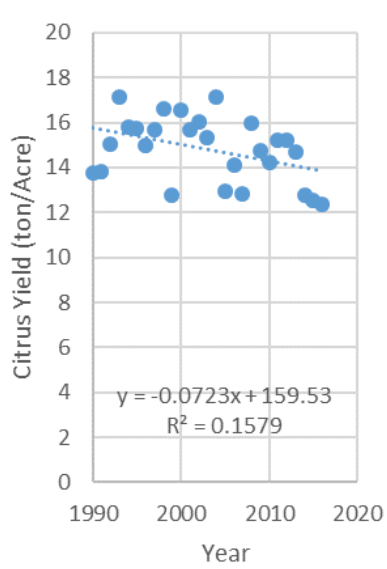

(j) Citrus Fruits

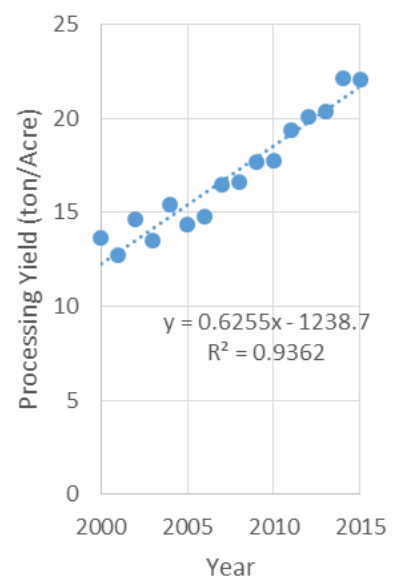

(n) Processing Vegetables

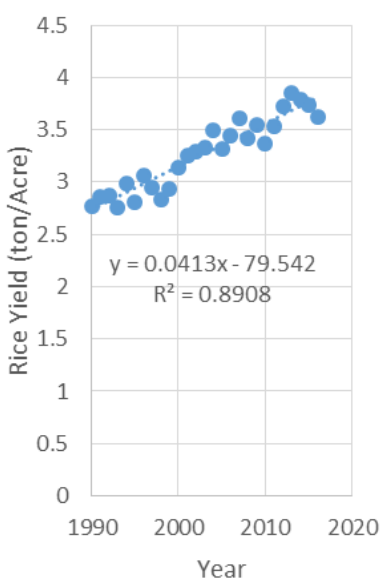

(g) Rice

Year

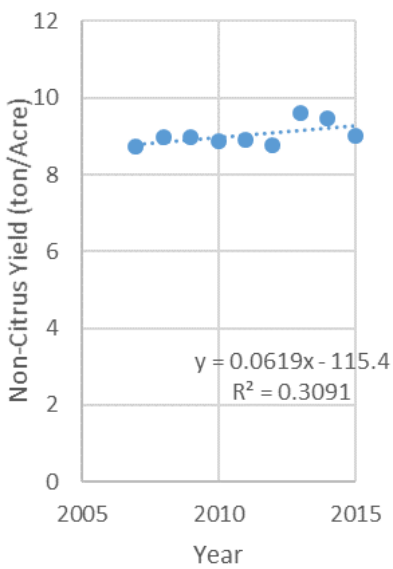

(k) Non-Citrus Fruits

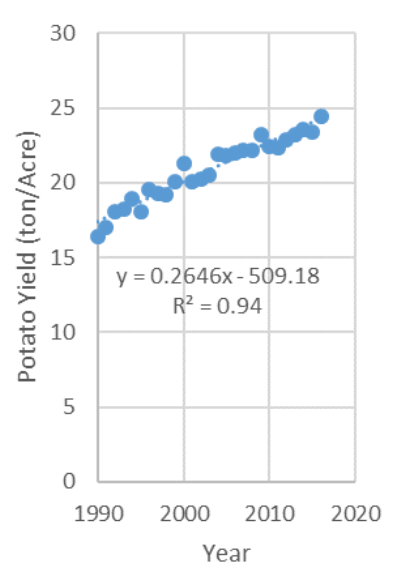

(o) Potatoes

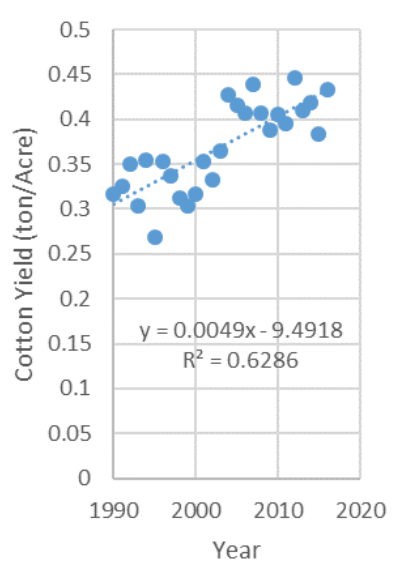

(h) Cotton Year

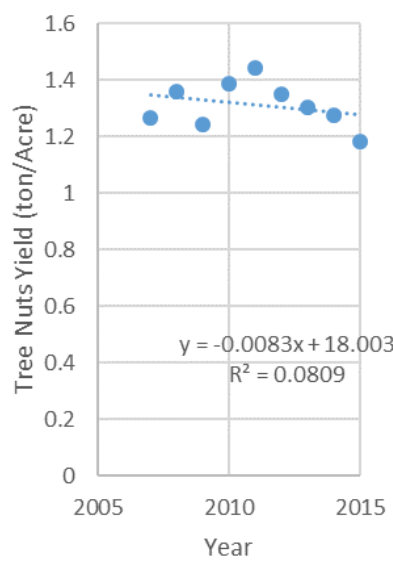

(1) Tree Nuts

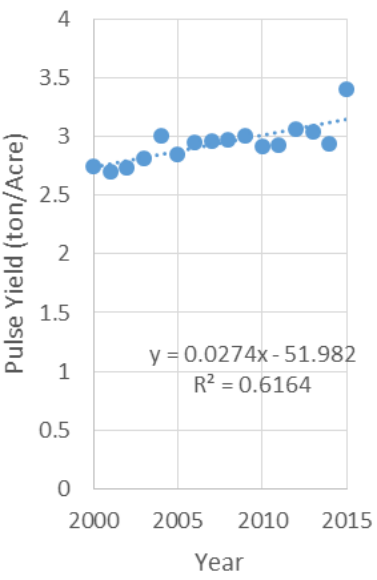

(p) Pulse

\section{FIGURE 4.3 Historic Yields of Agricultural Commodities}


TABLE 4.1 Average N Fertilizer Application Rates Derived from the USDA NASS Database (USDA 2017)

\begin{tabular}{l|cccc}
\hline Product & Corn & Sorghum & Barley & Oats \\
Rate $(\mathrm{lb} \mathrm{N} /$ acre) & 130 & 63.6 & 60.5 & 28.4 \\
\hline Product & Wheat & Soybeans & Rice & Cotton \\
Rate (lb N/acre) & 82.3 & 4.66 & 151 & 80.7 \\
\hline Product & Sugarbeets/Sugarcane & Citrus Fruits & Non-Citrus Fruits & Tree Nuts \\
Rate (lb N/acre) & 106 & 172 & 36.7 & 126 \\
\hline Product & Fresh Market Vegetables & Processing Vegetables & Potatoes & Pulse \\
Rate (lb N/acre) & 191 & 156 & 216 & 61.0 \\
\hline
\end{tabular}

$\mathrm{N}$ fertilizer demands were then estimated using projections of agricultural commodity production in the United States (Figure 4.2) and yields of food crops (Figure 4.3), along with average fertilizer application rates (Table 4.1). Table 4.2 provides the resulting $\mathrm{N}$ fertilizer use for corn, cotton, soybeans, wheat, and other commodities in 2011 estimated by the present study, which are checked against the USDA's estimated N fertilizer demands in 2011 (USDA 2017). The USDA's estimated $\mathrm{N}$ fertilizer demand includes the combined demand by other commodities and other plants. Because the present study does not estimate the demand by other plants, the demand by other plants is assumed constant at 3.58 million short tons per year, that is, the combined demand estimated by USDA (4.85 million short tons) minus the demand by other commodities estimated in the present study (1.27 million short tons). These results are in close alignment with those of the USDA.

TABLE 4.2 U.S. Plants' N Fertilizer Demands in 2011 Estimated by USDA and the Present Study (million short tons)

\begin{tabular}{|c|c|c|c|c|c|c|}
\hline & Corn & Cotton & Soybeans & Wheat & $\begin{array}{c}\text { Other } \\
\text { Commodities }\end{array}$ & Other Plants \\
\hline & \multicolumn{6}{|c|}{ million short tons } \\
\hline USDA & 5.61 & 0.38 & 0.11 & 1.33 & \multicolumn{2}{|c|}{4.85} \\
\hline This Study & 5.25 & 0.44 & 0.18 & 2.05 & 1.27 & $3.58 *$ \\
\hline
\end{tabular}

* $\mathrm{N}$ fertilizer demand by other plants (3.58 million short tons) is the balance of demand by other commodities plus other plants estimated by USDA (4.85 million short tons) and those by other commodities estimated in the present study (1.27 million short tons).

The USGS estimated total U.S. $\mathrm{NH}_{3}$ consumption in 2016 at 15 million short tons of $\mathrm{N}$ (13.6 MMT). As mentioned earlier, $12 \%$ of $\mathrm{NH}_{3}$ consumption (1.8 million short tons or 1.6 MMT) in the United States is for production of non-agricultural products. A scenario of no growth in non-agricultural products requires that the 1.8 million short tons of $\mathrm{NH}_{3}$ demand remain constant in the future.

Our projections of $\mathrm{NH}_{3}$ demand by commodity crops and other applications are shown in Figure 4.4. In general, $\mathrm{NH}_{3}$ demand is estimated to decrease slightly in the future owing to an 
increase in $\mathrm{N}$ fertilizer efficiency. The largest consumers of $\mathrm{NH}_{3}$ are fertilizers for corn farming, followed by fertilizers for other plants. The $\mathrm{N}$ fertilizer demand by corn is dominating because of the large amount of corn production in the United States.

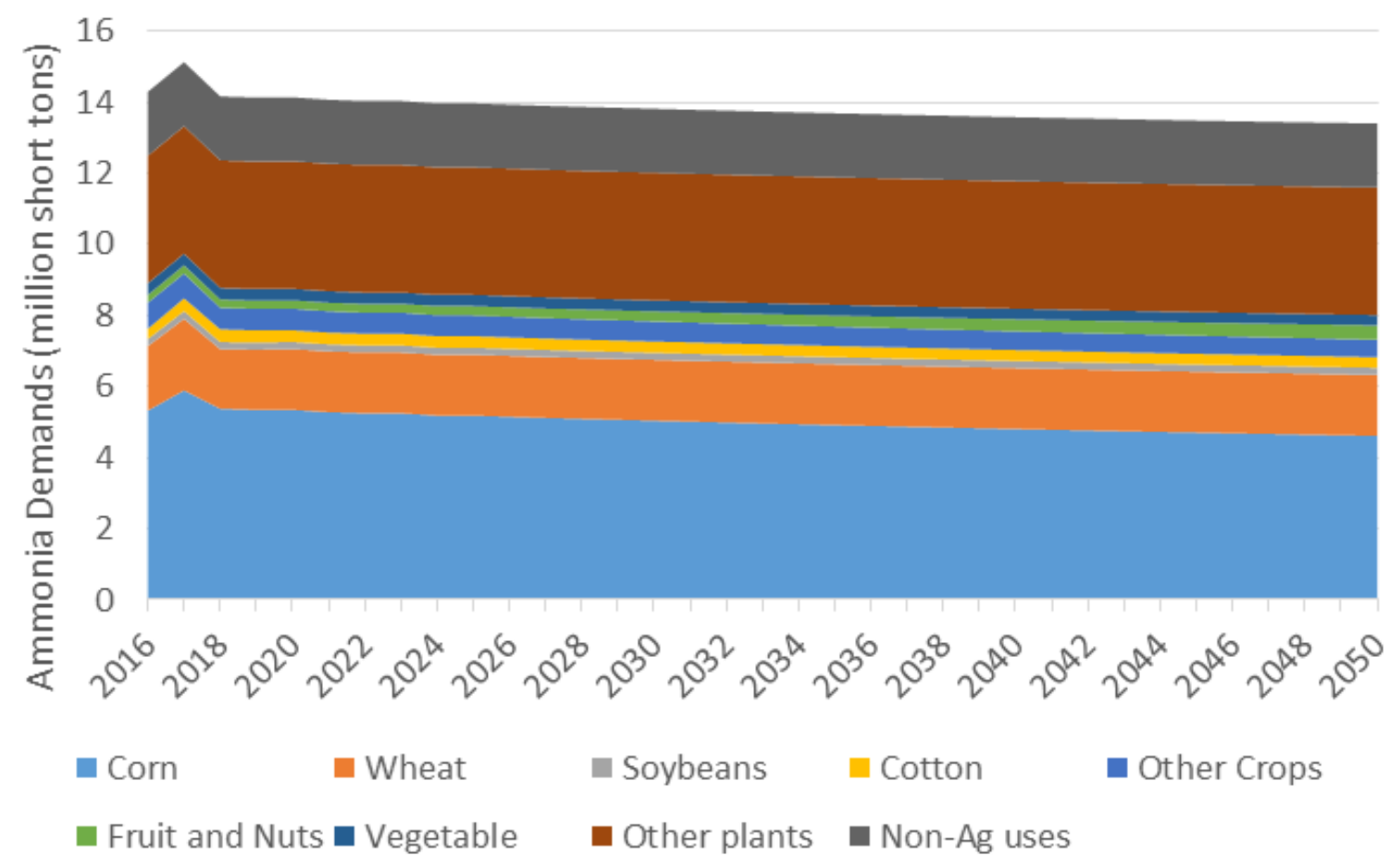

FIGURE 4.4 Projection of $\mathrm{NH}_{3}$ Demand by Crops and Other Applications

Among the 15 million short tons (13.6 MMT) of domestic $\mathrm{NH}_{3}$ consumption in 2016, the USGS estimated that 10.8 million short tons (9.8 MMT) were produced domestically, while 4.2 million short tons (3.8 MMT) were imported. Figure 4.5 shows U.S. $\mathrm{NH}_{3}$ production, imports, and exports (in thousand metric tons [MT] of N) through 2015 (USGS 2018). The origins of imported $\mathrm{NH}_{3}$ include Trinidad and Tobago (61\%), Canada (19\%), Russia (7\%), and Ukraine (5\%). 


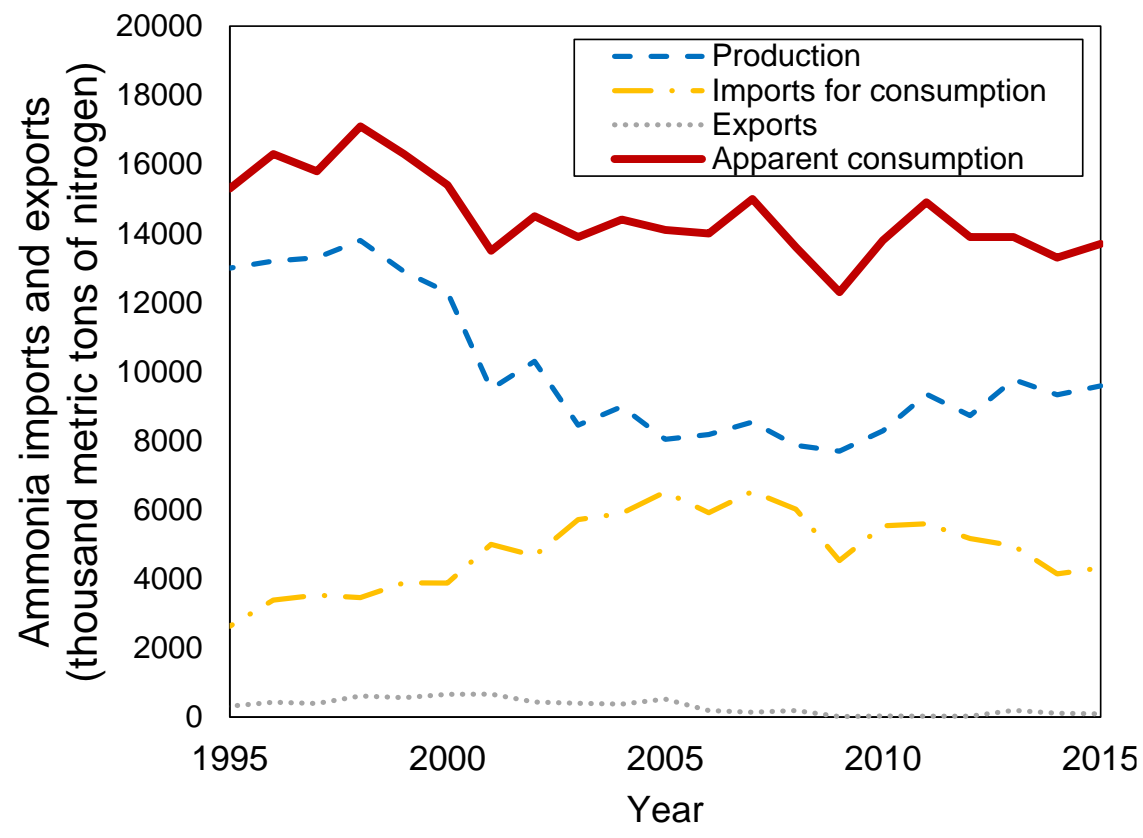

FIGURE 4.5 $\mathrm{NH}_{3}$ Production, Imports, and Exports (in Thousand Metric Tons of N) (USGS 2018)

According to the USGS (2017), the U.S. is the world's fourth-largest producer of $\mathrm{NH}_{3}$ (see Table 4.3). Depending on the cost of domestic $\mathrm{NH}_{3}$ production and the global price of $\mathrm{NH}_{3}$, the United States could become an exporter of $\mathrm{NH}_{3}$ and its derivatives. Global $\mathrm{NH}_{3}$ prices have been fairly consistent historically across regions (Jobity 2013; Argus Media 2016); thus, lowcost domestic production of $\mathrm{NH}_{3}$ could compete in the global marketplace. Figure 4.6 shows the prices of $\mathrm{NH}_{3}$, corn, and $\mathrm{NG}$ by region. As shown in the figure, $\mathrm{NH}_{3}$ price closely correlates with corn and NG prices; this result occurs because NG is used to produce hydrogen, which is a critical feedstock in ammonia production.

Production of low-cost hydrogen could enable an increase in $\mathrm{NH}_{3}$ production for both domestic and export markets. As shown in Figure 4.7, U.S. imports of $\mathrm{NH}_{3}$ are directly correlated with the price of NG, which influences the price of hydrogen (EIA 2018; USGS 2018). Thus, the production of low-cost hydrogen (through SMR of NG, water electrolysis, or any other technology) could enable growth in domestic $\mathrm{NH}_{3}$ production, displacing imports even without an increment in fertilizer demand. If the amount of currently imported $\mathrm{NH}_{3}$ were produced in the United States instead, domestic production could be increased by approximately $30 \%$ without a corresponding increase in domestic $\mathrm{NH}_{3}$ demand. 
TABLE 4.3 Top $10 \mathrm{NH}_{3}$-Producing Countries in 2016 (thousand MT)

\begin{tabular}{cccccccccc}
\hline China & Russia & India & United States & Indonesia & $\begin{array}{c}\text { Trinidad and } \\
\text { Tobago }\end{array}$ & $\begin{array}{c}\text { Saudi } \\
\text { Arabia }\end{array}$ & Canada & Qatar & Pakistan \\
\hline \multicolumn{10}{c}{ Thousand MT } \\
\hline 6,000 & 12,000 & 11,000 & 9,800 & 5,000 & 4,700 & 4,100 & 4,000 & 3,000 & 2,700 \\
\hline
\end{tabular}

Source: USGS (2017).

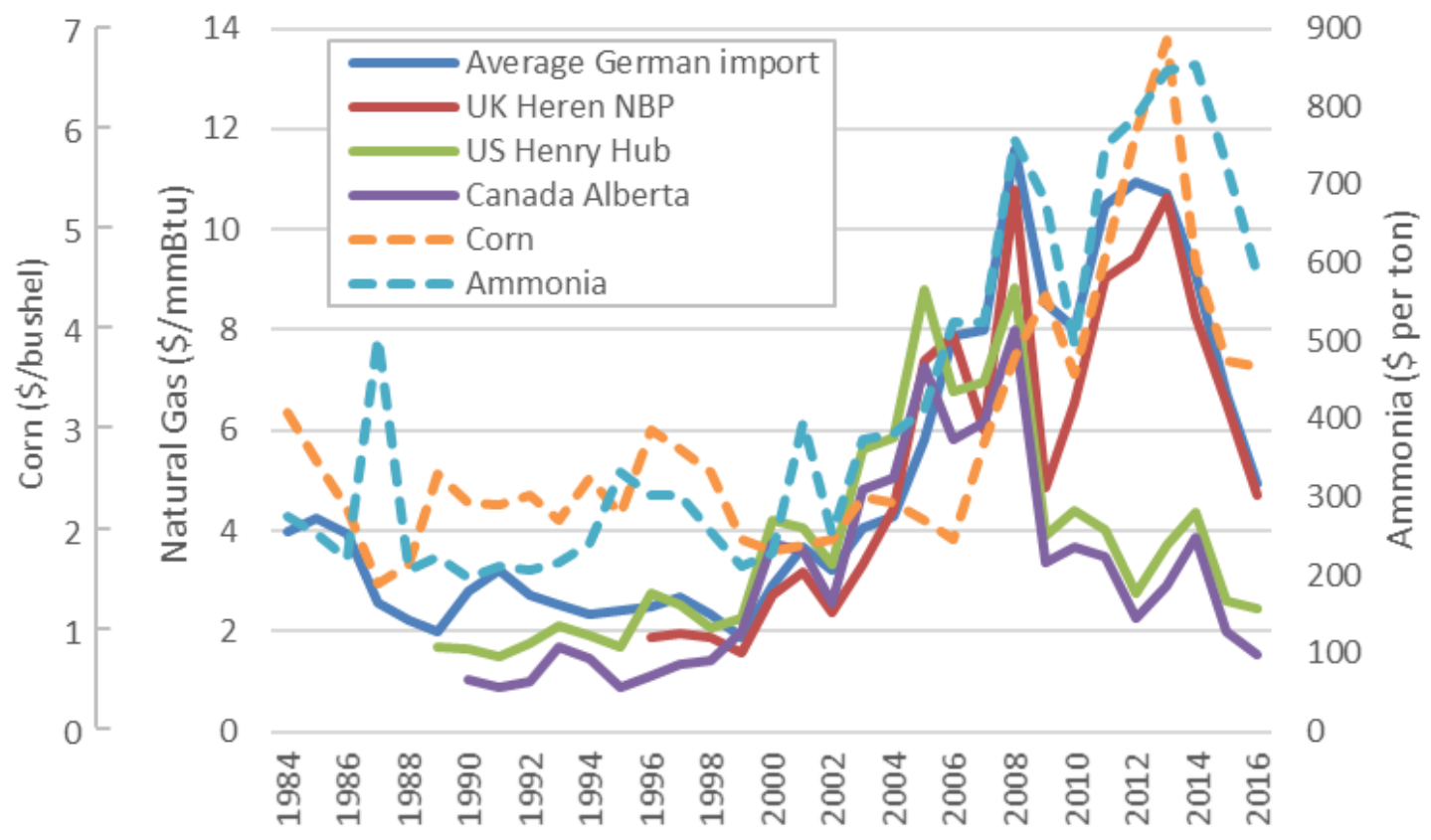

FIGURE 4.6 Price of $\mathrm{NH}_{3}$ and Corn in the United States, and Price of NG by World Region (Sources: Schnitkey 2016; BP 2017) 


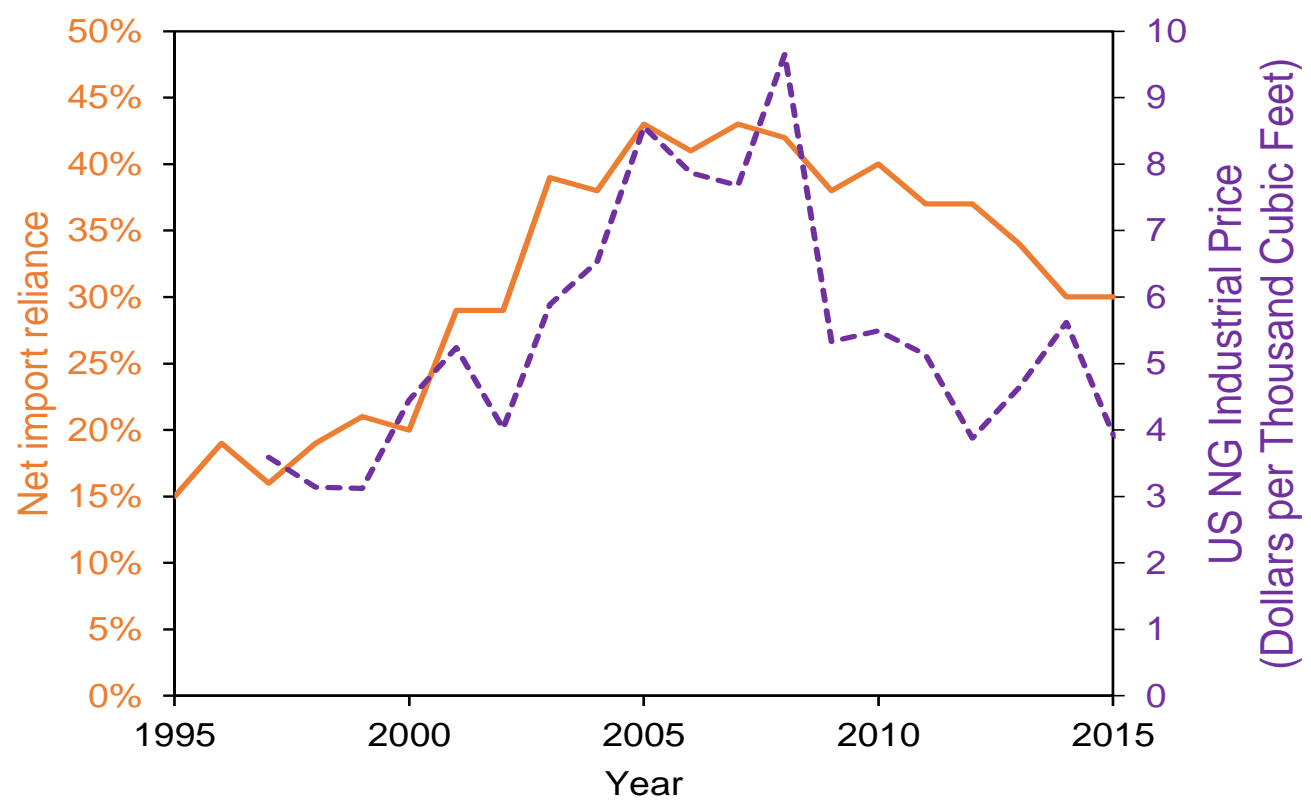

FIGURE 4.7 Net Import Reliance of U.S. $\mathrm{NH}_{3}$ Production and U.S. NG Industrial Price (EIA 2018; USGS 2018)

\subsection{Regional Hydrogen Demand for Ammonia Production}

One goal of the present study is to evaluate hydrogen demand by region to understand the proximity of hydrogen supply and demand within the $\mathrm{H} 2 @$ Scale assessment. To do so, we first acquired data on existing and planned $\mathrm{NH}_{3}$ plants in North America, including in the United States (Ammonia Industry 2018). The Ammonia Industry dataset includes production capacity of existing plants, as well as plans for new plants and expansion projects that have been announced by the industry. On the basis of the most recent dataset (November 2018), it is estimated that $\mathrm{NH}_{3}$ production capacity in the United States will increase $\sim 25 \%$ by 2024 relative to 2017 when "possible and likely" plans are considered (these are projects that have sufficient investment commitment or have already started construction). Using that forecast and extrapolating it further resulted in hydrogen demand for $\mathrm{NH}_{3}$ production estimates for 2017 , 2024 , and 2050 of 2.5, 3.1, and 3.6 MMT, respectively, assuming a modest $15 \%$ capacity growth between 2024 and 2050. In Figure 4.8, we show estimated growth in hydrogen demand to support those production levels, assuming the stoichiometric ratio of $\mathrm{NH}_{3}: \mathrm{H}_{2}$ is 2:3 (2 moles of $\mathrm{NH}_{3}$ production requires 3 moles of hydrogen) and an $80 \%$ capacity factor for U.S. ammonia plants. 


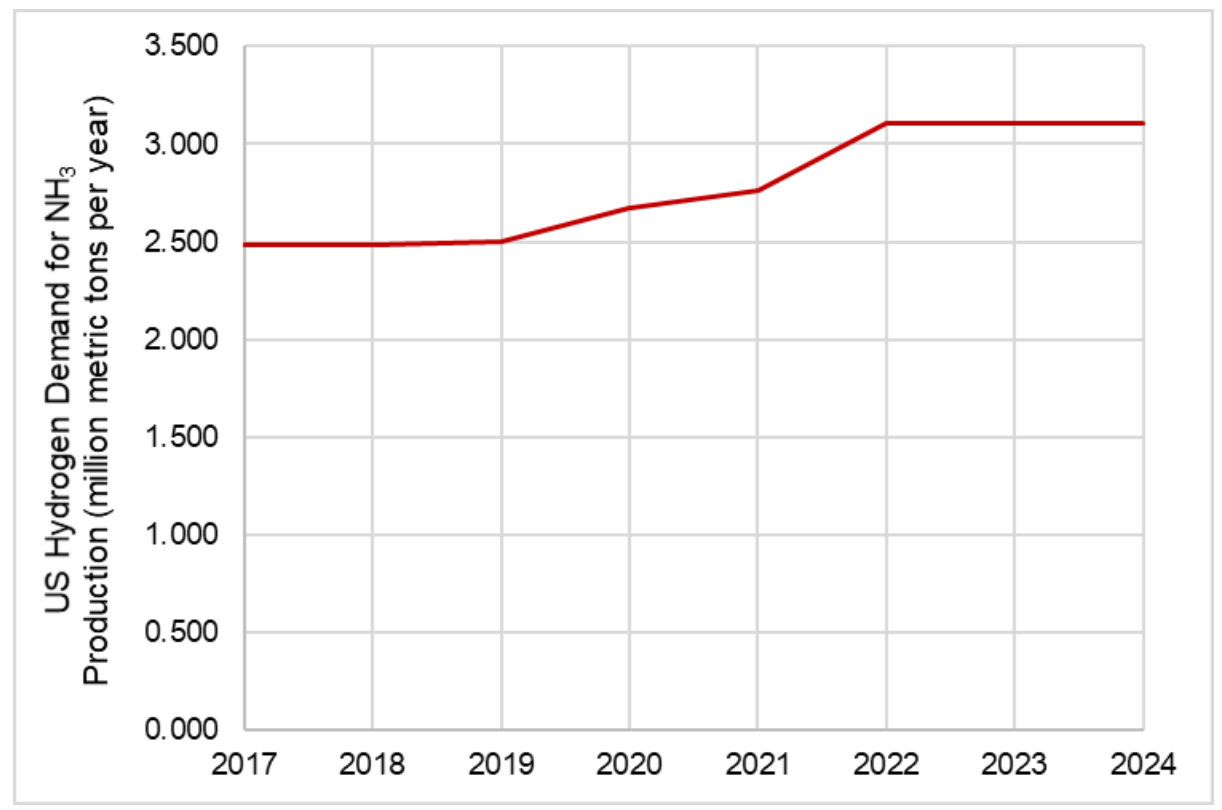

FIGURE 4.8 Current and Projected Hydrogen Demand for U.S. $\mathrm{NH}_{3}$ Production (Based on Data from Ammonia Industry [2018] through 2024)

Figure 4.9 shows the geographic distribution and relative size of hydrogen demand in support of 2017 U.S. $\mathrm{NH}_{3}$ production. The figure is developed from Ammonia Industry (2018) estimates, as they are more recent and more detailed (with plant-level data) than those of the USGS. As stated previously, hydrogen input to ammonia production is almost exclusively via SMR of NG. For hydrogen production via LTE and HTE of water (using solar, wind, and nuclear sources) to grow and capture new markets, production cost must be competitive with hydrogen production via NG SMR. 


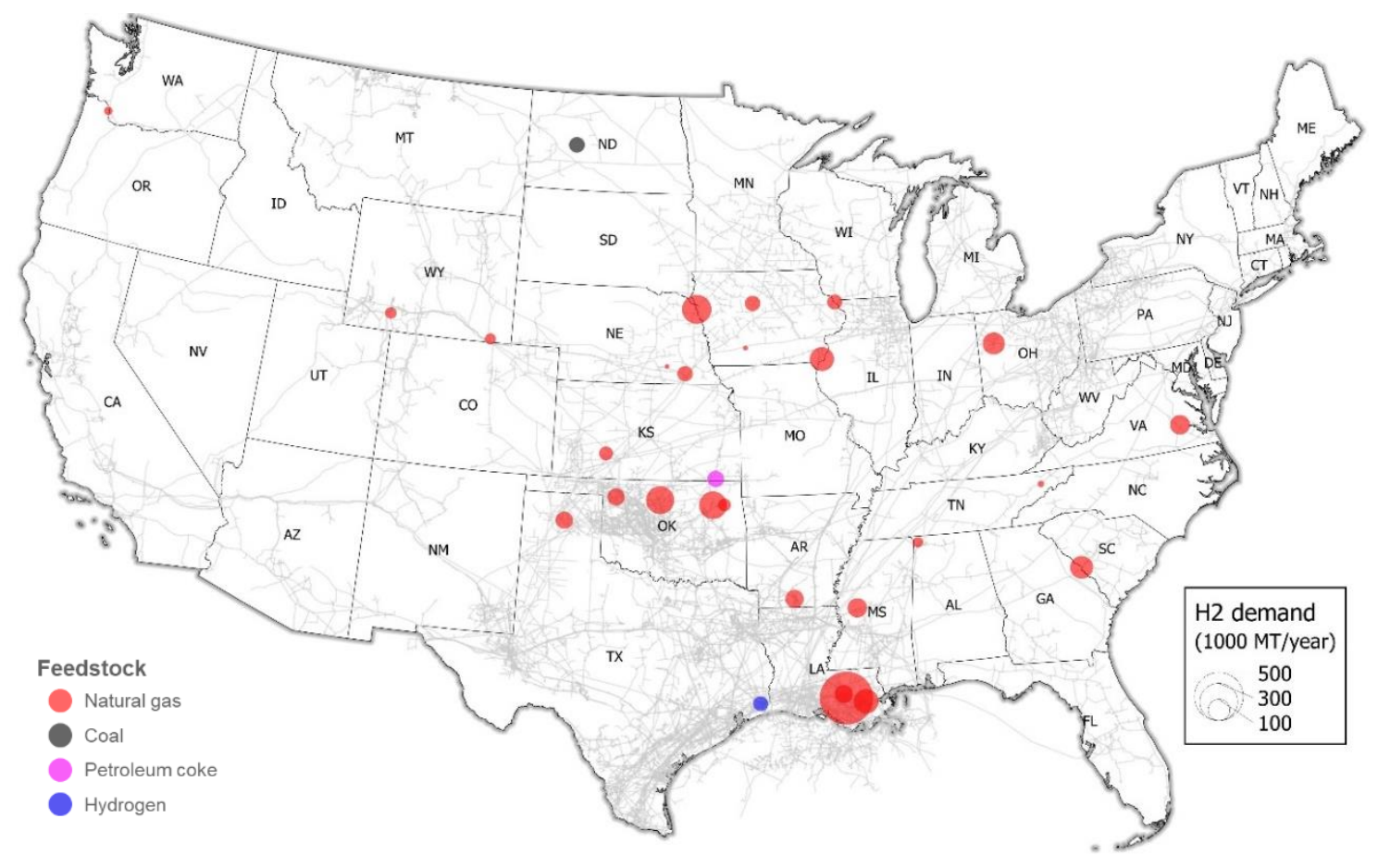

FIGURE 4.9 Estimated Hydrogen Demand for U.S. NH3 Production in 2017

As mentioned earlier, $\mathrm{NH}_{3}$ is the building block for many types of $\mathrm{N}$ fertilizers, such as anhydrous $\mathrm{NH}_{3}$, urea, urea ammonium nitrate (UAN), ammonium nitrate, and ammonium sulfate (see Figure 4.10). In general, the type of $\mathrm{N}$ fertilizer best suited for a given application will maximize absorption by the fertilized plant and minimize $\mathrm{N}$ loss to the atmosphere, while providing safety and ease in transportation, all of which depend on the application conditions and preferences. Table 4.4 summarizes the key features, along with the pros and cons of various $\mathrm{N}$ fertilizers used in the United States (Weiss et al. 2009).

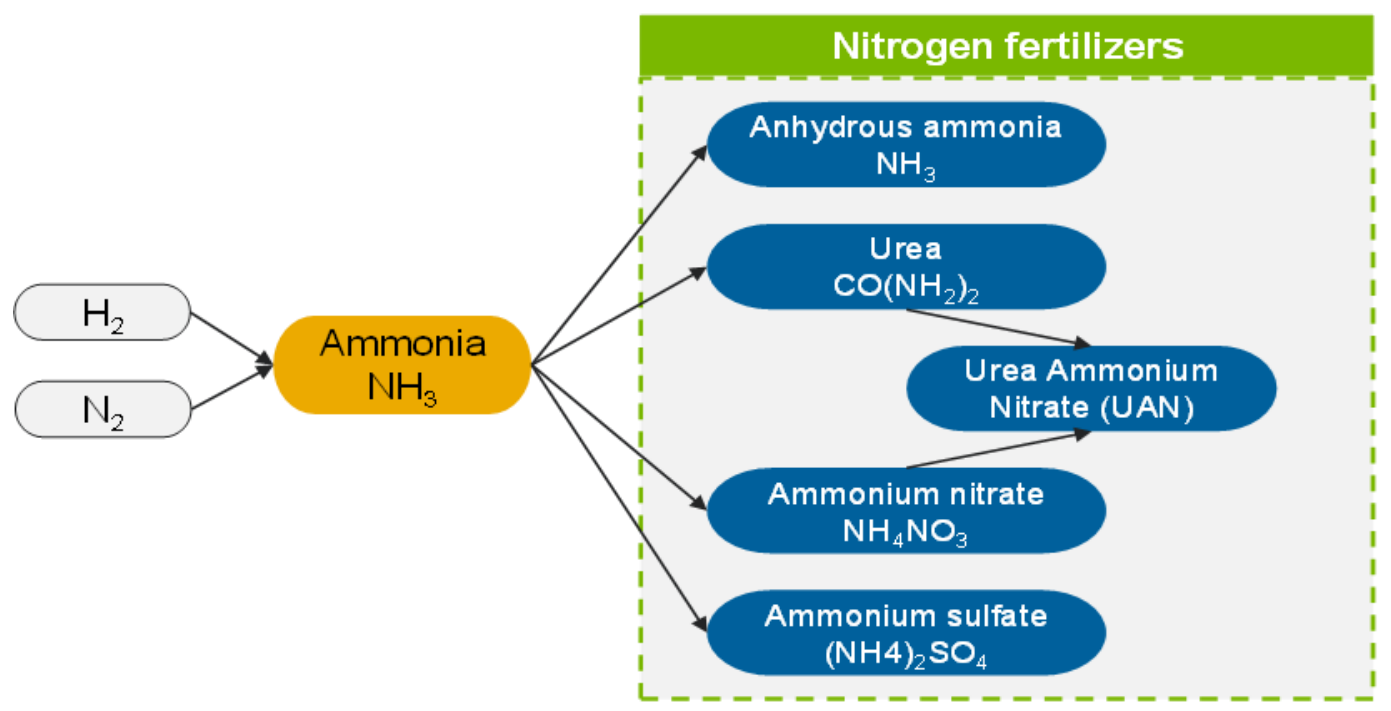

FIGURE 4.10 Types of Nitrogen Fertilizers Used in the United States 
TABLE 4.4 Properties, Market Shares, and Prices of N Fertilizers

\begin{tabular}{|c|c|c|c|c|c|c|}
\hline Fertilizer & Phase & $\begin{array}{c}\mathrm{N} \\
(\mathrm{wt} \%)\end{array}$ & $\begin{array}{c}2014 \\
\text { U.S. Share }^{\mathrm{a}} \\
(\%)\end{array}$ & $\begin{array}{l}\text { Price }^{\mathrm{a}} \\
\text { (\$/ton) }\end{array}$ & $\begin{array}{c}\text { Price }^{\mathrm{a}} \\
\text { (\$/N ton) }\end{array}$ & $\begin{array}{c}\text { Pros and Cons } \\
\text { (Weiss et al. 2009) }\end{array}$ \\
\hline $\begin{array}{c}\text { Anhydrous } \\
\mathrm{NH}_{3}\end{array}$ & $\begin{array}{l}\text { Liquid } \\
\text { (at high } \\
\text { pressure) }\end{array}$ & 82 & 14 & 851 & 1,038 & $\begin{array}{l}\text { + Highest } \mathrm{N} \% \text { and cheapest } \mathrm{N} \text { source } \\
\text { - Toxic } \\
\text { - Must be injected 6-8 inches deep to avoid N loss } \\
\text { - Requires high-pressure storage for transport and handling } \\
\text { - Personal protective equipment should be used }\end{array}$ \\
\hline Urea & Solid & 46 & 24 & 571 & 1,269 & $\begin{array}{l}\text { + High } \mathrm{N} \text { content, low cost per lb of } \mathrm{N} \\
+ \text { Non-toxic } \\
\text { + Safe transportation and handling } \\
\text { + Rapid conversion to plant-available } \mathrm{N} \\
\text { - N losses to the air can approach } 40 \% \text { of the applied } \mathrm{N} \\
\text { - Rapid pH increase after application can damage seedlings }\end{array}$ \\
\hline $\begin{array}{l}\text { Ammonium } \\
\text { nitrate }\end{array}$ & Solid & 35 & 3 & 560 & 1,600 & $\begin{array}{l}\text { + Contains both ammonium and nitrate, resulting in reduced volatilization } \\
+ \text { Nitrate provides a directly available N source } \\
\text { - Lowers pH of the soil } \\
\text { - Can be used to make explosives, and thus raises concerns for potential misuse } \\
\text { - Must adhere to safety guidelines for handling and storage }\end{array}$ \\
\hline $\begin{array}{l}\text { Ammonium } \\
\text { sulfate }\end{array}$ & Solid & 21 & 6 & 533 & 2,538 & $\begin{array}{l}+ \text { Soluble, readily available source of } \mathrm{N} \text { and } \mathrm{S} \\
+ \text { Lower } \mathrm{N} \text { volatilization risk (good for top-dress) } \\
\text { - High salt index and greater acidification potential per unit } \mathrm{N} \\
\text { - High cost per lb of } \mathrm{N} \text { and low } \mathrm{N} \text { content }\end{array}$ \\
\hline UAN & Liquid & $28-32$ & 44 & 359 & 1,197 & $\begin{array}{l}\text { + Non-pressurized liquid fertilizer } \\
+ \text { Uniformity } \\
+ \text { Volatilization loss per lb of } \mathrm{N} \text { is lower than urea } \\
+ \text { Ease of storage, handling, and application } \\
\text { - Lowers pH of soil }\end{array}$ \\
\hline
\end{tabular}

a Data source: USDA (2018). 
$\mathrm{NH}_{3}$ is a colorless and toxic gas at atmospheric conditions, and needs to be compressed and liquefied (i.e., to anhydrous $\mathrm{NH}_{3}$ ) to be injected into the soil. Because anhydrous $\mathrm{NH}_{3}$ has the highest $\mathrm{N}$ content ( $82 \%$ by weight) among $\mathrm{N}$ fertilizers, it is the lowest-cost option per unit of $\mathrm{N}$ (weight basis).

Urea, denoted as $\mathrm{CO}\left(\mathrm{NH}_{2}\right)_{2}$, is a non-toxic solid $\mathrm{N}$ fertilizer that can be produced by combining $\mathrm{NH}_{3}$ and $\mathrm{CO}_{2}$; it represented $24 \%$ of total $\mathrm{N}$ fertilizer use in 2014 . It has the highest $\mathrm{N}$ content (46\%) among solid $\mathrm{N}$ fertilizers, and the $\mathrm{N}$ is quickly converted into plant-available $\mathrm{N}$ once it is applied. It is also preferred for its safe transportation and handling. However, N loss from urea application can be up to $40 \%$, and it can increase soil $\mathrm{pH}$, which may cause damage to seedlings (Weiss et al. 2009). It is important to note that urea production requires the reaction of $\mathrm{CO}_{2}$ with $\mathrm{NH}_{3}$. Traditionally, $\mathrm{CO}_{2}$ from an $\mathrm{SMR}$ hydrogen plant is used to convert $\mathrm{NH}_{3}$ to urea. If hydrogen is instead produced by electrolysis, the ammonia plant would have to be located in close proximity to a low-cost supply of $\mathrm{CO}_{2}$, such as an ethanol plant.

Ammonium nitrate $\left(\mathrm{NH}_{4} \mathrm{NO}_{3}\right)$ and ammonium sulfate $\left.\left(\text { or } \mathrm{NH}_{4}\right)_{2} \mathrm{SO}_{4}\right)$ are both solid fertilizers and are generated by combining $\mathrm{NH}_{3}$ with nitric acid $\left(\mathrm{HNO}_{3}\right)$ and sulfuric acid $\left(\mathrm{H}_{2} \mathrm{SO}_{4}\right)$, respectively. As ammonium nitrate is more stable than urea, it does not rapidly lose $\mathrm{N}$ to the atmosphere. However, ammonium nitrate can be used to make explosives and requires adherence to strict safety guidelines for handling and storage. Ammonium sulfate has a relatively low $\mathrm{N}$ content and is generally more expensive than other $\mathrm{N}$-fertilizers, but it provides $\mathrm{S}$, which is essential for crop production.

UAN, a liquid fertilizer that is a mixture of urea, ammonium nitrate, and water, represented $44 \%$ of total $\mathrm{N}$ fertilizer use in 2014 . Depending on the shares of components in the mixture, $\mathrm{N}$ concentration by weight can vary from $28 \%$ to $32 \%$. UAN can be easily applied to soil by spraying it or adding it to irrigation water; it also has relatively low volatilization compared to urea, accounting for its wide use in the United States.

Figure 4.11 displays $\mathrm{N}$ fertilizer consumption (by mass) in the United States over time (USDA 2018). Clearly, overall use (green curve) has grown dramatically. In 2014, total N fertilizer consumption in the United States was estimated at 27.9 million tons (total fertilizer products), which is six times higher than their use in 1960 (4.5 million tons). UAN and urea shares of total $\mathrm{N}$ fertilizer use have increased, to $44 \%$ and $24 \%$, respectively, in 2014. Although anhydrous $\mathrm{NH}_{3}$ was the most popular $\mathrm{N}$ fertilizer in the early 1970 s at $30 \%$ of $\mathrm{N}$ fertilizer consumption, its share in 2014 was estimated to have dropped to just $14 \%$. 


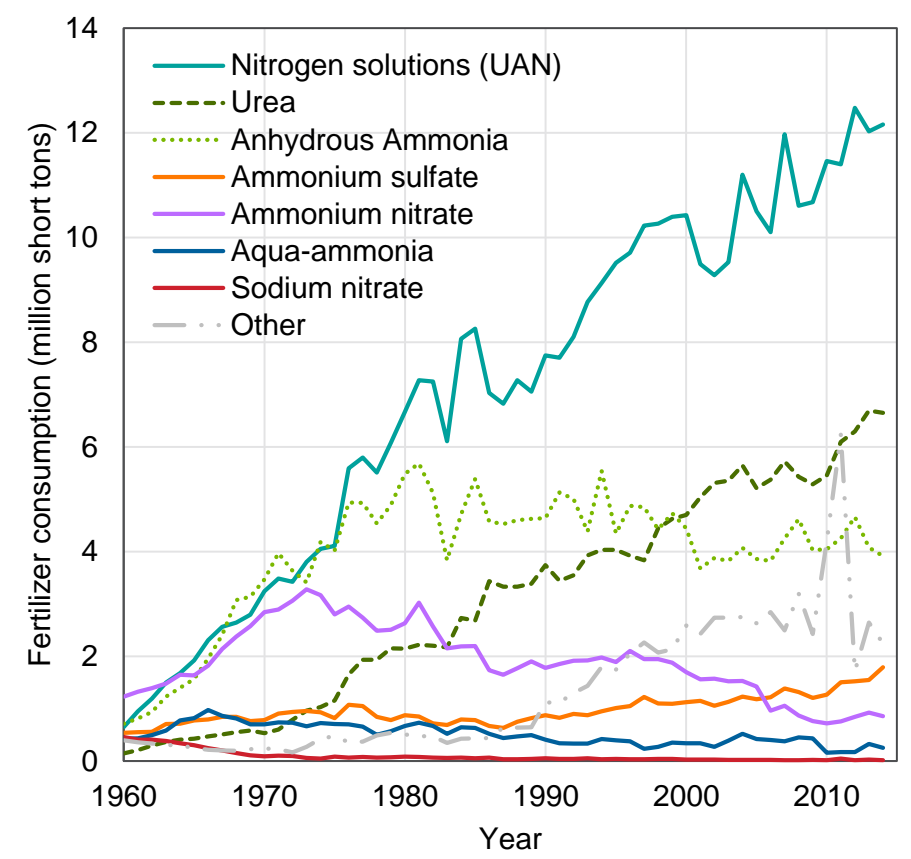

2014 N Fertilizer Share (by mass)

\begin{tabular}{cc}
\hline Nitrogen solutions (UAN) & $44 \%$ \\
Urea & $24 \%$ \\
Anhydrous $\mathrm{NH}_{3}$ & $14 \%$ \\
Ammonium sulfate & $6 \%$ \\
Ammonium nitrate & $3 \%$ \\
Aqua-NH & $1 \%$ \\
Other & $8 \%$ \\
\hline
\end{tabular}

FIGURE 4.11 U.S. Consumption of Nitrogen Fertilizers and Shares by Type in 2014 (USDA 2018)

\subsection{References}

Ammonia Industry, 2018. "Ammonia Capacity in North America." Available at https://ammoniaindustry.com/download-ammonia-capacity-in-north-america/, accessed July 12, 2020.

Argus Media, 2016. “Argus FMB Ammonia.” Available at http://www.argusmedia.com/ /media/files/pdfs/samples/argus-fmb-ammonia.pdf?la=en, accessed, 2020.

BP, 2017. BP Statistical Review of World Energy June 2017, London.

DOE (U.S. Department of Energy), 2018. DOE H2A Analysis. Available at https://www.hydrogen.energy.gov/h2a_analysis.html, accessed July 12, 2020.

EIA (U.S. Energy Information Administration), 2018. "Natural Gas: United States Natural Gas Industrial Price." Available at https://www.eia.gov/dnav/ng/hist/n3035us3m.htm, accessed July 12, 2020.

Jobity, R., 2013. "History and Role of the Natural Gas Industry," presented at the NGC/UTT Natural Gas Workshops 2013, Republic of Trinidad \& Tobago, August. 
Schnitkey, G., 2016. "Anhydrous Ammonia, Corn, and Natural Gas Prices over Time," Farmdoc Daily (6):112. Available at http://farmdocdaily.illinois.edu/2016/06/anhydrous-ammonia-cornand-natural-gas-prices.html, accessed July 12, 2020.

USDA (U.S. Department of Agriculture), 2017. "NASS-National Agricultural Statistics Service." Available at http://www.nass.usda.gov/index.asp, accessed July 12, 2020.

USDA, 2018. "Fertilizer Use and Price." Available at https://www.ers.usda.gov/dataproducts/fertilizer-use-and-price/, accessed July 12, 2020.

USDA, 2020. USDA Agricultural Projections to 2029. Available at https://www.ers.usda.gov/webdocs/outlooks/95912/oce-2020-1.pdf?v=3725.5, accessed July 12, 2020.

USGS (U.S. Geological Survey), 2017. Mineral Commodity Summaries 2017, National Minerals Information Center, Reston, VA. Available at https://minerals.usgs.gov/minerals/pubs/commodity/nitrogen/mcs-2017-nitro.pdf, accessed July 12, 2020.

USGS, 2018. "Minerals Information: Nitrogen Statistics and Information.” Available at https://minerals.usgs.gov/minerals/pubs/commodity/nitrogen/, accessed July 12, 2020.

Weiss, J., T. Bruulsema, M. Hunter, K. Czymmek, J. Lawrence, and Q. Ketterings, 2009. Agronomy Fact Sheet Series: Nitrogen Fertilizers for Field Crops, Cornell University Cooperative Extension. Available at http://db.nyfvi.org/documents/1664.pdf, accessed July 12, 2020. 


\section{SYNTHETIC FUEL AND CHEMICAL PRODUCTION VIA $\mathrm{CO}_{2}$ UTILIZATION}

Numerous synthetic fuels and chemicals can be produced when hydrogen reacts with $\mathrm{CO}_{2}$. Synthetic fuels can be of particular value in applications that require substantial, long duration power and high volumetric and gravimetric energy density; examples include long-haul trucking, rail, marine, and aviation applications. In addition, U.S. and international demand for specialty chemicals, such as methanol, is expected to grow in the near term. This growth could create additional demand for hydrogen.

The availability of concentrated supplies of $\mathrm{CO}_{2}$ can reduce the cost of producing synthetic fuels. While most of the 5 billion MT of annual $\mathrm{CO}_{2}$ emissions in the United States are dilute, approximately $100 \mathrm{MMT}$ of annual $\mathrm{CO}_{2}$ emissions occur in concentrated form. Sources for concentrated $\mathrm{CO}_{2}$ in the United States include ethanol plants and SMR (Figure 5.1). Out of the $100 \mathrm{MMT}$ of concentrated $\mathrm{CO}_{2}$, only $11 \mathrm{MMT}$ are currently sold into the merchant market for applications such as food processing and carbonated beverages (Supekar and Skerlos 2014). The remainder is released into the atmosphere. If captured and reacted with low-carbon hydrogen, that remaining 89 MMT could produce significant quantities of low-carbon synfuels and chemicals.
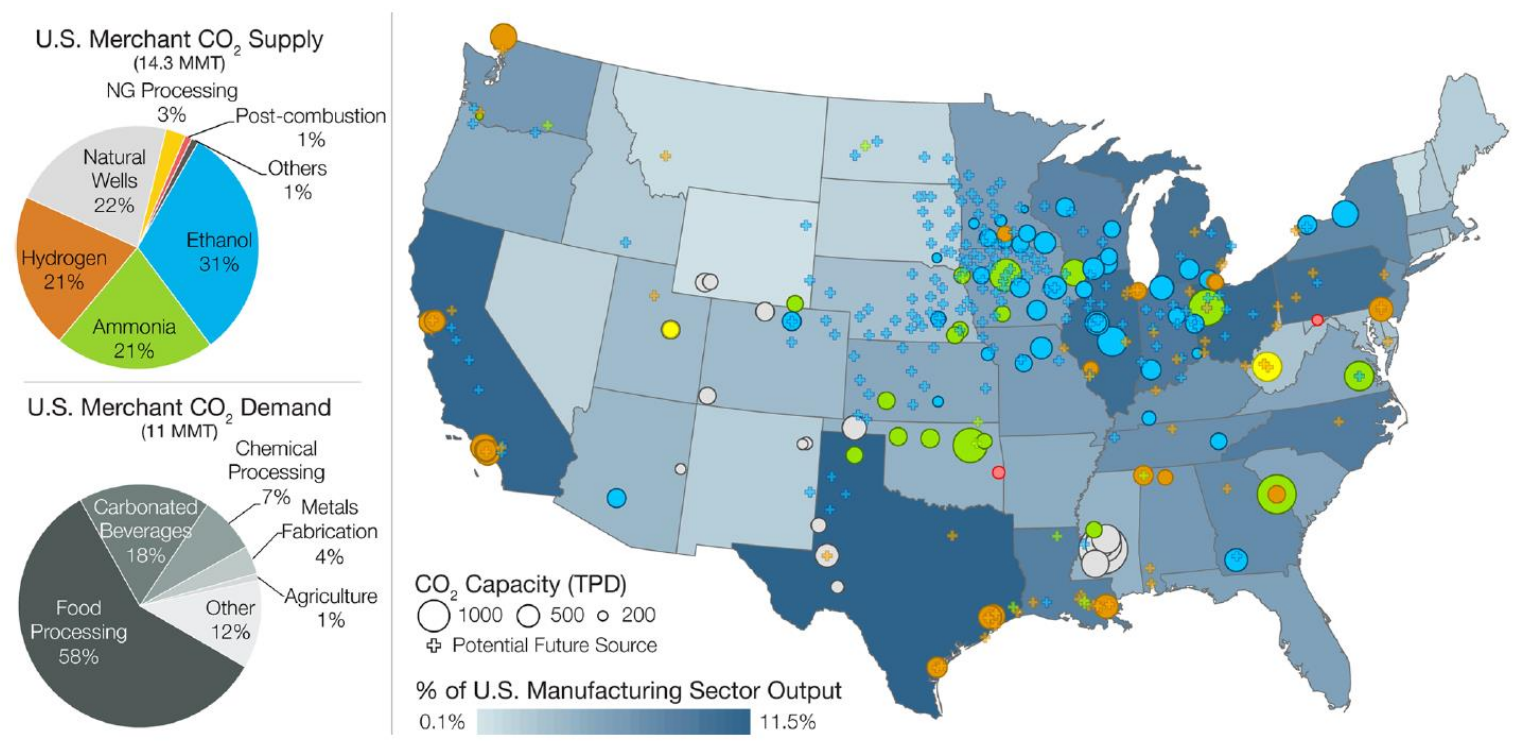

FIGURE 5.1 Sources of Concentrated $\mathrm{CO}_{2}$, and Current Supply and Demand of Merchant $\mathrm{CO}_{2}$ (Adapted with permission from Sarang D. Supekar and Steven J. Skerlos, Environmental Science \& Technology 2014, 48 (24), 14615-14623, Copyright 2014, American Chemical Society) 
Research and development (R\&D) is ongoing on a worldwide basis to enable lower-cost production of synfuels using $\mathrm{CO}_{2}$ that would otherwise be unutilized. For this analysis, potential $\mathrm{CO}_{2}$ recovery from three concentrated sources was estimated: ethanol plants, $\mathrm{NH}_{3}$ plants, and SMR hydrogen production plants. Then corresponding hydrogen demand for synfuel production was determined. Based on Tremel et al. (2015), stoichiometric synthesis requires 3 moles of hydrogen for each mole of $\mathrm{CO}_{2}$ in order to produce synfuels such as FT diesel or $\mathrm{MeOH}$ (two hydrogen moles to reduce the oxygen $\left(\mathrm{O}_{2}\right)$ in $\mathrm{CO}_{2}$, and one mole for $-\mathrm{CH}_{2}$ - in the synfuel hydrocarbon chain). In the present analysis, we used practical ratios of 3:1 to estimate potential hydrogen demand for methanol production, and 2.4:1 to estimate potential hydrogen demand for FT fuel production from $\mathrm{CO}_{2}$.

For this analysis, we assumed that $\mathrm{CO}_{2}$ emissions from ethanol, $\mathrm{NH}_{3}$, and $\mathrm{SMR}$ hydrogen plants are sufficiently concentrated for use in synfuel and methanol production. Estimates of $\mathrm{CO}_{2}$ emissions from $\mathrm{NH}_{3}$ and SMR plants were obtained from the U.S. Environmental Protection Agency (EPA 2017). However, because the EPA does not report data on concentrated $\mathrm{CO}_{2}$ emissions from the ethanol fermentation process, we estimated those based on the stoichiometric ratio between ethanol production and $\mathrm{CO}_{2}$, and ethanol production capacity at the facility level (EIA 2018). Stoichiometry shows that 1 mole of ethanol production via fermentation creates 1 mole of $\mathrm{CO}_{2}$ :

$$
\begin{gathered}
\mathrm{C}_{6} \mathrm{H}_{12} \mathrm{O}_{6} \text { (Glucose) } \rightarrow 2 \mathrm{CH}_{3} \mathrm{CH}_{2} \mathrm{OH}+2 \mathrm{CO}_{2} \\
\left.\mathrm{C}_{12} \mathrm{H}_{22} \mathrm{O}_{11} \text { (Sucrose }\right)+\mathrm{H}_{2} \mathrm{O} \rightarrow 4 \mathrm{CH}_{3} \mathrm{CH}_{2} \mathrm{OH}+4 \mathrm{CO}_{2}
\end{gathered}
$$

In 2017, ethanol operating production in the United States was estimated at 15.6 billion gallons (EIA 2018), and high-purity (recoverable) $\mathrm{CO}_{2}$ production from ethanol plants was estimated at $44 \mathrm{MMT}$, that is, about $44 \%$ of the three considered $\mathrm{CO}_{2}$ sources ( 100 MMT) in the United States. Concentrated $\mathrm{CO}_{2}$ emissions from SMR in refineries are of comparable magnitude to those from ethanol plants.

If all $100 \mathrm{MMT}$ of $\mathrm{CO}_{2}$ from ethanol, $\mathrm{NH}_{3}$, and $\mathrm{SMR}$ plants were used to produce synfuels, the maximum potential hydrogen demand can be estimated assuming a maximum of $100 \%$ carbon conversion efficiency and using the stoichiometric $3: 1 \mathrm{H}_{2} /\left(\mathrm{CO}_{2}\right)$ molar ratio. If all recoverable $\mathrm{CO}_{2}$ from these sources were utilized for synfuel production, the maximum annual supply of synfuels would be approximately 10 billion gallons. Production of this quantity of synfuels would create a maximum hydrogen demand of $14 \mathrm{MMT} / \mathrm{year}$. Of this $14 \mathrm{MMT} / \mathrm{year}$, 6 MMT hydrogen/year would be needed to convert all of the $\mathrm{CO}_{2}$ from ethanol plants into synfuels, 5.9 MMT $\mathrm{H}_{2}$ /year would be needed to convert all $\mathrm{CO}_{2}$ from refinery SMR plants into synfuels, and 2.1 MMT/year would be needed to convert all $\mathrm{CO}_{2}$ from $\mathrm{NH}_{3}$ plants into synfuels. The regional distribution of the 14 MMT of potential hydrogen demand is presented in Figure 5.2. 


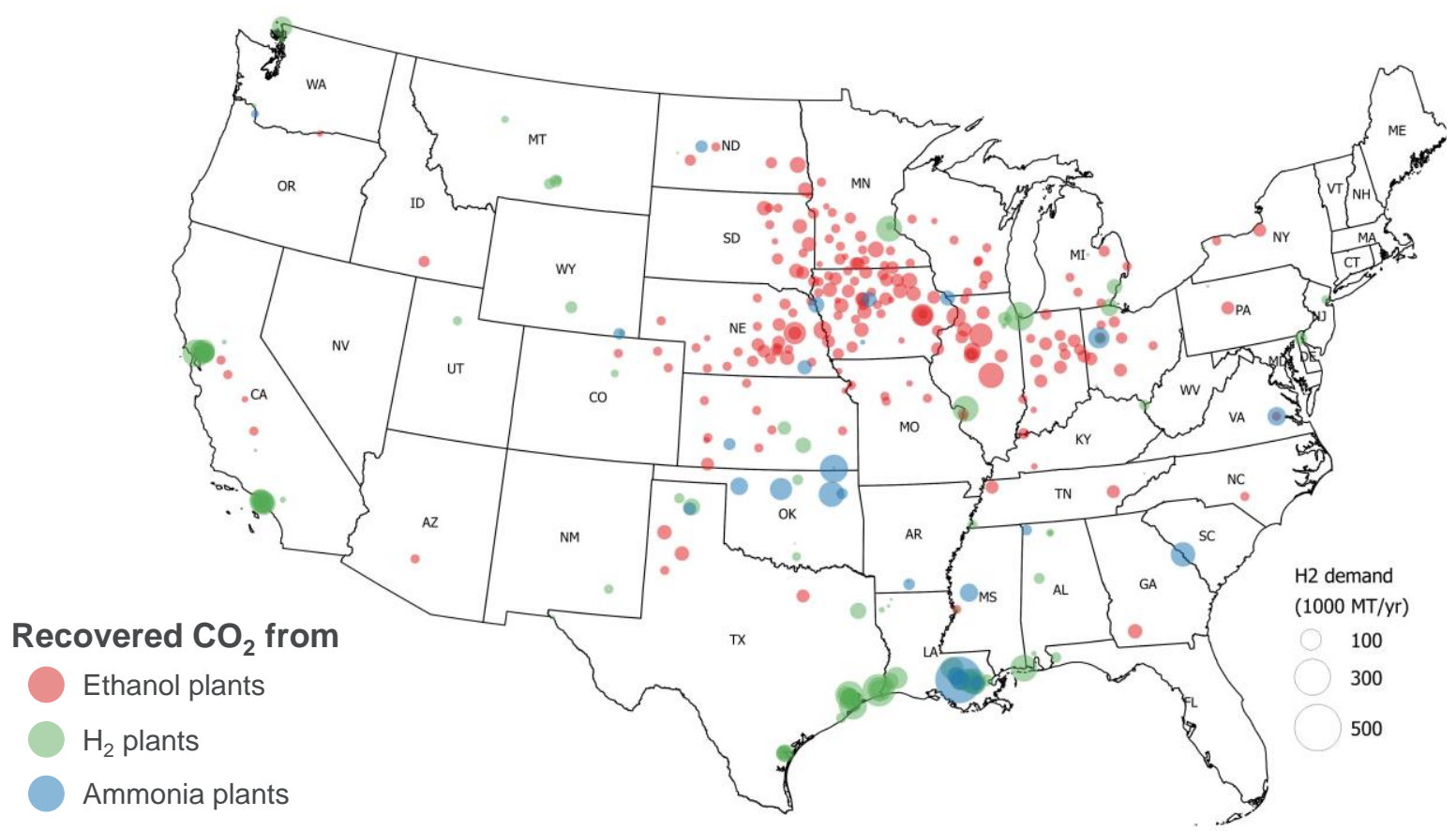

FIGURE 5.2 Potential Hydrogen Demand for Synfuel Production Using $\mathrm{CO}_{2}$ from Ethanol, Refinery (SMR $\left.\mathrm{H}_{2}\right)$, and Ammonia ( $\left.\mathrm{NH}_{3}\right)$ Plants

\subsection{Potential Hydrogen Demand for U.S. Methanol Production}

Of the possible synfuels and chemicals that can be synthesized from hydrogen and $\mathrm{CO}_{2}$, $\mathrm{MeOH}$ is expected to see a growth in worldwide demand. Globally, $\mathrm{MeOH}$ is an important feedstock used to produce a range of specialty chemicals used in industry and transportation. Methanol is used as feedstock for derivatives (e.g., formaldehyde and acetic acid), as an end product in transportation (e.g., methyl tert-butyl ether, dimethyl ether, and methanol-to-olefins [MTOs]), in building and construction, and for other uses. The major uses of $\mathrm{MeOH}$ and associated demand shares are shown in Figure 5.3 for years 2010 and 2015 (Alvarado 2016). Compared to the conventional uses for ethanol listed in 2010, the MTO share emerged and increased sharply, reaching $18 \%$ of global use in 2015.

Methanol is commonly produced from several feedstocks such as NG, oil, and renewables, with $\mathrm{NG}$ accounting for approximately $85 \%$ of $\mathrm{MeOH}$ production. Thus, methanol is sensitive to NG price. Methanol is produced from NG via the following chemical reactions:

$$
\begin{aligned}
& \mathrm{CH}_{4}+\mathrm{H}_{2} \mathrm{O} \rightarrow \mathrm{CO}+3 \mathrm{H}_{2} \\
& \mathrm{CO}+\mathrm{H}_{2} \mathrm{O} \rightarrow \mathrm{CO}_{2}+\mathrm{H}_{2} \\
& \mathrm{CO}_{2}+3 \mathrm{H}_{2} \rightarrow \mathrm{CH}_{3} \mathrm{OH}+\mathrm{H}_{2} \mathrm{O}
\end{aligned}
$$




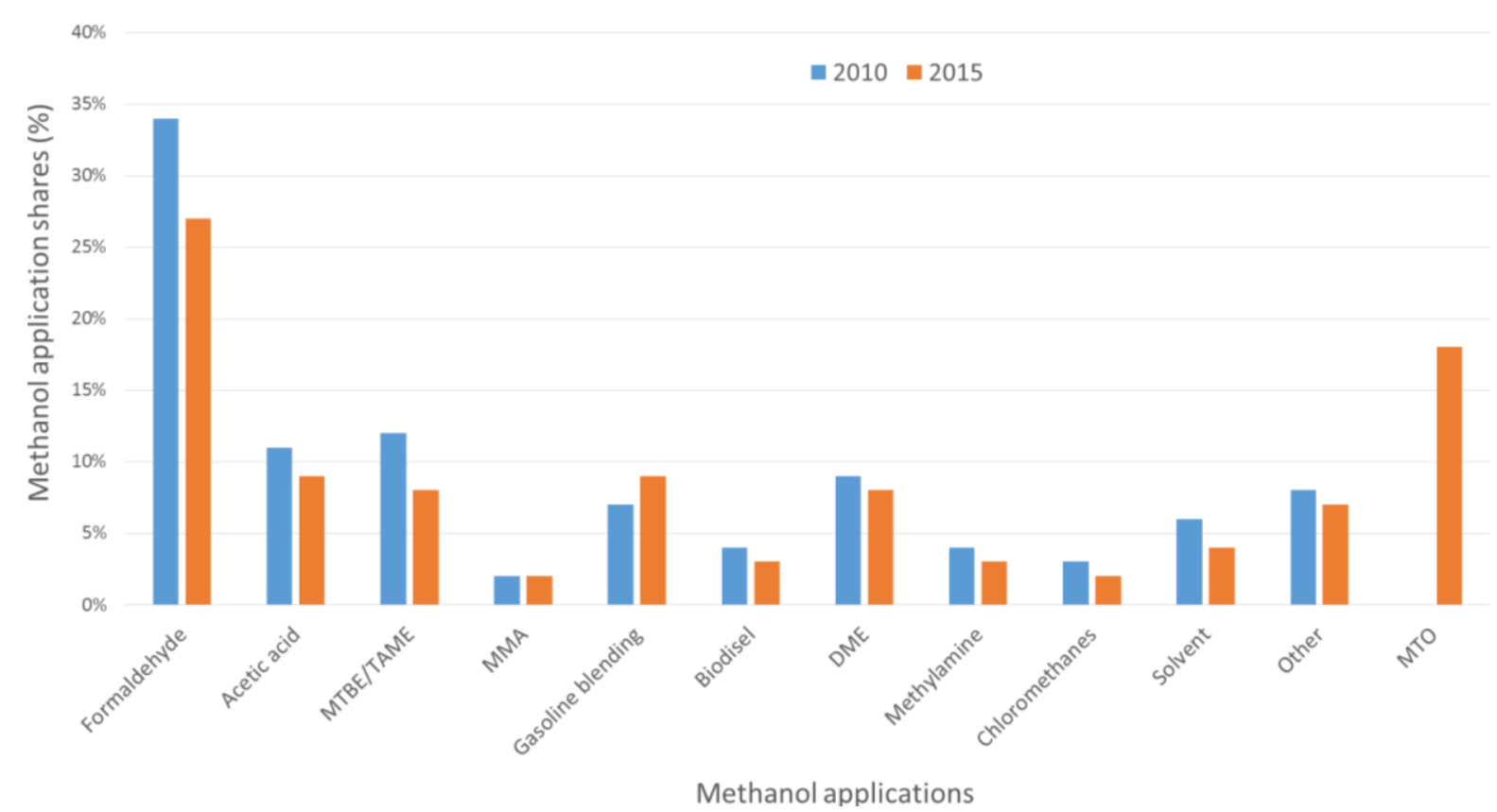

FIGURE 5.3 Global Methanol Applications and Demand Shares in 2010 and 2015 (produced with data from Alvarado 2016) (Note: $M T B E=$ methyl tert-butyl ether, TAME = tert-amyl methyl ether, DME = di-methyl ether, MTO: MeOH-to-olefin)

In the early- to mid-2000s, the high cost of NG in the United States discouraged domestic $\mathrm{MeOH}$ production and led to significant imports, mainly from Trinidad and Tobago and Venezuela (Schneewind 2016). Since 2010, the U.S. shale gas boom significantly suppressed NG price and incentivized domestic $\mathrm{MeOH}$ production. Capacity increases may not only displace imported methanol, but also increase exports to Asian markets by utilizing relatively inexpensive domestic NG (Schneewind 2016). The Asian market is projected to be driven mainly by China, which uses $\mathrm{MeOH}$ derivatives like dimethyl ether (DME), methyl tert-butyl ether (MTBE), and MTO for blending with gasoline (Schneewind 2016; EIA 2017; EIA 2015). In particular, Chinese demand for MTO is projected to be a key driver for $\mathrm{MeOH}$ demand in the coming years.

The EIA (2020) reports that three new plants are expected to come online in 2019 and 2020 with a combined nameplate capacity of about 3.3 MMT annually, thereby increasing total U.S. methanol production capacity by 54\%, for a total capacity of 9.4 MMT, or 25,600 MT per day (Figure 5.4). The United States has planned and announced capacity additions enabling capacity to reach about 25.5 MMT annually by 2030 (Offshore Technology 2019). Most methanol plants are located on the Gulf Coast, where the existing pipeline infrastructure aids distribution. Proximity to the Gulf Coast also allows many of these plants to export methanol to China. 


\section{U.S. methanol plants}

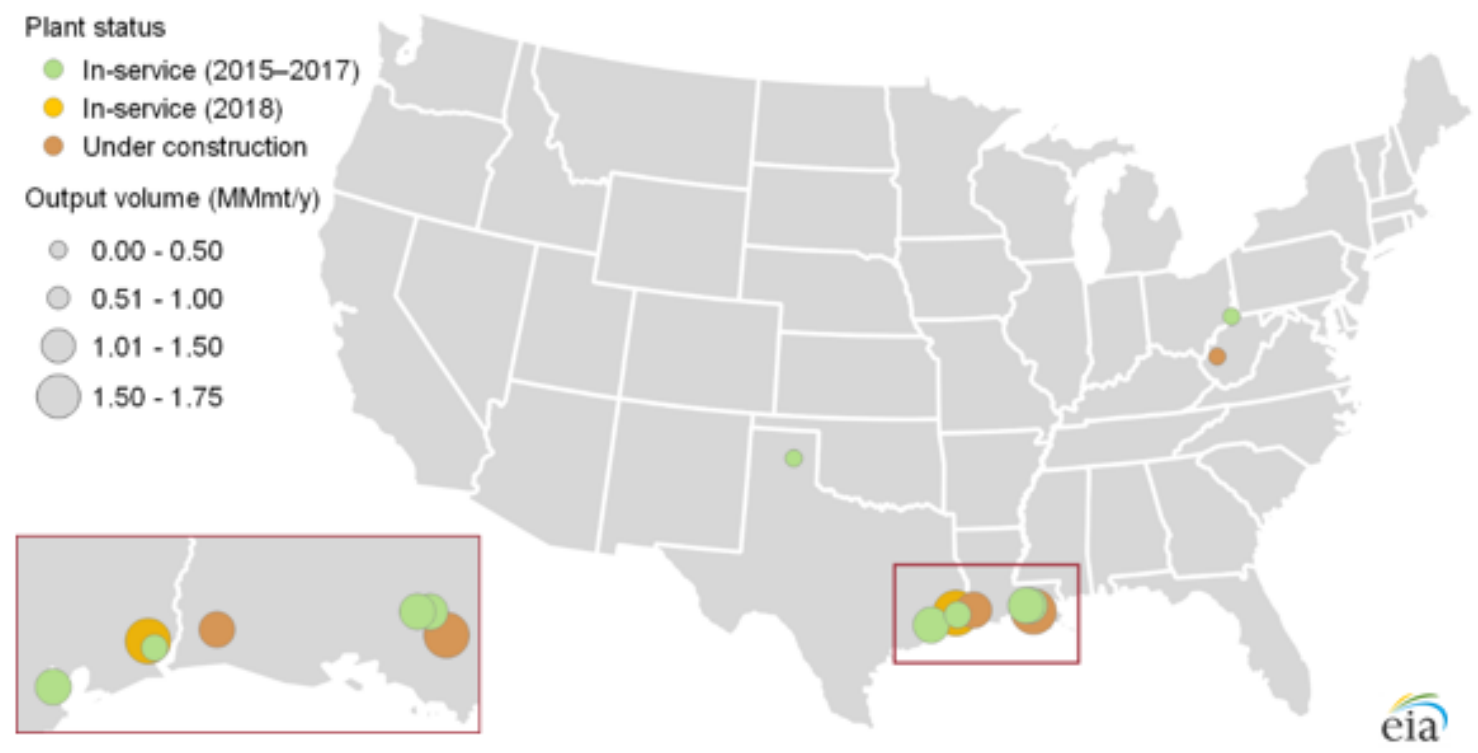

FIGURE 5.4 Current and Under Construction U.S. Methanol Plants (Source: EIA 2020)

Through 2023, methanol demand is expected to grow in the building and construction industry, where formaldehyde-based resins are used to manufacture composites and engineered wood products (Market Research Future 2020). Formaldehyde is also used in interior molded components of vehicles to reduce weight and in personal care products to control bacteria growth (Grand View Research 2019). $\mathrm{MeOH}$ also is increasingly used in the water treatment, plastics, and healthcare industries, and also as a fuel blend in automobiles to improve engine performance and enhance fuel efficiency (Market Research Future 2020).

Estimated U.S. MeOH production and the corresponding potential demand for hydrogen through 2030 are provided in Table 5.1, assuming 3:1 $\mathrm{H}_{2}: \mathrm{CO}_{2}$ mole ratio and $80 \%$ carbon conversion efficiency. If we consider only the high-purity $44 \mathrm{MMT}^{\mathrm{M}} \mathrm{CO}_{2}$ from ethanol plants, annual potential hydrogen demand would be on the order of 6 MMT to produce 25.5 MMT of synthetic methanol. However, if all available $\mathrm{CO}_{2}$ from ethanol, $\mathrm{NH}_{3}$, and $\mathrm{SMR}$ hydrogen plants ( $100 \mathrm{MMT})$, were used to synthesize methanol, potential hydrogen demand could grow to 14 MMT annually, with the potential to produce approximately 57 MMT of methanol. Any excess methanol could be converted to gasoline (MTG) or sold to export markets.

TABLE 5.1 U.S. MeOH Production and Potential Hydrogen and $\mathrm{CO}_{2}$ Demand through 2030

\begin{tabular}{lccc}
\hline & 2018 & 2020 & Total by 2030 \\
\hline & & & \\
MeOH (MMT/year) & 6.1 & 9.4 & 34.9 \\
Hydrogen demand (MMT/year) & 1.4 & 2.2 & 8.2 \\
$\mathrm{CO}_{2}$ demand (MMT/year) & 10.5 & 16 & 60 \\
\hline
\end{tabular}




\subsection{Potential Hydrogen Demand for U.S. Synthetic Fuel and Chemical Production}

The off-road transportation sector accounts for approximately $20 \%$ of U.S. transportation energy consumption and encompasses a broad spectrum of vehicles and equipment serving rail, marine and aviation modes. These applications currently use high-energy-density, fossil-based distillate fuels (e.g., diesel and jet). While these fuels are currently produced from petroleum refining, an alternative approach is to produce them from hydrogen and $\mathrm{CO}_{2}$ feedstock. These "synthetic" fuels could then utilize the same distribution and utilization systems as conventional fossil-based alternatives (e.g., pipelines, tanker trucks, fueling stations, and vehicles). These fuels would also enhance (1) U.S. energy security by reducing dependence on petroleum imports, and (2) air quality by providing ultra-low-S alternatives ( $<1 \mathrm{ppm}$ as compared to low-S petroleum diesel which is $\sim 10 \mathrm{ppm}$ ) with low aromatics content.

In 2017, aviation, marine, and rail modes consumed 2.4, 1.4, and 0.55 quad Btu (high heating value or HHV), respectively, for an annual total of 4.35 quad Btu. This total is estimated to grow to 5.9 quad Btu of mostly distillate fuel by 2050 (EIA 2018). If growth in annual demand for distillate fuel between 2017 and 2050 ( 1.5 quad Btu) were satisfied solely by synthetic FT distillate production, the potential demand for hydrogen could be on the order of 25 MMT in 2050, and could require $230 \mathrm{MMT}$ of $\mathrm{CO}_{2}$ (assuming 2.4:1 $\mathrm{H}_{2} / \mathrm{CO}_{2}$ mole ratio, and $46 \%$ carbon conversion efficiency).

On the other hand, if we assume that synfuel production would be limited to the 44 MMT of high-purity $\mathrm{CO}_{2}$ from ethanol plants, the associated hydrogen demand for synfuel production (based on 2.4:1 $\mathrm{H}_{2} / \mathrm{CO}_{2}$ molar ratio and $46 \%$ carbon conversion efficiency) would be 5 MMT to produce 0.3 quad Btu or 2.3 billion gallons of FT distillate annually. If the $\sim 44$ MMT of high-purity $\mathrm{CO}_{2}$ from ethanol plants were used to produce $25 \mathrm{MMT}$ of synthetic methanol instead of FT diesel, hydrogen demand would be on the order of 6 MMT.

\subsection{Estimates of Threshold Hydrogen Price for Production of Various Synfuels}

On the basis of a literature review and a forthcoming Aspen Plus modeling and supplemental techno-economic analysis, the price point for hydrogen that could enable production of synthetic FT fuel at a cost that is competitive with $\sim \$ 4 / \mathrm{kg}$ petroleum diesel is approximately $\$ 1 / \mathrm{kg}$. For synthetic $\mathrm{MeOH}$ production, the necessary price point for hydrogen is estimated at $\$ 1.73 / \mathrm{kg}$ to be competitive with a methanol price of $\$ 0.5 / \mathrm{kg}$ with a pure $\mathrm{CO}_{2}$ supply (e.g., from ethanol plants). Conventional SMR is the source of hydrogen supply for conventional $\mathrm{MeOH}$ plants. As a result, hydrogen supply at this price point is expected to be viable if waste $\mathrm{CO}_{2}$ is also available nearby at zero cost. However, for less pure sources of $\mathrm{CO}_{2}$ and for new methanol markets (e.g., MTG), the threshold hydrogen price will likely need to be much lower to be competitive with petroleum gasoline. These estimated hydrogen price points are consistent with and calculated in accordance with the methods of Tremel et al. (2015) and de Bucy (2016). 


\subsection{References}

Alvarado, M., 2016. Methanol, IHS presentation, February. Available at http://www.methanol.org/wp-content/uploads/2016/07/Marc-Alvarado-Global-MethanolFebruary-2016-IMPCA-for-upload-to-website.pdf, accessed July 11, 2018.

de Bucy, J., 2016. The Potential of Power-to-Gas, Technology Review and Economic Potential Assessment, Enea Consulting, Paris.

EIA (U.S. Energy Information Administration), 2015. New Methanol and Fertilizer Plants to Increase Already-Growing Industrial Natural Gas Use, July. Available at https://www.eia.gov/todayinenergy/detail.php?id=22272\#, accessed July 11, 2018.

EIA, 2017. China's Use of Methanol in Liquid Fuels Has Grown Rapidly Since 2000, February. Available at https://www.eia.gov/todayinenergy/detail.php?id=30072, accessed July 16, 2018.

EIA, 2018. Petroleum \& Other Liquids: U.S. Fuel Ethanol Plant Production Capacity Archives. Available at https://www.eia.gov/petroleum/ethanolcapacity/archive/2017/index.php, accessed July 12, 2020.

EIA, 2020. New Methanol Plants Expected to Increase Industrial Natural Gas Use through 2020, February 19, 2020. Available at https://www.eia.gov/todayinenergy/detail.php?id=38412\#, accessed March 19, 2020

EPA (U.S. Environmental protection Agency), 2017. Inventory of U.S. Greenhouse Gas Emissions and Sinks 1990-2016, Report EPA 430-R-18-003, Washington, D.C. Available at https://www.epa.gov/sites/production/files/2018-01/documents/2018_complete_report.pdf, accessed July 12, 2020.

Grand View Research, 2019. Methanol Market Size, Share \& Trends Analysis Report By Application (Formaldehyde, Acetic Acid, MTBE, DME, Fuel Blending, MTO, Biodiesel), By Region, and Segment Forecasts, 2019-2025. Available at https://www.grandviewresearch.com/industry-analysis/methanol-market, accessed March 19, 2020.

Market Research Future, 2020. Methanol Market Global Information: by Feedstock (Natural Gas, Oil, and Coal), Derivative (Formaldehyde, Acetic Acid, Dimethyl Ether and Others), EndUse Industry (Transportation, Building and Construction and Others), and Region Forecast till 2023, July. Available at https://www.marketresearchfuture.com/reports/methanol-market-1764, accessed March 19, 2020.

Offshore Technology, 2019. Middle East and North America Lead in Methanol Capacity Additions, GlobalData Energy, July 30. Available at https://www.offshoretechnology.com/comment/global-methanol-capacity/, accessed July 12, 2020. 
Schneewind, J., 2016. US Methanol: Bracing for Growing Pains amid Unprecedented Expansion, Petrochemicals Special Report, May. S\&P Global/Platts.

Supekar, S.D., and S.J. Skerlos, 2014. "Market-Driven Emissions from Recovery of Carbon Dioxide Gas," Environ. Sci. \& Tech., vol. 48(24):14615-14623. DOI:10.1021/es503485z.

Tremel, A., P. Wasserscheid, M. Baldauf, and T. Hammer, 2015. "Techno-Economic Analysis for the Synthesis of Liquid and Gaseous Fuels Based on Hydrogen Production via Electrolysis," Intl. J. Hydrogen Energy, vol. 40:11457-11464. 


\section{INJECTION INTO NG PIPELINES}

The world's first demonstration of at-scale integration of electrolysis-based hydrogen with the electric and natural gas networks occurred in Germany in 2013, when the ITM Power Thüga Group's Power-to-Gas (P2G) plant began operation. The Thüga P2G plant uses a polymer electrolyte membrane electrolyzer to balance load on the grid by generating hydrogen during periods of low electric demand and injecting it into the NG pipeline network at a concentration of about $2 \mathrm{vol} \%$. The injection of low-concentration hydrogen into NG pipelines is currently thought to be feasible without substantial risk of delivering negative impacts to end-use applications (Altfeld and Pinchbeck 2013). It is important to note that the effect of these blends on materials compatibility is still in research stages and must be addressed. However, given R\&D on end-uses and materials compatibility, hydrogen blending into natural gas pipelines could be a viable long-term option. (DOE 2016).

There are two potential options for transporting hydrogen via NG pipelines. One option would be to inject hydrogen into an existing NG pipeline, deliver the mixture a known distance, and then separate the hydrogen from the NG stream via a hydrogen purification method such as pressure swing adsorption or membrane separation. This option is likely costly, owing to the economics of separating low-concentration hydrogen from the mixture stream. Another option would be to inject hydrogen into the NG pipeline network for blending and resale to conventional or dedicated applications as NG with a "renewable" or "zero-carbon" component. The blended NG/hydrogen mix could then be used as a combustion fuel. The value proposition of this approach is challenged by the impact of hydrogen on performance of end uses and pipeline infrastructure, and the differences between hydrogen and natural gas with regard to price and heating value.

Limiting factors or "bottlenecks" that could delay the introduction of hydrogen into the NG system include: (1) the need for improved understanding of the impact of hydrogen blends on pipeline durability (e.g., embrittlement), (2) the need for improved understanding of the impact of hydrogen blends on the durability of natural gas end-use equipment, and (3) regulatory issues, such as the need for creating appropriate specifications and tariffs for hydrogen blends. Resolving these issues will require engaging the R\&D community, key industry stakeholders, and regulatory bodies responsible for oversight, including the U.S. Department of Transportation's Pipeline and Hazardous Materials Safety Administration (PHMSA) and the Federal Energy Regulatory Commission.

In 2017, U.S. consumption of NG was approximately 29 quad Btu or 28 trillion standard $\mathrm{ft}^{3}$. NG consumption is estimated to grow to approximately 36 quad Btu annually or 35 trillion $\mathrm{ft}^{3}$ in 2050 (EIA 2018a). Melaina et al. (2013) concluded that adding hydrogen to existing natural gas pipelines at volume concentrations of 5-15\% are generally acceptable if material and safety issues are addressed, while concentrations of up to $20 \%$ could be acceptable if end-use device limitations are addressed. They also concluded that higher concentrations of hydrogen may be acceptable in transmission lines upstream of distribution lines. In the current study, the maximum potential for hydrogen use in NG pipelines was calculated by assuming that blends are limited to $20 \%$ hydrogen by volume. It is important to note that significant R\&D is 
needed on end-use appliances and materials compatibility to enable blends at such concentrations. Injection of $20 \mathrm{vol} \%$ hydrogen into NG pipelines translates into a potential daily demand of 44,000 MT of hydrogen (or 16 MMT annually) in 2050. It is worth noting that in this simplified calculation, we did not compensate for energy loss resulting from the lower energy content of hydrogen per unit volume as compared to NG. Absent incentives, the cost of hydrogen must compete with that of NG on a heating value basis. EIA (2018b) projects NG prices in 2050 of $\$ 5.88, \$ 6.48$, and $\$ 10.23$ (in 2017 dollars) in per mmBtu (HHV) for industrial use under their Reference, High-Economic-Growth, and Low Oil and Gas Resource cases, respectively. These would require hydrogen prices of $\$ 0.8-\$ 1.4 / \mathrm{kg}$ at end use to be competitive with NG on an HHV basis.

\subsection{References}

Altfeld, K., and D. Pinchbeck, 2013. "Admissible Hydrogen Concentrations in Natural Gas Systems," Gas for Energy, 03, ISSN 2192-158X, DIV Deutscher Industrieverlag GmbH. Available at http://www.gerg.eu/public/uploads/files/publications/GERGpapers/SD_gfe_03_13_Report_Altfe ld-Pinchbeck.pdf., accessed July 12, 2020.

DOE (U.S. Department of Energy), 2016.H2@ Scale (Hydrogen at Scale): Determining Research, Development, and Demonstration (RD\&D) Necessary for Clean Hydrogen Production to Enable Multisectoral Deep Decarbonization, DE-FOA-0001655. Available at https://eereexchange.energy.gov/Default.aspx?Search=DE-FOA-0001655\&SearchType=, accessed July 12, 2020.

EIA (U.S. Energy Information Administration), 2018a. Annual Energy Outlook 2018, Table: Energy Consumption by Sector and Source, Reference Case. Available at https://www.eia.gov/outlooks/aeo/data/browser/\#/?id=2$\underline{\text { AEO2018\&cases }=\text { ref2018\&sourcekey }=0}$, accessed July 12, 2020.

EIA, 2018b. Annual Energy Outlook 2018, Table: Energy Prices by Sector and Source, Reference Case. Available at https://www.eia.gov/outlooks/aeo/data/browser/\#/?id=3$\underline{\mathrm{AEO} 2018 \& \text { cases }=\text { ref2018\&sourcekey }=0}$, accessed July 12, 2020.

Market Screener, 2014. “ITM Power: Thüga Group's Power-to-Gas Plant Officially Commissioned and Operational," May. Available at https://www.marketscreener.com/ITMPOWER-PLC-4004720/news/ITM-Power-Thuga-Group-s-Power-to-Gas-plant-officiallycommissioned-and-operational-30100382/, accessed July 13, 2020.

Melaina, M.W., O. Antonia, and M. Penev, 2013. Blending Hydrogen into Natural Gas Pipeline Networks: A Review of Key Issues, NREL/TP-5600-51995, National Renewable Energy Laboratory, Golden, CO. Available at https://www.nrel.gov/docs/fy13osti/51995.pdf, accessed July 12, 2020. 


\section{STEEL PRODUCTION}

In 2015 and 2017, apparent U.S. steel consumption was 104.6 MMT and 106.2 MMT, respectively. U.S. steel production was 78.8 MMT and 81.6 MMT in those years, while imports were 35.4 MMT and 34.6 MMT, respectively, reflecting $33.8 \%$ and $32.6 \%$ shares of imports in 2015 and 2017, respectively (Global Steel Trade Monitor 2018). Steel is produced in both basic oxygen furnaces and electric arc furnaces. When basic oxygen furnaces are used, $85 \%$ of feedstock is iron and $15 \%$ is scrap metal. When electric arc furnaces are used, scrap metal is the primary feedstock and iron is a secondary feedstock. A growing share of steel is being produced in electric arc furnaces in the United States (World Steel Association 2016; Statista undated; EIA 2016).

Iron is generally produced from the reduction of iron ore. In 2015, the United States produced 43.1 MMT, imported 4.5 MMT, and exported 8.2 MMT of iron ore, reflecting an apparent consumption of 39.4 MMT (World Steel Association 2017). The USGS reported apparent consumption of pig iron at 29.9 MT in 2015, of which 25.4 MMT was produced domestically. Another technology used for iron refining is the direct reduction of iron (DRI). DRI typically utilizes syngas (produced from natural gas) as the reductant, but the process can be modified to use hydrogen blends with syngas. As compared to blast furnace technology, DRI uses less energy for the production of iron. High steel grades are mostly produced from virgin iron through the blast furnace technology. Electric arc furnaces can use both recycled scrap feedstock and direct reduced iron, and commonly use a combination to optimize the quality of the steel produced. For reference, U.S. iron and steel scrap production in 2015 was 74.1 MMT, of which 12.8 MMT was exported, while imports, stocks, and reported consumption were 3.5, 4.4, and 52.5 MMT, respectively (USGS 2017).

Recently, Midrex Technologies, Inc., built a DRI plant in Texas with annual hot briquetted iron (HBI) capacity of 2 million tons, using a syngas mixture of 55\% hydrogen and $36 \% \mathrm{CO}$ (using NG) as the reductant. Midrex is currently building another plant in Ohio with an annual HBI capacity of 1.6 million tons (Chevrier 2018). A similar reduction technology for iron making, developed at the University of Utah, is the flash ironmaking technology (FIT). Using a syngas mixture obtained from NG for FIT can reduce $\mathrm{CO}_{2}$ emissions from iron refining by approximately $35 \%$ compared to iron refining by blast furnace/coke oven technology (Sohn 2016).

The amount of hydrogen needed for the reduction process varies with the degree of hydrogen preheating. Thus, using reaction off-gas to preheat the hydrogen or lowering the reaction temperature decreases the hydrogen requirement (Sohn and Mohassab 2016). The hydrogen mass required to fully reduce $1 \mathrm{MT}$ of iron ore ranges from $0.08 \mathrm{MT}$ to $0.12 \mathrm{MT}$, depending on the technology employed, the reaction temperature, and the reaction off-gas available for hydrogen preheating, assuming no excess hydrogen is needed to overcome the equilibrium of the reduction reaction of magnetite $\left(\mathrm{Fe}_{3} \mathrm{O}_{4}\right)$ and wüstite $(\mathrm{FeO})$ to iron $(\mathrm{Fe})$ (Pinegar et al. 2011). The hydrogen price affects the economic feasibility of FIT more strongly than the capital and operating costs of the technology. An analysis of the sensitivity of net present value (NPV) of FIT to hydrogen prices by Pinegar et al. (2011) concluded that, without 
credits or incentives, the NPV would not be positive even at a hydrogen price of $\$ 1.88 / \mathrm{kg}$ (in 2010 dollars). Extrapolating Pinegar et al.'s (2011) estimates, we estimate that a hydrogen price of $\$ 1.5 / \mathrm{kg}$ (in 2010 dollars, equivalent to $\$ 1.7 / \mathrm{kg}$ in 2017 dollars) would enable positive NPV.

Although DRI in $100 \%$ hydrogen only is possible, a mix of CO or syngas and hydrogen is more economic given that the reduction process in hydrogen is endothermic, whereas the reduction via syngas is exothermic. Furthermore, the addition of carbon to the iron (from the $\mathrm{CO}$ in syngas) reduces its melting temperature and is therefore favorable in steelmaking. Midrex has suggested that replacing up to $30 \%$ of the syngas (by energy) with hydrogen is viable without changing the reduction process (Chevrier 2018).

If current annual imports of $35 \mathrm{MMT}$ of steel were produced domestically via DRI using hydrogen as a reductant, the annual demand for hydrogen for DRI would be on the order of 3.5 MMT, assuming 0.1 MT of hydrogen is required to reduce 1 MT of iron ore (Pinegar et al. 2011). EIA (2016) projects that crude steel production will grow 50\% by 2040, relative to 2015 production. This increase amounts to approximately $120 \mathrm{MMT}$ of U.S. steel production. If all this production were converted to DRI technology, hydrogen demand for steelmaking could range from $4 \mathrm{MMT} / \mathrm{year}$ to $12 \mathrm{MMT} / \mathrm{year}$ depending on whether the reductant would be a $30 \%$ blend of hydrogen with syngas or $100 \%$ hydrogen.

Given the growing share of steel production using electric arc furnaces, we estimate the economic potential for annual hydrogen demand by DRI in 2050 to be 4 MMT/year with hydrogen available at $\$ 1.7 / \mathrm{kg}$, which would yield a positive NPV as noted above. The full annual potential (12 MMT) could be realized if hydrogen were competitive with NG on a thermal heating value basis (i.e., $\$ 0.8 / \mathrm{kg}$, assuming NG for industrial use at $\$ 5.88 / \mathrm{mm}$ Btu [HHV] in 2017 dollars in 2050 under EIA's [2018] Reference case).

\subsection{References}

Chevrier, V., 2018. "Hydrogen Uses in Ironmaking," presented at the H2@ Scale Workshop, Chicago, IL, August 1.

EIA (U.S. Energy Information Administration), 2016. "Changes in Steel Production Reduce Energy Intensity.” Available at https://www.eia.gov/todayinenergy/detail.php?id=27292, accessed July 12, 2020.

EIA, 2018. Annual Energy Outlook 2018. Table: Prices by Sector and Source, Reference Case. Available at https://www.eia.gov/outlooks/aeo/data/browser/\#/?id=3$\underline{\mathrm{AEO} 2018 \& \text { cases }=\text { ref2018\&sourcekey }=0}$, accessed July 12, 2020.

Global Steel Trade Monitor, 2018. Steel Imports Report: United States, International Trade Administration, U.S. Department of Commerce, June. Available at https://www.trade.gov/global-steel-monitor, accessed July 12, 2020. 
Pinegar, H.K., M.S. Moats, and H.Y. Sohn, 2011. "Process Simulation and Economic Feasibility Analysis for a Hydrogen-Based Novel Suspension Ironmaking Technology," Steel Research International, vol. 82(8):951-963. DOI: 10.1002/srin.201000288.

Sohn, H.Y., 2016. "Novel Flash Ironmaking Technology," presented at the H2@Scale Workshop, Golden, CO, November 16.

Sohn, H.Y., and Y. Mohassab, 2016. "Development of a Novel Flash Ironmaking Technology with Greatly Reduced Energy Consumption and $\mathrm{CO}_{2}$ Emissions," Journal of Sustainable Metallurgy, vol. 2(3):216-227. DOI 10.1007/s40831-016-0054-8.

Statista, undated. "Steel Production Figures in the U.S. from 2006 to 2019." Available at https://www.statista.com/statistics/209343/steel-production-in-the-us/, accessed July 12, 2020.

USGS (U.S. Geological Survey), 2017. Iron and Steel Statistics, January.

World Steel Association, 2017. World Steel in Figures. Available at http://orissaminerals.gov.in/Download/World\%20Stee1\%20in\%20Figures\%202017.pdf, accessed July 12, 2020.

World Steel Association, 2016. World Steel in Figures. Available at https://www.worldsteel.org/en/dam/jcr:4f060d8b-3602-4ffe-9e87-

7e93e0659449/Word+Steel+in+Figures+2016.pdf, accessed July 12, 2020. 


\section{LIGHT-DUTY VEHICLE (LDV) APPLICATIONS}

For LDV applications, hydrogen demand depends on the size of the vehicle population into which FCEVs will be introduced and the success of FCEVs in capturing a share of that population, while assuming simultaneous improvements in battery electric vehicle technologies. Each of these factors contains varying degrees of uncertainty, both in how quickly they may evolve, and how external factors (e.g., consumer lifestyles and preferences) might influence them. Forecasts of future hydrogen demand should be based, to the greatest extent possible, on objective, widely accepted trends and projections and on well-vetted tools and techniques. This analysis utilized a vehicle-choice model to estimate the future market penetration of hydrogen fuel cell vehicles, along with estimates of future fuel economy to calculate potential future hydrogen demand. We note that outputs of vehicle-choice models are sensitive to many influencing parameters, including vehicle and fuel cost assumptions, consumer preferences, and the availability of hydrogen fueling station networks, all of which are uncertain. Thus, estimates of vehicle market penetration are inherently uncertain. In addition, we estimated hydrogen demand potentials without considering economics factors, which can be considered an upper bound for the size of the FCEV market, and defined as "serviceable consumption potential".

For this analysis, estimates of FCEV car and light-duty truck (LDT) sales, stock, and hydrogen consumption were developed according to the following process:

- Total FCEV Market Penetration and Sales: FCEV car and LDT sales shares were obtained from prior HFTO analyses consistent with HFTO price targets (Table 2.1) for delivered hydrogen. Annual numbers of FCEVs sold were derived by applying these shares to EIA forecasts of national LDV sales by year.

- Total FCEV Stock and Hydrogen Use: FCEV car and LDT stock, VMT, and hydrogen consumption were estimated by year and summed to produce national totals using Argonne's VISION model (Argonne 2016).

\subsection{Market Penetration and Stock of FCEVs in U.S. LDV Markets}

Market penetration of FCEVs was estimated using the Market Acceptance of Advanced Automotive Technologies (MA3T) vehicle-choice model developed and maintained by Oak Ridge National Laboratory (ORNL undated). MA3T estimates market penetration rates or shares of conventional internal-combustion-engine vehicles (ICEVs), FCEVs, hybrid electric vehicles (HEVs), battery-electric vehicles, and plug-in HEVs PHEVs of different range capabilities (Stephens et al. 2017a). For this analysis, MA3T was run assuming that HFTO's FC and hydrogen fuel cost and performance targets will be met in the future (i.e., the "Program Success" case in HFTO's annual reporting as documented by Stephens et al. [2017b]).

Also, for this analysis, MA3T input costs for all vehicle technologies assumed high manufacturing volumes. The price of hydrogen fuel was assumed to ultimately reach $\$ 5.03 / \mathrm{kg}$ in 2050 , assuming fuel taxes of $\$ 0.53 / \mathrm{kg}$, for consistency with Stephens et al. (2017a). Because 
FCEVs were modeled alongside competing vehicle technologies, results incorporate the effects of different vehicle purchase prices, energy efficiencies, performance attributes, and operating costs on consumer choice under specified hydrogen price assumptions. Table 8.1 contains the price assumptions in 2015 and 2050, which were used to estimate FCEV sales and market share in the discussion that follows.

TABLE 8.1 Assumed Hydrogen Price at Dispenser in 2050

\begin{tabular}{lc}
\hline & 2050 \\
& $(2015 \$ / \mathrm{kg})$ \\
\hline Hydrogen Price at Pump & $\$ 5.03$ \\
\hline
\end{tabular}

FCEV market penetration rates at equilibrium (i.e., where market shares plateau) were $17.8 \%$ of cars and $26.4 \%$ of light trucks. Because these shares reflect market stability, they can also be interpreted as long-run market shares of FCEVs in the car and light truck populations. In order to estimate those populations, an iterative process was employed using EIA (2017) sales projections along with existing vehicle stocks by technology, vintage, and survival rate from the VISION model. The results yielded total projected LDV stocks of 162 million cars and 153 million LDTs, which accounted for 2,465 billion VMT by cars and 1,820 billion VMT by light trucks. Applying the above-noted shares resulted in nearly 28 million fuel cell cars and 40 million fuel cell LDTs at market equilibrium in 2050 (Table 8.2).

TABLE 8.2 FCEV Market Shares and Stock at Market Equilibrium

\begin{tabular}{|r|c|}
\hline \multicolumn{2}{|c|}{ FCEV Market Penetration } \\
\hline Car & $17.8 \%$ \\
\hline LDT & $26.4 \%$ \\
\hline \multicolumn{2}{|c|}{ FCEV Stock $(000)$} \\
\hline Car & 28,000 \\
\hline LDT & 40,000 \\
\hline Total LDV & 68,000 \\
\hline
\end{tabular}

MA3T also produced forecasts of future vehicle stock penetration (at market equilibrium) for cars and LDTs incorporating various other vehicle powertrain technologies. These results are shown in Table 8.3. 
TABLE 8.3 Projected Light-Duty Vehicle Stock Penetration by Powertrain from MA3T

\begin{tabular}{lccccc}
\hline & $\begin{array}{c}\text { Fuel Cell } \\
\text { Electric }\end{array}$ & $\begin{array}{c}\text { Internal Combustion } \\
\text { Engine }^{\mathrm{a}}\end{array}$ & $\begin{array}{c}\text { Hybrid } \\
\text { Electric }\end{array}$ & $\begin{array}{c}\text { Plug-in Hybrid } \\
\text { Electric }\end{array}$ & $\begin{array}{c}\text { Battery } \\
\text { Electric }\end{array}$ \\
\hline Cars & $18 \%$ & $15 \%$ & $10 \%$ & $21 \%$ & $36 \%$ \\
LDTs & $26 \%$ & $11 \%$ & $7 \%$ & $20 \%$ & $36 \%$ \\
\hline
\end{tabular}

a Includes gasoline, diesel, compressed natural gas, and ethanol flex-fuel ICEVs.

\subsection{Total Light-Duty FCEV Hydrogen Use}

As shown in Table 8.4, FCEV average fuel economy increases from $54^{6}$ and 41 miles per gasoline gallon equivalent (mpgge) for cars and light trucks, respectively, in 2015 to 100 and 64 mpgge, respectively, in 2050. FCEVs are assumed to have equivalent fuel economy and to be driven and scrapped (i.e., retired from use) at the same rates as the conventional vehicles they replace. They are also assumed to have the same survival rate and lifetime VMT (about 167,370 miles) as their conventional counterparts. Table 8.4 compares our fuel economy assumptions (in mpgge) for FCEVs with those for comparable ICEVs. Fuel economy for ICEVs also improves between 2015 and 2050, rising from an average of $26 \mathrm{mpg}$ to $43 \mathrm{mpg}$ for ICEV cars, and from $20 \mathrm{mpg}$ to $30 \mathrm{mpg}$ for ICEV light trucks. These fuel economy assumptions are based on Autonomie's vehicle simulation model estimates (which reflect HFTO program goals) for mid-sized cars and mid-sized SUVs, adjusted to on-road values using factors applied in the GREET $^{\circledR}$ model (Argonne 2017). Based on the vehicle stock estimates at market equilibrium in Table 2.2 and vehicle fuel economy estimates in Table 8.4, the future hydrogen consumption by FCEVs was estimated at 4.3 MMT for cars and 7.4 MMT for LDTs, for a total of 11.7 MMT.

\section{TABLE 8.4 On-Road Fuel Economy of FCEV and ICEV Cars and Light Trucks by Model Year}

\begin{tabular}{|c|c|c|c|c|}
\hline \multirow{2}{*}{$\begin{array}{c}\text { Model } \\
\text { Year }\end{array}$} & \multicolumn{2}{|c|}{$\begin{array}{c}\text { Car mpgge } \\
\text { (mi/gasoline gal equivalent) }\end{array}$} & \multicolumn{2}{|c|}{$\begin{array}{c}\text { Light Truck mpgge } \\
\text { (mi/gasoline gal equivalent) }\end{array}$} \\
\hline & Gasoline (E10) ICEV & FCEV & Gasoline (E10) ICEV & FCEV \\
\hline 2015 & 26 & 54 & 20 & 41 \\
\hline 2020 & 31 & 61 & 23 & 45 \\
\hline 2025 & 35 & 72 & 24 & 52 \\
\hline 2030 & 37 & 80 & 25 & 55 \\
\hline 2035 & 39 & 90 & 28 & 58 \\
\hline 2050 & 43 & 100 & 30 & 64 \\
\hline
\end{tabular}

Source: Autonomie (Argonne undated) and GREET (Argonne 2017).

\footnotetext{
${ }^{6}$ Model year 2019 Hyundai Nexo and Toyota Mirai achieve 57 and 67 mpgge on the road, respectively.
} 
We estimate the serviceable consumption potential as the demand if FCEVs constituted $41 \%$ of the LDV fleet in 2050 (i.e., 66 million of 163 million cars and 63 million of 153 million light-duty trucks). We base the fleet penetration on the analysis from Roadmap to a U.S. Hydrogen Economy (2020), which estimates a FCEV sales share of $41 \%$ for passenger vehicles in 2050 using favorable assumptions. The fleet penetration is applied to the $2050 \mathrm{LDV}$ stock to estimate FCEV stock and a corresponding annual hydrogen demand of 21.4 MMT/yr (10.0 $\mathrm{MMT} / \mathrm{yr}$ for cars and 11.4 MMT/yr for light-duty trucks).

\subsection{References}

Argonne (Argonne National Laboratory), 2016. VISION Model, Energy Systems Division. Available at https://www.anl.gov/es/vision-model, accessed July 9, 2020.

Argonne, 2017. "Greenhouse gas, Regulated Emissions and Energy use in Transportation (GREET)," Energy Systems Division, released Oct. 2017. Available at https://greet.es.anl.gov/, accessed April 2018.

Argonne, undated, Autonomie Model, Energy Systems Division. Available at https://www.autonomie.net/, accessed July 9, 2020.

DOE (U.S. Department of Energy), 2018. DOE H2A Analysis. Available at https://www.hydrogen.energy.gov/h2a_analysis.html, accessed July 12, 2020.

EIA (U.S. Energy Information Administration), 2017. Annual Energy Outlook 2017 with Projections to 2050: Reference Case, Washington, D.C.

ORNL (Oak Ridge National Laboratory), undated, MA3T Model. Available at https://www.ornl.gov/content/ma3t-model, accessed July 9, 2020.

"Roadmap to a US Hydrogen Economy," 2020. http://www.fchea.org/us-hydrogen-study, accessed October 2020.

Stephens, T., R. Levinson, A. Brooker, C. Liu, Z. Lin, A. Birkey, and E. Kontou, 2017a. Comparison of Vehicle Choice Models, ANL/ESD-17/19, Argonne National Laboratory, Argonne, IL.

Stephens, T., A. Birkey, and D. Gohlke, 2017b. Vehicle Technologies and Fuel Cell Technologies Office Research and Development Programs: Prospective Benefits Assessment Report for FY 2018, ANL/ESD-17/22, Argonne National Laboratory, Argonne, IL. 


\section{MEDIUM- AND HEAVY-DUTY TRUCK APPLICATIONS}

Medium- and heavy-duty vehicles or MHDVs are used to move freight and provide various services. They encompass a wide range of sizes and body types and operate on a variety of duty cycles. Contractors, construction workers, and delivery services use MD trucks. These vehicles are sometimes called "last-mile" delivery trucks. HD trucks are used for moving heavier and larger cargo within urban areas and over short distances, as well as over long distances. HD trucks used over short distances perform such functions as delivering fuel from terminals, distributing food and other retail items from warehouses/distribution centers, delivering/transporting bulk items in dump trucks, picking up refuse, and moving containers to/from rail yards and ports (drayage).

MHD trucks account for a significant portion (20-25\%) of the energy consumption and air emissions of the U.S. transportation sector. MHDVs, around 11 million trucks and fewer than 1 million buses, represent only $4.5 \%$ of the 260 million vehicles on the road nationally (Argonne 2016). Although they comprise only a small share of the national vehicle population, MHDVs are the second-largest energy consumers and greenhouse gas (GHG) emitters, behind only lightduty vehicles that include passenger cars, sports-utility vehicles, and pickup trucks (DOT 2017, Davis and Boundy 2016, EPA 2016a). Furthermore, MHDVs' energy use is growing faster than any other on- or off-road vehicle segment or transportation mode. Although petroleum accounts for just over half of the total fuel consumed by transit buses (APTA 2016), most MHD trucks still run on petroleum diesel fuel (NRC 2014, EPA 2016b, Davis et al. 2017).

Diesel-powered MHD trucks have a tremendous impact on national and local air pollution. Nationally, MHD diesel trucks account for approximately $30 \%$ of total nitrogen oxides (NOx) and particulate matter $\left(\mathrm{PM}_{2.5}\right.$ and $\left.\mathrm{PM}_{10}\right)$ emissions from mobile sources (EPA 2016b). To improve MHD trucks' energy efficiency and reduce their air emissions, electric vehicle technologies (e.g., battery electric or hydrogen FCEVs) are emerging as viable options. In general, electric trucks have two major advantages over conventional diesel trucks. First, the energy efficiency of an electric powertrain is much higher than that of its diesel counterpart, mostly due to the large heat loss (about $60 \%$ of fuel input) of internal combustion engines (Delorme 2009, DOE 2017). Second, electric trucks create no direct on-road emissions, other than those related to evaporation (e.g., paint) and wear (e.g., tires and brakes). Vehicle electrification, with the advantage of zero tail-pipe emissions, can provide a deep reduction in on-road air emissions from MHD trucks and significantly improve air quality.

Battery electric and hydrogen FCEVs are the two leading MHD truck technologies that are classified as zero-emission vehicles. Like battery electric trucks, hydrogen fuel cell electric trucks (FCETs) create zero tail-pipe emissions and are solely driven by electric motors. California already requires that all transit agencies deploy only zero-emission transit buses starting in 2029 and pending legislation may require zero-emission truck sales for the 2024-2030 model years. Compared to battery electric trucks, FCETs generally have a longer driving range and refuel much more rapidly (requiring only 10-15 minutes to fill empty tanks, i.e., similar to conventional diesel fueling). Compared to battery electric LDVs, fuel cell LDVs generally have 
greater onboard energy storage due to the much lower cost of hydrogen storage relative to the batteries used in comparable plug-in electric vehicles.

On-road MHDVs are subdivided into Classes $2 \mathrm{~b}$ through $8 \mathrm{~b}$ based on gross vehicle weight rating or GVWR (EPA and NHTSA 2016). GVWR is a measure of load-carrying capability, which includes the weight of the vehicle itself (or curb weight) and the maximum payload the vehicle can carry. Class $2 \mathrm{~b}$ includes vehicles with a GVWR between 8,501 and $10,000 \mathrm{lbs}$, mostly larger pickup trucks and vans. Class $8 \mathrm{~b}$ vehicles, with a GVWR above $60,000 \mathrm{lbs}$, are predominantly combination tractor-trailers ("18-wheelers") and are the heaviest vehicles on the road. In the United States, nearly half of MHD trucks are used for urban, local, and short-haul operation, with a daily travel distance less than 200 miles (EPA 2016b). Switching all diesel trucks to FCETs is equivalent to eliminating approximately $30 \%$ of all onroad NOx emissions from the entire MHD truck sector (NREL 2017).

To calculate hydrogen use by FCETs at any given time, three key parameters are required for each vehicle class: (1) number of vehicles on the road, (2) annual VMT, and (3) fuel economy or fuel consumption per mile. Because of the lack of reliable vehicle-choice models for MHDV classes, we assumed the market penetration of fuel cell MHDVs to be consistent with that of fuel cell LDVs in 2050 (i.e., 22\% penetration). Then, we calculated annual sales of MHDVs and, using the VISION model, computed annual vehicle stocks, VMT, and energy use. Note that the Autonomie model (described below) provided the energy efficiency/fuel economy inputs needed for VISION to calculate energy use. Because of the lack of market penetration data for each MHDV class, we used the fuel economies of walk-in trucks and long-haul trucks to represent all MD vehicles and HD vehicles, respectively. Those estimates used the standard method for calculating fuel consumption of MHDV established by the U.S. Environmental Protection Agency (EPA) and National Highway Traffic Safety Administration (NHTSA) (EPA and NHTSA 2016).

\subsection{Vehicle Fuel Economy Modeling}

Although several hydrogen FCET developers (e.g., Kenworth, Toyota, TransPower, US Hybrid) exist in the United States, FCETs are generally in their infancy (mostly custom-built prototypes), and thus only limited real-world vehicles and data are available. Given the early stage of FCET technology and market development, high-fidelity vehicle dynamic simulation provides a good alternative for evaluating vehicles' fuel economy. For vehicle dynamic simulation, this study employed the Autonomie model, one of the most advanced and wellverified vehicle dynamic simulators.

The U.S. Department of Energy has developed fuel economy targets for future long-haul diesel and fuel cell electric HD trucks. ${ }^{7}$ These targets assume possible technological advancements in key factors that impact the vehicle's fuel economy, such as powertrain efficiency, vehicle lightweighting, hybridization, and improved aerodynamics and rolling resistance. In setting those targets, DOE employed the Autonomie model to evaluate technology

${ }^{7}$ https://www.hydrogen.energy.gov/program records.html, accessed July 10, 2020. 
pathways of individual components in fuel cell long-haul HD vehicles that could achieve market competitiveness with diesel trucks on a life cycle cost basis. Because a rigorous fuel economy target for MD fuel cell vehicles (i.e., Classes $2 b-6$ ) is yet to be developed, we utilized comparable Autonomie model simulations to estimate the fuel economy of those vehicles. Note that Autonomie-simulated fuel consumption estimates used Phase 2 EPA/NHTSA fuel efficiency and GHG emission standards for MHDVs (EPA 2016c), along with weighting factors for computing average fuel consumption on three driving cycles (a transient cycle developed by California's Air Resources Board, a 55-mph cruise cycle, and a 65-mph cruise cycle), to which fuel consumption related to idling activities was added after weighting.

Because vehicular energy consumption can be significantly affected by vehicle design attributes and performance criteria (e.g., vehicle test weight, frontal area, maximum acceleration, rated power), it is important that such parameters be representative of real-world data. Thus, vehicle components were sized based on truck market information and in-use truck activity data from Fleet DNA (NREL 2017) and the Vehicle Inventory and Use Survey (DOC 2004). The method and data sources used for component sizing are described in detail by Vijayagopal (2016) and Kast et al. (2017). Table 9.1 shows the key parameters and weighting strategy used to estimate composite fuel economy for the representative MD and HD truck Classes (i.e., walk-in trucks and long-haul trucks) for 2050.

\subsection{Potential Hydrogen Demand by Medium- and Heavy-Duty Fuel Cell Vehicles}

As shown in Table 9.1, composite fuel economies of 33.0 and $14.7 \mathrm{mi} / \mathrm{kg}_{\mathrm{H} 2}$ were estimated for Class 4 walk-in delivery trucks and Class 8 long-haul sleeper-cab trucks, respectively. Using the VISION model, total annual VMT for all MDVs (Classes 2b-6) and HDVs (Classes 7-8) in 2050 were estimated at 212 billion and 252 billion for MDVs and HDVs, respectively.

The above estimates of fuel economy and total annual VMT, along with the $22 \%$ penetration of FCEVs into the MHDV sector, resulted in potential hydrogen consumption of 1.4 and 3.8 MMT by MD and HD fuel cell trucks, respectively. For the entire MHDV sector, total hydrogen demand was estimated to reach 5.2 MMT in 2050.

TABLE 9.1 Parameters Relating to Fuel Efficiency of MHD Fuel Cell Trucks

\begin{tabular}{|c|c|c|c|c|}
\hline Test Vehicle & GVWR Class & $\begin{array}{c}\text { Vehicle's Payload } \\
\text { (tonnes) }\end{array}$ & $\begin{array}{l}\text { Weighting Strategy for } \\
\text { Computing Efficiency }\end{array}$ & $\begin{array}{c}\text { Composite Fuel } \\
\text { Economy }\left(\mathrm{mi} / \mathrm{kg}_{\mathrm{H} 2}\right)\end{array}$ \\
\hline Walk-in Truck ${ }^{\mathrm{a}}$ & 4 & 3.64 & Urban drive cycle $^{\mathrm{b}}$ & $33.0^{\mathrm{c}}$ \\
\hline Long-haul Truck ${ }^{\mathrm{d}}$ & $8^{\mathrm{b}}$ & 16.3 & EPA 55 drive cycle & 14.7 \\
\hline \multicolumn{5}{|c|}{$\begin{array}{l}\text { Based on Autonomie simulations of fuel consumption and EPA/NHTSA driving cycles. Fuel consumption is the inverse of fuel } \\
\text { economy. } \\
\text { b Defined in the EPA and NHTSA (2016) standards. } \\
\text { c Weighted fuel economy for urban drive cycle based on } 92 \% \text { transient driving }(39.0 \mathrm{mi} / \mathrm{kgH} 2) \text { and } 8 \% \text { highway cruise at } 55 \mathrm{mph} \\
\left(25.1 \mathrm{mi} / \mathrm{kgH}_{\mathrm{H}}\right) \text {. } \\
\text { d Fuel economy for EPA } 55 \mathrm{mph} \text { drive cycle based on DOE target fuel economy for fuel cell long-haul trucks. }\end{array}$} \\
\hline
\end{tabular}


We estimate the serviceable consumption potential of the MDV and HDV hydrogen market as equivalent to the hydrogen required if $35 \%$ of the fleet operated on hydrogen, based on the 2050 sales share estimate from Roadmap to a U.S. Hydrogen Economy (2020), which uses favorable assumptions for FCEVs. Applying this market penetration to the vehicle stock results in 4.2 million FCEVs of a 12 million MDV stock and 2.0 million FCEVs of a 5.7 million HDV stock in 2050 . The corresponding annual hydrogen demand is estimated at $8.2 \mathrm{MMT} / \mathrm{yr}$ (2.2 $\mathrm{MMT} / \mathrm{yr}$ for MDVs and 6.0 MMT/yr for HDVs).

\subsection{References}

APTA (American Public Transportation Association), 2016. 2016 Public Transportation Fact Book, Washington, D.C., April.

Argonne (Argonne National Laboratory), 2016. VISION Model, Energy Systems Division. Available at https://www.anl.gov/es/vision-model, accessed July 9, 2020.

Davis, S.C., and R.G. Boundy, 2016. Transportation Energy Data Book, Edition 38, Oak Ridge National Laboratory, October. Available at http://cta.ornl.gov/data/index.shtml, accessed July 10, 2020 .

Davis, S.C., S.E. Williams, R.G. Boundy, and S. Moore, 2017. 2016 Vehicle Technologies Market Report, "Chapter 4: Heavy Trucks," Oak Ridge National Laboratory, ORNL/TM$2017 / 238$.

Delorme, A., D. Karbowski, R. Vijayagopal, and P. Sharer, 2009. Evaluation of Fuel Consumption Potential of Medium and Heavy Duty Vehicles through Modeling and Simulation, Report to National Academy of Sciences, Argonne National Laboratory, October 23.

DOC (U.S. Department of Commerce), 2004. Vehicle Inventory and Use Survey, U.S. Census Bureau. Available at https://www.census.gov/library/publications/2002/econ/census/vehicleinventory-and-use-survey.html, accessed July 10, 2020.

DOE (U.S. Department of Energy), 2017. Where the Energy Goes: Electric Cars. Available at https://www.fueleconomy.gov/feg/atv-ev.shtml, accessed July 10, 2020.

DOT (U.S. Department of Transportation), 2017. National Transportation Statistics, Bureau of Transportation Statistics. Available at https://www.bts.gov/national-transportation-statistics2017-4th-quarter, accessed July 10, 2020.

EPA (U.S. Environmental Protection Agency), 2016a. Inventory of U.S. Greenhouse Gas Emissions and Sinks: 1990-2014. Available at https://www.epa.gov/ghgemissions/inventory-usgreenhouse-gas-emissions-and-sinks, accessed July 10, 2020.

EPA, 2016b. 2014 National Emissions Inventory. Available at https://www.epa.gov/airemissions-inventories/national-emissions-inventory-nei, accessed July 10, 2020. 
EPA (U.S. Environmental Protection Agency), 2016c. MOtor Vehicle Emission Simulator (MOVES). Available at https://www.epa.gov/moves/moves2014a-latest-version-motor-vehicleemission-simulator-moves, accessed July 10, 2020.

EPA and NHTSA (National Highway Traffic Safety Administration), 2016. "Greenhouse Gas Emissions and Fuel Efficiency Standards for Medium- and Heavy-Duty Engines and Vehicles Phase 2; Final Rule," Federal Register, 81(206):73478-74274, October 25, Rules and Regulations.

Kast, J., R. Vijayagopal, J.J. Gangloff, Jr., and J. Marcinkoski, 2017. "Clean Commercial Transportation: Medium and Heavy Duty Fuel Cell Electric Trucks," Intl. J. of Hydrogen Energy, 42(7), 4508-4517. doi:10.1016/j.ijhydene.2016.12.129.

NRC (National Research Council of the National Academies), 2014. Reducing the Fuel Consumption and Greenhouse Gas Emissions of Medium- and Heavy-Duty Vehicles, Phase Two: First Report, Committee on Assessment of Technologies and Approaches for Reducing the Fuel Consumption of Medium- and Heavy-Duty Vehicles, Phase Two, Board on Energy and Environmental Systems, Division on Engineering and Physical Sciences, Transportation Research Board, ISBN 978-0-309-30237-1.

NREL (National Renewable Energy Laboratory), 2017. Fleet DNA: Commercial Fleet Vehicle Operating Data. Available at www.nrel.gov/fleetdna, accessed July 10, 2020.

"Roadmap to a US Hydrogen Economy," 2020. http://www.fchea.org/us-hydrogen-study, accessed October 2020.

Vijayagopal, R., 2016. Fuel Cell Electric Truck (FCET) Component Sizing. FY 2016 Annual Progress Report, U.S. Department of Energy Hydrogen and Fuel Cells Program, DOE/GO102017-4891, February 2017. Available at https://www.hydrogen.energy.gov/pdfs/progress16/ vii_a_3_vijayagopal_2016.pdf, accessed July 10, 2020. 



\section{Argonne}

\section{Energy Systems Division}

Argonne National Laboratory

9700 South Cass Avenue, Bldg. 362

Lemont, IL 60439-4832

www.anl.gov 